\author{
UNIVERSIDADE DE SÃO PAULO \\ ESCOLA DE ARTES, CIÊNCIAS E HUMANIDADES \\ Programa de Pós-graduação ProMuSPP
}

SANDRA PAULA DA SILVA BATISTÃO

EDUCAÇÃO INCLUSIVA OU EDUCAÇÃO PARA TODOS? CONTRIBUIÇÕES DA TEORIA HISTÓRICO-CULTURAL PARA UMA ANÁLISE CRÍTICA DA REALIDADE ESCOLAR 
SANDRA PAULA DA SILVA BATISTÃO

\section{EDUCAÇÃO INCLUSIVA OU EDUCAÇÃO PARA TODOS? CONTRIBUIÇÕES DA TEORIA HISTÓRICO-CULTURAL PARA UMA ANÁLISE CRÍTICA DA REALIDADE ESCOLAR.}

Dissertação apresentada ao Programa de PósGraduação em Mudança Social e Participação Política, para obtenção do título de Mestre em Ciências.

Orientadora: $\operatorname{Prof}^{\mathrm{a}} \operatorname{Dr}^{\mathrm{a}}$ Maria Eliza Mattosinho Bernardes

Versão corrigida. Original encontra-se na unidade que aloja o Programa.

São Paulo

2013 
Autorizo a reprodução e divulgação total ou parcial deste trabalho, por qualquer meio convencional ou eletrônico, para fins de estudo e pesquisa, desde que citada a fonte.

\section{CATALOGAÇÃO-NA-PUBLICAÇ̃̃O \\ Biblioteca}

Escola de Artes, Ciências e Humanidades da Universidade de São Paulo

Batistão, Sandra Paula da Silva

Educação inclusiva ou educação para todos? : contribuições da teoria histórico-cultural para uma análise crítica da realidade escolar / Sandra

Paula da Silva Batistão; orientadora, Maria Eliza Mattosinho Bernardes.

- São Paulo, 2013.

$147 \mathrm{f}$.

Dissertação (Mestrado em Ciências) - Programa de Pós-

Graduação em Mudança Social e Participação Política, Escola de

Artes, Ciências e Humanidades da Universidade de São Paulo.

Versão corrigida.

1. Educação especial. 2. Educação inclusiva. 3. Política educacional. 4. Administração pública. 5. Políticas públicas. I. Bernardes, Maria Eliza Mattosinho, orient. II. Título. 


\title{
EDUCAÇÃO INCLUSIVA OU EDUCAÇÃO PARA TODOS? CONTRIBUIÇÕES DA TEORIA HISTÓRICO-CULTURAL PARA UMA ANÁLISE CRÍTICA DA REALIDADE ESCOLAR.
}

\author{
SANDRA PAULA DA SILVA BATISTÃO
}

Dissertação apresentada ao Programa de PósGraduação em Mudança Social e Participação Política, para obtenção do título de Mestre em Ciências.

Banca examinadora:

$\overline{\text { Membro titular: } \text { Prof }^{\mathrm{a}} \text { Dr }^{\mathrm{a}} \text { Maria Eliza Mattosinho Bernardes }}$

Membro titular: Prof ${ }^{\mathrm{a}}$ Dr $^{\mathrm{a}}$ Maria Isabel Batista Serrão

Membro titular: Prof $^{\circ}$ Dr $^{\circ}$ Vanderlei Elias Nery

Dissertação defendida e aprovada em: 03/07/2013 
O Guardador de Rebanhos (Canto XXXIX)

O mistério das coisas, onde está ele?

Onde está ele que não aparece

Pelo menos a mostrar-nos que é mistério?

Que sabe o rio disso e que sabe a árvore?

E eu, que não sou mais do que eles, que sei disso?

Sempre que olho para as coisas e penso no que os homens pensam delas,

Rio como um regato que soa fresco numa pedra.

Porque o único sentido oculto das coisas

É elas não terem sentido oculto nenhum, É mais estranho do que todas as estranhezas

E do que os sonhos de todos os poetas

E os pensamentos de todos os filósofos,

Que as coisas sejam realmente o que parecem ser

E não haja nada que compreender.

Sim, eis o que os meus sentidos aprenderam sozinhos:

As coisas não têm significação: têm existência.

As coisas são o único sentido oculto das coisas 
Ao Cezar e à Marina, meus amores, com orgulho e gratidão por estarem sempre presentes e por fazerem minha vida mais bela.

Á todos os alunos que acompanhei durante a assessoria, não posso desistir de intencioná-los uma escola mais justa. Agradeço a dois alunos em especial: Satoru e Matheus, pois suas demandas, desafios e alegrias projetaram-me na busca do conhecimento sobre a Educação Especial e a Educação Inclusiva. Sou grata por terem feito parte da minha história e por eles não posso deixar de sonhar uma sociedade que os inclua verdadeiramente. 


\section{AGRADECIMENTOS}

À Deus, em quem sempre confiei e de quem recebi força e sabedoria para lidar com o que surgia inesperada e dolorosamente durante o percurso do mestrado...

À Escola de Artes, Ciências e Humanidades da Universidade de São Paulo pela oportunidade de ser INCLUÍDA como aluna no curso Mudança Social e Participação Política; oportunidade da qual tenho imenso orgulho;

Aos funcionários da EACH. Todos contribuíram de alguma forma para a realização desta dissertação e certamente de outras, pois no exercício de suas funções tornam a faculdade um espaço de agradável convivência.

Aos secretários da pós-graduação, em especial a Jussara Barbosa que sempre com carinho e dedicação direcionava minhas solicitações;

Aos colegas de classe, posto que o compartilhamento de ideias foi necessário e intenso. Os diferentes olhares e concepções sobre as diferentes áreas do conhecimento movimentaram reflexões sobre a necessidade de Mudança Social e Participação Política;

Especialmente sou grata a minha orientadora, Prof ${ }^{a}$ Dra $^{a}$ Maria Eliza Mattosinho Bernardes que confiou em minha capacidade e me proporcionou o encontro com a teoria que norteia esta pesquisa. Agradeço sua disponibilidade, rigorosidade e sua oferta generosa de conhecimento científico. Seus ensinamentos e orientações foram essenciais na realização deste trabalho;

Aos colegas do GEPESPP - Grupo de Estudos e Pesquisas Educação, Sociedade Políticas Públicas: concepções da teoria histórico-cultural que me fizeram compreender a importância da coletividade de estudos na formação profissional. Em especial agradeço a Sandra Assali quando nos momentos de dúvidas e dificuldades me oferecia escuta atenciosa e problematizadora;

Aos professores participantes da banca da qualificação, $\operatorname{Prof}^{0} \operatorname{Dr}^{0}$ Diamantino e $\operatorname{Prof}^{a}$ $\operatorname{Dr}^{\mathrm{a}}$ Isabel Serrão. Especialmente a esta última que com generosidade me conduziu para além do que naquele momento eu sozinha poderia compreender;

Á Prof $f^{a}$ Dra ${ }^{a}$ Elenita Tanamachi e ao $\operatorname{Prof}^{\circ} \operatorname{Dr}^{\circ}$ Vanderlei Nery pela leitura do texto e pelos apontamentos que me conduziram à busca do desvelamento do que se apresentava a mim no cotidiano da escola;

À Liliane Garcez que generosamente realizou a leitura crítica do trabalho e durante os cafés pedagógicos reforçou minha compreensão de que ensinar e aprender é movimento de mão dupla;

Às diretoras e vices, assistentes pedagógicas, professoras assessoradas e a todos os demais sujeitos das escolas da rede municipal de ensino de Santo André com os quais atuei. Em parceria compartilhamos sentimentos de estranhezas, certezas e incertezas, tristezas e alegrias. Juntos, desfrutamos conquistas, expectativas e inquietações frente às demandas dos alunos com e sem deficiência. Sem dúvida alguma, aprendemos juntos! 
Agradecimento especial à professora participante desta pesquisa. Ao longo dos nossos encontros, "Ana" me fez ampliar a percepção de que a parceria, o debate e a compreensão sobre a função social que assumimos é fundamental frente à tentativa de construção de uma escola verdadeiramente inclusiva.

Á Ester Asevedo e Ayeres Brandão, pelos ensinamentos e demonstrações de confiança no meu trabalho. Sabemos o quanto lutamos por uma escola de qualidade para nossos alunos e professores.

Á equipe do CADE. Todos foram lembrados durante a produção desta pesquisa. Sem exceção, todos contribuíram... Toninho, Lilian, Lidia, Maria Helena, Héride, Tânia, Alissandra, Regininha, Rosane, Anas, Angela, Edméia, Milza, Renata, Roses, Denise, Deise, Sandras e Simara, Tatiane, Viviane, Agda, Maraligia, Carla, Claudia, Celeste, Edmara e Mara, Edna e Eliana, Lucia, Mary, Neiva, Silvia e Silvio, Solange, Priscila e Fabiana. Juntos, no exercício de nossas funções, colaboramos para que os alunos com deficiência pudessem (além do acesso e da permanência) participar de uma escola verdadeiramente inclusiva... sonho compartilhado por todos nós. Especialmente agradeço a Tania de Souza pela alegria contagiante e pela presença constante (durante o percurso da pesquisa) através das mensagens, telefonemas e rápidos encontros para um café;

Á Dalva Elizabete... agradeço o carinho, a amizade verdadeira e o incentivo;

Agradeço o carinho das agentes Sociais de Inclusão; em especial, Zilca Anita, Rita Coradello e Maria José. Juntas pudemos confidenciar dissabores, compartilhar conquistas e comemorar o avanço dos alunos que acompanhávamos;

Agradeço ao meu pai Paulo, o qual me ensinou desde muito cedo que conhecimento é fundamental. Os livros presenteados na infância marcaram minha trajetória transportando-me para outros mundos. Com ele aprendi que os livros têm este poder;

Aos meus queridos irmãos Israel, Simone e Solange, agradeço pela existência e amizade. Ás minhas irmãs, agradeço os sobrinhos lindos que tanto amo. Todos são parte de mim e sei que posso contar;

Ao Cezar e a Marina. Ao Cezar agradeço pelos olhares carinhosamente direcionados durante a produção do texto sinalizando silenciosamente seu apoio. À Marina agradeço pelo incentivo para começar esse mestrado e pelas leituras realizadas durante o mesmo. Agradeço pelo seu encorajamento durante todo o percurso e pelo apoio incondicional. Nós duas sabemos que nossa opção de ser professora nos causa orgulho... Aos dois agradeço por serem meus filhos;

À Biba, pela lealdade e pela presença carinhosa e calorosa durante todo momento de produção e estudo;

Ao Lico, companheiro presente desde o projeto inicial até o término desta dissertação, agradeço a compreensão do meu distanciamento e o fato de ter assumido cuidadosamente algumas de minhas responsabilidades, colaborando, desta maneira, para que eu pudesse me dedicar a pesquisa em questão. Juntos construímos um longo e belo percurso... 


\title{
BATISTÃO, S. P. Educação Inclusiva ou Educação para todos? Contribuições da teoria
}

histórico-cultural para uma análise crítica da realidade escolar. Dissertação (mestrado).

Escola de Artes, Ciências e Humanidades da Universidade de São Paulo, 2013.

\begin{abstract}
RESUMO
Esta pesquisa tem como objetivo analisar os limites e as possibilidades da educação inclusiva a partir da gestão de política pública para o exercício da ação pedagógica do professor e do professor assessor frente à proposta de um contexto educacional com a finalidade de identificar caminhos que possam compor para o processo de superação do que está instituído no cotidiano escolar. Durante o movimento de investigação os conceitos de Estado, Educação, Educação Inclusiva e Necessidades Educacionais Especiais são tratados a partir dos pressupostos da pedagogia histórico-crítica e da psicologia histórico-cultual estabelecendo relações entre a ação pedagógica de todos os sujeitos da educação e o exercício de suas funções. A unidade de análise na pesquisa é a relação entre a gestão de política de Estado no campo da Educação e todos os envolvidos na construção do processo educacional inclusivo, destacando a função social do professor, do professor assessor e da equipe escolar quando estes, no cotidiano da escola, deparam-se com alunos com diagnóstico de dificuldades de aprendizagem e ou deficiência. Sabe-se que muito tem sido discutido sobre a escola inclusiva como sendo aquela que matricula alunos com deficiência na sala regular de ensino, no entanto, esta pesquisa propõe problematizar não somente a inclusão educacional do aluno com deficiência ou do aluno com dificuldades de aprendizagem, mas a inclusão através da mediação do conhecimento científico como aquele que deve ser oportunizado para todos os alunos da escola pública. Reafirmando o direito de todos à educação, abordam-se os impactos causados pelos alunos com dificuldades de aprendizagem, quando estes, muitas vezes sentemse solitários na escola, que se intitulando inclusiva frente aos alunos com deficiência, não assume a diversidade, o conhecimento científico e seus desdobramentos como sendo o ponto central de transformação de uma escola excludente e seletiva em uma escola inclusiva. Entende-se que, apesar das tentativas de construção de uma escola inclusiva de qualidade, muitas são as situações de exclusão escolar na sociedade contemporânea. Sendo assim, essa pesquisa analisa os processos de inclusão e exclusão enquanto produção social, dos quais fazem parte tanto os alunos quanto seus professores. Essa pesquisa, portanto, é composta por um processo de investigação bibliográfica concomitante ao processo de investigação empírica sobre o cotidiano da assessoria em uma escola municipal da cidade de Santo André. Para análise dos dados busca-se compreender o contexto empírico a partir das seguintes categorias: dimensão tarefeira na ação pedagógica, a imediaticidade na realidade concreta e a governança do tempo e do espaço no conjunto das ações presentes na educação inclusiva. Os resultados encontrados na pesquisa possibilitam a proposição de um conjunto de elementos apontando estes como necessidades a serem viabilizadas pela gestão de política pública local de forma a garantir reais condições para o exercício de uma educação que pretende ser inclusiva.
\end{abstract}

Palavras chaves: Políticas de Estado, Educação, Educação Inclusiva. 


\title{
BATISTÃO, S. P. Inclusive Education or Education for All? Contributions from
} cultural-historical theory to a critical analysis of school reality. Dissertação (mestrado).

Escola de Artes, Ciências e Humanidades da Universidade de São Paulo, 2013.

\begin{abstract}
This research investigates the limits and possibilities from the management of public policy for the exercise of teacher pedagogical action and the adviser teacher forward the proposal of an inclusive educational context in the objectification of finding ways to indicate requirements that may compose with overcoming what is established in the educational routine. During the course of investigation the concepts of State, Education, Inclusive Education and Special Educational Needs are dealt from the assumptions of the historicalcritical pedagogy and psychology historical and cultic establishing relations with the pedagogical action of all subjects of education in exercise their functions. The paper analyzes the relationship between management and public policy all involved in the construction process of inclusive education, highlighting the social role of the teacher and teacher's aide, and its educational activities, when they, in everyday school face with students with diagnosis of difficulties to learn and or disabilities. We know that much has been discussed about the inclusive school as one that enrolls students with disabilities in regular classroom teaching, however, this research proposes to analyze not only the educational inclusion of students with disabilities or students with learning difficulties, but the inclusion through the mediation of scientific knowledge as one that should be offered for all public school students. Reaffirming the right of everyone to education, addressing the impacts caused by students with learning difficulties, when they often feel lonely in this school, which is inclusive titling against students with disabilities, assumes no diversity, scientific knowledge and its development as the central point of transformation from a selective and exclusionary school in an inclusive school. It is understood that, despite attempts to build an inclusive school quality, there are many situations of school exclusion in contemporary society. Therefore, this research examines the processes of inclusion and exclusion as social production, which belong to both the students and their teachers. This research, therefore, is composed of a process of research literature accompanying the process of empirical research on the daily advice in a public school in the city of Santo André. Data analysis seeks to understand the empirical context from the following categories: dimension execution in pedagogical action, the immediacy and governance in reality time and space in all of the shares present in inclusive education. The findings of the survey allow the proposition of a set of elements such as pointing needs to be made available by the management of local public policy to ensure real conditions for the exercise of an education that aims to be inclusive.
\end{abstract}

Keywords: State Policies, Education, Inclusive Education. 


\section{Lista de quadros e figuras}

Quadro 01: Síntese do movimento dos eixos de análise no contexto educacional inclusivo.

Figura 01: Registro das ações pedagógicas realizado pela P.A.E.I................................ 105

Quadro 02: Movimento de Análise na Realidade Concreta.........................................110

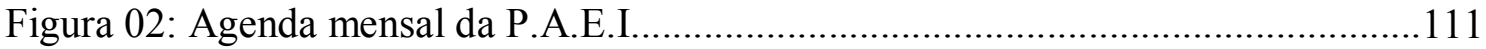

Figura 03: Pauta da reunião da equipe do CADE.......................................................... 112

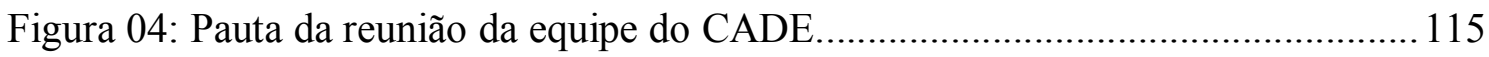

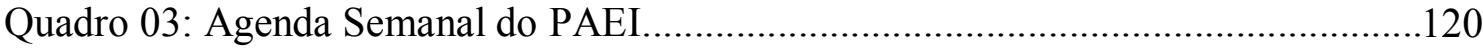

Figura 05: Avaliação sobre o CADE realizado pela professora assessorada..................125

Figura 06: Registro do planejamento pedagógico da assessoria no movimento da pesquisa.

Figura 07: Registro do planejamento pedagógico da assessoria no movimento da pesquisa. 


\section{SUMÁRIO}

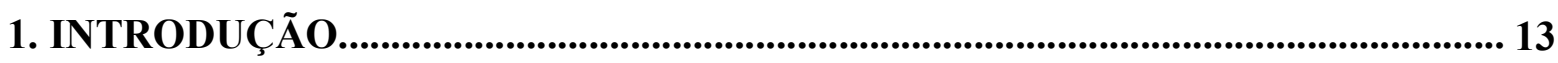

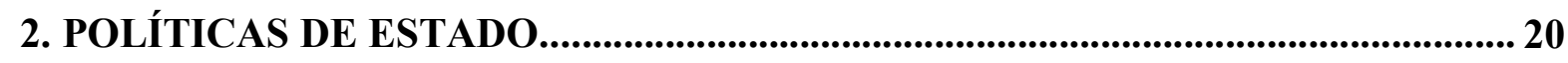

2.1 Educação em geral...............................................................................................................221

2.2 O papel do Estado na Educação................................................................................ 22

2.3 Educação Pública e Educação Escolar...................................................................... 25

2.4 Constituição de 1998 e LDB: desdobramentos Educacionais............................... 31

2.5 Educação Especial: Atendimento Educacional Especializado................................. 41

3. EDUCAÇÃO INCLUSIVA OU EDUCAÇÃO PARA TODOS?................................. 48

3.1 Inclusão e exclusão como produção social..............................................................49

3.2 A Declaração de Salamanca e os Princípios Educacionais Inclusivos................... 57

3.3 A Educação no Município de Santo André: processo de municipalização do ensino e seu percurso histórico...........................................................................................63 63

3.4 CADE - Centro de Atenção ao Desenvolvimento Educacional...........................69

4. A INVESTIGAÇÃO NA REALIDADE DA EDUCAÇÃO INCLUSIVA..................88

4.1. A realidade concreta e os sujeitos no movimento da pesquisa..............................8 89

4.2 Etapa da Ação Pedagógica Reiterativa....................................................................... 100

4.2.1 Etapa da Ação Pedagógica Reelaborada...................................................................103

4.3 Procedimentos Análiticos..........................................................................107

4.3.1 Governança do Tempo e do Espaço......................................................................... 110

4.3.2 Imediaticidade das Necessidades na Realidade Concreta............................... 117

4.3.3 Dimensão Tarefeira na Ação Pedagógica..............................................................123

5. CONSIDERAÇÕES FINAIS..............................................................................................130

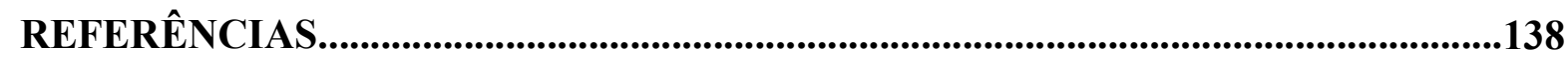

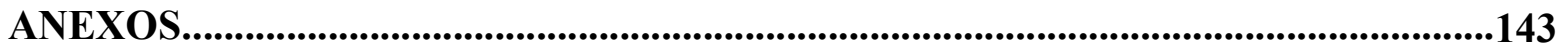




\section{INTRODUÇÃO}

\section{Educação Inclusiva ou Educação para Todos?}

Essa pergunta esteve presente durante todo o processo de pesquisa, embora não tenha sido desencadeada durante a mesma. No ano de 2002, atuando em sala de aula como professora, essa inquietação já fazia parte de inúmeras outras questões que se manifestavam diante da diversidade dos meus alunos.

O que fazer para ensinar a todos, sendo que as diferenças dos tempos e ritmos de aprendizagem saltavam aos olhos? Como organizar o ensino para que os alunos com deficiência, com dificuldades de aprendizagem e todos os demais pudessem se apropriar do conhecimento? Como deveria planejar as ações pedagógicas, de forma a incluir a todos os alunos na dinâmica da aula? Os desafios que enfrentava como professora me conduziram à busca de respostas, mas nem sempre as encontrava.

Hoje entendo que este movimento de busca constituía-se espontaneamente, pois, pelas condições encontradas no cotidiano escolar, as reflexões ocorriam de forma isolada, sendo as mesmas produtos de reflexões pautadas nas minhas próprias experiências pedagógicas. Experiências essas que por vezes sinalizavam tentativas bem sucedidas, mas também por vezes indicavam equívocos por mim cometidos diante da diversidade dos alunos com quem trabalhava. Era um processo de busca por respostas com poucas oportunidades de estudo e de compartilhamento de ideias com outros professores devido às condições e às circunstâncias da realidade escolar. Ainda não compreendia os limites de uma ação pedagógica pautada nos princípios do professor reflexivo.

Baseada na experiência que tive junto aos alunos com e sem deficiência, em 2003, candidato-me a uma vaga e passo a integrar a equipe do CADE (Centro de Atenção ao Desenvolvimento Educacional), exercendo a função de PAEI ( professora assessora de educação inclusiva). Na itinerância, acompanhava o processo de desenvolvimento dos alunos com deficiência, bem como prestava assessoria aos seus professores. É neste período de 2003 a 2010 que meus questionamentos intensificam-se, pois passo a lidar diretamente com as expectativas, medos e estranhezas dos professores frente às manifestações advindas dos alunos que apresentavam necessidades educacionais especiais.

Creio que este breve relato sobre meu contato com os desafios advindos da educação que se intitula "inclusiva" não seja muito diferente do que ocorre com grande parte dos professores. Nessa condução, inicialmente, ao elaborar meu projeto de pesquisa, tinha 
como objetivo analisar o papel desempenhado pelo professor junto ao aluno com deficiência, no entanto, ainda atuando enquanto professora assessora de educação inclusiva, novas possibilidades são criadas em 2011 através da oportunidade de me integrar ao Grupo de Pesquisa Educação, Sociedade e Políticas Públicas: concepções da teoria histórico-cultural (GEPESPP), quando juntamente a outros integrantes passo a compreender o sentido e o significado de uma coletividade de estudos na formação profissional.

A partir do movimento de estudos, alarga-se minha compreensão acerca do processo educacional que estava inserida e, nesta dinâmica, os questionamentos diante das condições concretas da escola transformam-se e o objetivo enquanto pesquisadora passa a ser a busca pela compreensão a respeito dos limites e das possibilidades dadas a partir da gestão de política pública para o exercício da educação inclusiva para que, na continuidade da análise, pudesse apontar caminhos de superação a partir das necessidades desveladas durante a pesquisa.

Tal objetivo é apontado, pois, no exercício da função de professora assessora do CADE, sabe-se, que nas experiências do cotidiano da escola são comuns os relatos de queixas sobre os desafios que se apresentam ao professor que, em sala de aula, recebem alunos com deficiência ou se deparam com as manifestações dos alunos com dificuldades de aprendizagem. Dessa forma, este estudo problematiza a necessidade da implantação de uma escola que seja de fato para todos, pois muito tem sido discutido sobre a escola inclusiva como sendo aquela que matricula alunos com deficiência na sala regular de ensino, no entanto, busca-se ampliar essa abordagem analisando o papel do Estado e das Políticas Públicas de Educação, a função social da escola e suas finalidades.

Nessa proposição da pesquisa, apontam-se alguns elementos de aproximação e distanciamento entre os alunos com necessidades educacionais especiais, sendo eles alunos com deficiência ou com dificuldades de aprendizagem, pois decorre que tanto o professor quanto esses alunos se sentem excluídos no processo quando ambos não sabem lidar com as manifestações dos diferentes modos de aprender e de ensinar.

Sobre esse aspecto, Souza (2000, p. 126) colabora afirmando que "no meu educar repercutirão também minhas experiências pessoais: quando comunico meu mundo, contemporaneamente objetivo-me como alguém que já se apropriou desse mundo".

Nesta perspectiva, pode-se afirmar que processos de inclusão e exclusão se manifestam contraditoriamente no cotidiano escolar, a partir da produção da própria sociedade. Nosella $(2005$, p. 227) colabora declarando que "a escola não se explica por ela própria e sim pela relação política que mantém com a sociedade”, o que no sistema 
econômico e político vigente justifica o processo preconceituoso acerca da capacidade intelectual dos alunos oriundos de classes populares.

Nessa direção, sabe-se que no Brasil a exclusão enquanto produção social tem marcado os alunos que são frutos, em grande parte, das populações economicamente desfavorecidas. Portanto, declara-se uma aproximação entre os alunos com deficiência intelectual e os que apresentam dificuldades de aprendizagem, pois estes, na sua maioria, são pertencentes à classe trabalhadora. Tal afirmativa fundamenta-se em Carneiro (1997, p. 132) ao afirmar que “[...] no Brasil, a segregação que tem marcado os alunos considerados excepcionais se associa a toda uma história de exclusão de grande parte das populações marginalizadas".

Resgatando a história, segundo Carneiro (1997), sabe-se que, enfatizando as diferenças, o coeficiente intelectual classificava os sujeitos a partir de padrões de normalidade estabelecidos e, assim, os que não atendiam a este padrão eram classificados pelos desvios registrados abaixo da média, o que justificava sua inabilidade para fazer parte do sistema educacional regular. Novamente, tal perspectiva coloca-nos diante de uma aproximação entre os sujeitos com necessidades educacionais especiais; a busca pelo diagnóstico. Diagnóstico justificado pelas condições desfavoráveis de vida dos alunos com ou sem deficiência, o que declara a ineficiência no sujeito a partir das suas próprias produções e a partir da forma como se apresentam à escola.

Em se tratando dos sujeitos sem diagnóstico, sabe-se que estes eram encaminhados para avaliações seletivas e, agregando a isso, Carneiro (1997, p. 130) afirma que "há aqueles que, pelo diagnóstico e prognóstico anunciados por profissionais especializados, são considerados fracassados sem ao menos ter tido acesso à escolarização formal". Dessa forma, o fracasso escolar dos alunos com necessidades educacionais especiais se tornou justificável como sendo fruto das necessidades que foram mapeadas e localizadas no próprio indivíduo.

Deparamo-nos, novamente, com aproximação e distanciamento entre os alunos com e sem deficiência: o distanciamento pode ser declarado pelo fato de que o aluno com deficiência possui um diagnóstico (o que não justifica sua condição enquanto aprendiz), enquanto que a aproximação se dá pela incapacidade que é focalizada individualmente no sujeito, sem que seja considerado o seu contexto histórico. Outra aproximação é apontada quando os mesmos continuam constituindo a categoria dos excluídos da escola sem que sejam levados em conta os fenômenos que são viabilizados nas relações que estabelecem com o meio. 
Conhecedores da situação de miséria na qual se encontram muitos alunos da escola pública, o que se propõe nesta pesquisa é a busca por reflexões que se objetivem analisar a escola como aquela proclamada pelas leis, como sendo uma escola para todos no entanto, denuncia-se que no sistema econômico e político vigente a estrutura da escola pública não foi projetada para emancipar a todos os sujeitos que a ela se apresentam, incluindo, nessa estrutura, professores e alunos.

Portanto, ao problematizar a inclusão e a exclusão enquanto produção social, questiona-se até quando a escola se manterá excluindo os seus sujeitos pautando-se num discurso contraditório, pois na busca por compreender o caráter histórico-cultural, pode-se avançar nas discussões ao menos compreendendo que a deficiência e ou a dificuldade de aprendizagem são, antes de tudo, fenômenos que se apresentam à sociedade como produção social e cultural desta mesma sociedade e que, portanto, não são incapacidades irreversíveis e, muito menos, que podem ser justificadas como sendo próprias e exclusivas do próprio sujeito

Nesse alinhamento reflexivo, sabe-se que, para compreender na essência a realidade concreta da educação inclusiva, este estudo exige do pesquisador investimento de tempo e pesquisa em loco, pois, segundo Asbhar (2011), estando em contato com os sujeitos participantes e com as atividades relacionadas ao caso, o pesquisador se vê diante da necessidade de reflexão e interpretação sobre o que está em movimento.

Dessa forma, os aspectos dinâmicos da análise podem ser aqui relacionados, pois a unidade escolar, foco da pesquisa, foi alvo do meu trabalho enquanto professora assessora da educação inclusiva nos anos de 2009, 2010 e 2011.

Trata-se de uma EMEIEF - Escola Municipal de Educação Infantil e Ensino Fundamental, localizada no município do Santo André que, especificamente no ano de 2011, passa a ser assessorada concomitantemente ao processo de pesquisa. Sendo assim, entende-se que nesta escola reflexões foram desencadeadas inicialmente a partir de outro lócus, primeiramente como profissional da educação, o que culminou na sequência, enquanto pesquisadora, quando, estando semanal ou quinzenalmente na unidade escolar, pode-se acompanhar e coletar os dados durante um ano letivo junto à professora e sua equipe escolar.

A sala na qual a professora participante desta pesquisa estava integrada era composta por 26 alunos, sendo 16 meninos e 10 meninas. Desse total, uma aluna fazia parte da lista de acompanhamento da assessoria do CADE, pois tinha diagnóstico de Síndrome de Down. Se faz necessário clarificar que no decorrer do processo de acompanhamento, tendo como referência o objetivo da pesquisa atrelado à intenção de problematizar o conceito de educação inclusiva de forma abrangente, passa-se a acompanhar o desenvolvimento de um 
aluno dessa mesma classe que apresentava problemas de comportamento e de linguagem. Esse aluno passa a fazer parte da lista da assessoria; no entanto, sua professora e equipe se tornam alvos da pesquisa, uma vez que, de acordo com o objetivo, no desenrolar das ações pedagógicas, busca-se compreender os limites e as possibilidades dadas pela política pública para o desenvolvimento do processo educacional inclusivo.

Entendendo que somos sujeitos históricos e que nos encontramos integrados num contexto que nos influencia diretamente, problematizar as demandas que se apresentam à escola frente ao processo educacional inclusivo, permite clarificar a realidade propondo análises que podem explicar a realidade concreta a partir da sua essência, na objetivação de transformação da mesma.

Dessa forma, a investigação é planejada quando, para a análise dos dados, utilizam-se diversos registros realizados durante a assessoria no acompanhamento à escola. Embora outros instrumentos sejam utilizados na coleta dos dados, o instrumento de registro da assessoria é destacado, pois se entende que o mesmo, envolvendo a todos os sujeitos da escola, professora, professora assessora, agente social de inclusão e equipe escolar, indica o movimento dos mesmos frente a ação pedagógica.

Compondo com essa análise, de acordo com Vigotski (1998), entende-se que esta é uma pesquisa em movimento, pois se compreende que o foco investigativo é multifacetado e complexo, estando dessa forma relacionado a diversos determinantes históricos, culturais e sociais. Nessa perspectiva, de maneira abrangente, investiga-se múltiplos fenômenos no contexto de vida real, especialmente quando os limites entre os fenômenos e seu contexto não estão claramente definidos e precisam ser problematizados historicamente.

Em todas as intervenções propostas, este estudo conduz a análise de múltiplas manifestações da realidade concreta que se apresentam no contexto da educação inclusiva, direcionando as reflexões a partir do acompanhamento e análise da ação pedagógica do professor e do professor assessor junto aos demais sujeitos da escola.

Dessa forma, esta pesquisa é realizada através do acompanhamento sistemático à equipe escolar e à professora participante da mesma, quando, ampliando os instrumentos de dados, utilizam-se as pautas das reuniões da equipe do CADE e as agendas semanais e mensais da assessoria em consonância com os registros de avaliação da professora assessorada.

Sabe-se que estudar algo historicamente, significa analisar os fatos em movimento e, nesta perspectiva, ao analisar os limites e as possibilidades dadas pela política pública para 
o exercício da ação pedagógica do professor e do professor assessor no contexto da educação inclusiva, busca-se compreender a materialidade histórica destes sujeitos.

Portanto, buscando compreender as condições objetivas a partir da realidade concreta, buscam-se elementos teóricos que conduz analisar a totalidade da realidade pela lógica dialética, ou seja, pela historicidade determinada pelas múltiplas relações estabelecidas entre os sujeitos da escola com a gestão de política pública.

Nessa dinâmica, acredita-se ser possível capturar as intervenções no cotidiano da escola pela observação e pelo movimento do pensamento a partir da reflexão sobre a ação pedagógica do professor e do professor assessor na relação com os demais envolvidos no processo.

Dessa maneira, coloca-se que a base teórica desta investigação tem como princípio a construção do homem enquanto sujeito histórico cultural, quando seu desenvolvimento se dá por múltiplas determinações e pelas sucessivas mediações a partir do seu contexto social.

Nesse alinhamento, tomando como base teórica a psicologia-histórico- cultural e a pedagogia histórico-crítica, foram utilizados diversos procedimentos que permitiram apreender, analisar e compreender as condições dadas ao professor e ao professor assessor frente às suas ações pedagógicas junto ao coletivo da escola.

Indicando o caminho percorrido durante a pesquisa, coloca-se que tendo como referência o objetivo da mesma, iniciaram-se as investigações teóricas quando no capítulo Políticas de Estado conceitua-se educação e educação escolar, problematizando tais conceitos às políticas de Estado em educação, sendo enfatizadas as leis que asseguram o direito educacional do aluno com deficiência, destacando-se entre eles o AEE - Atendimento Educacional Especializado.

Como desdobramento, o capítulo III, intitulado Educação Inclusiva ou Educação para Todos, amplia-se o conceito de inclusão, apresentando o mesmo alinhado ao processo de exclusão, seu contexto e significado. Busca-se tal abordagem, entendendo que no cotidiano escolar da educação inclusiva, as relações estabelecidas se dão de maneira fragmentada, distanciando os sujeitos da possibilidade de compreensão dos fatos na sua essência.

Ainda nesse capítulo, busca-se apresentar a Declaração de Salamanca e problematiza-se a concepção de Necessidades Educacionais Especiais alinhada aos princípios educacionais inclusivos quando, na sequência, aborda-se o processo de municipalização de ensino de Santo André, enfatizando o percurso histórico da constituição do CADE - Centro de Atenção ao Desenvolvimento Educacional: Direitos Humanos. 
No capítulo IV, intitulado A Investigação na Realidade da Educação Inclusiva, apresenta-se a realidade concreta e os sujeitos no movimento da pesquisa e abordam-se as etapas da ação pedagógica reiterativa e reelaborada indicando que, no processo de transformação de uma etapa à outra, intencionalmente o instrumento de registro do professor assessor é reelaborado de forma a criar condições para que os dados fossem apreendidos em movimento.

Ainda nesse capítulo, apresentam-se as condições dadas pela gestão de política pública para o exercício da ação pedagógica do professor e do professor assessor a partir da relação destes com os sujeitos da escola e de todos estes com a gestão da política pública.

Sendo assim, entende-se que esta investigação é resultado de uma série de fatores histórico-culturais que evidenciam as influências do sistema econômico e político vigente que, de maneira intencional e articulada, conduzem a atuação dos sujeitos da educação. Essas influências foram analisadas e apresentadas no capítulo IV, a partir da categoria da governança do tempo e espaço, da imediaticidade das necessidades na realidade concreta e da dimensão tarefeira na ação pedagógica, pois entendendo que essas categorias estão diretamente relacionadas, a partir da condução teórica, as mesmas possibilitariam apreender e clarificar os limites e as possibilidades de atuação dos sujeitos imbricados no processo de educação inclusiva.

Como síntese do trabalho, no capítulo V, intitulado como Considerações Finais, aponta-se um conjunto de necessidades que precisam ser implementadas e articuladas pela gestão da política pública de Santo André na condução da superação do que está instituído no cotidiano da educação inclusiva.

Considera-se, assim, que esta pesquisa desvela alguns elementos presentes na cotidianidade da educação inclusiva e que estes contribuirão com as reflexões acerca da luta pela escola pública de qualidade, apontando que esta, para se tornar verdadeiramente inclusiva, precisa cumprir sua finalidade, sendo ela, a mediação da cultura e do conhecimento elaborado historicamente pelo homem, criando assim possibilidades para o desenvolvimento de todos os seus sujeitos. 


\section{POLITICAS PÚBLICAS DE EDUCAÇÃo}

Este capítulo problematiza a importância e as finalidades da Educação, e visa também a análise do papel das Políticas Públicas de Estado que dão sustentação à manutenção do formato de ensino posto em nossa sociedade, sendo necessário clarificar que no decorrer do texto, ao lidar com a categoria de Políticas Públicas, esta se refere especificamente as Políticas de Estado.

Sabe-se que as questões apresentadas, há muito vem sendo discutidas. No entanto, não se esgotam. Ao contrário, despertam em nós a necessidade de contribuição para a ampliação das discussões e reflexões que se direcionam em busca da qualidade do ensino público.

Dessa forma, objetiva-se conceituar Educação, Educação Escolar e apresentar conceitos relacionados às políticas de Estado em educação, quando organiza um conjunto de reflexões sobre a representação do Estado no sistema capitalista, e se apresentam as principais leis que asseguram o direito educacional do aluno com deficiência, destacando o AEE (Atendimento Educacional Especializado), serviço oferecido pela Educação Especial a ser praticado na escola regular de ensino.

Este capítulo recebe a contribuição da teoria histórico-cultural recorrendo a Bernardes (2012), que evidencia a importância de se levar em conta a constituição dos sujeitos como ser histórico, apontando que a escola precisa cumprir sua finalidade, sendo ela, a mediação do conhecimento elaborado historicamente pelo homem, criando assim possibilidades para o desenvolvimento dos sujeitos e para a transformação da sociedade.

O conceito de Educação é anunciado com a intenção de contribuir com as reflexões acerca de sua importância frente às possibilidades de transformação dos sujeitos e da sociedade, pois se entende que um ensino de qualidade poderá criar possibilidades de superação para a transformação do que está instituído.

Nesta objetivação, explicitam-se as políticas de Estado para a educação alinhandoas às reflexões em torno da conceituação de educação enquanto princípio humanizador em conformidade com a perspectiva teórica assumida. 


\subsection{Educação em geral}

Sabe-se que, a partir da educação, o conhecimento construído pelo homem pode ser mediado a favor de um processo de transformação social, fato explicitado quando Bernardes afirma que:

Entendemos que para que os fins da educação sejam atingidos a cultura em geral, o conhecimento científico e não científicos, os valores sociais, os costumes e processos instituídos nas diferentes sociedades, necessita ser mediado nos processos educativos e apropriado pelos sujeitos. (BERNARDES, 2010, p. 294)

Dessa forma, o referencial teórico que sustenta esse estudo indica a necessidade de problematização acerca da conceituação de educação, apontando a importância desta quando, dentro dos seus pressupostos, educação define-se como mediação no processo de emancipação humana. Nesse sentido, Bernardes declara que:

\footnotetext{
Entender educação como mediação no processo de emancipação humana pressupõe a compreensão de que o homem se constitui, dialeticamente, a partir das atividades que objetivam pelo processo de comunicação nas relações interpessoais, entre sujeitos com diferentes níveis da cultura, entendida como produção histórica elaborada pelo conjunto dos homens, e que tem como finalidade a promoção do humano no homem. (BERNARDES, 2010, p. 293)
}

Nessa perspectiva, compreende-se que educação se dá a partir da família e dos diferentes segmentos de grupos sociais cujos desenvolvimento e origem resultam do processo de autoconstrução humana. Nesse alinhamento reflexivo, Bertoldo (2010, p. 196) colabora declarando que "o homem não nasce com aptidões desenvolvidas, ao contrário, estas são geradas pelos próprios homens na medida em que vão criando o seu mundo exterior e a si mesmos".

Entendendo a educação a partir do referencial histórico cultural, sabe-se que há uma realidade já construída que a criança encontra quando vem ao mundo e, desta forma, entende-se a educação como fundamental no processo de humanização, pois, como já declarado, esta é mediadora no processo de emancipação dos sujeitos.

Segundo Bertoldo, (2010, p. 197) educação "trata-se de um processo que tem como uma de suas características a continuidade, pois sem esta a transmissão da cultura de uma geração para outra não seria possível". Desta forma, a função da educação é desenvolver as capacidades humanas, sendo essas ilimitadas.

$\mathrm{Na}$ abrangência do conceito de educação, coloca-se que as aptidões humanas se desenvolvem a partir da transmissão, produção e apropriação da cultura entre as gerações, e 
nesta perspectiva, define-se que cultura é tudo aquilo que dá significado às ações realizadas pelo homem na sociedade. Sobre este aspecto, Paro (2010, p. 89) afirma que "se a educação visa ao homem e a educação é a apropriação da cultura, é pela educação que nos fazemos humanos".

Sendo educação a apropriação da cultura, em consonância com o autor, cabe colocar que cultura envolve conhecimentos diante de tudo que o homem produz a partir de sua relação com a natureza quando este cria algo que não existe naturalmente. Sendo assim, o homem transforma o meio e a si mesmo, tornando-se sujeito histórico. Segundo Paro (2010, p. 25), “o homem faz história, portanto, ao produzir cultura” quando transcende a natureza. Portanto, coloca-se que a educação se destina à promoção do homem.

Cabe colocar que, por se tratar de um estudo cujo objetivo vincula-se à análise da práxis do professor frente ao processo educacional inclusivo, anuncia-se o conceito de práxis que, segundo Vasquez (1977, p.3), deve ser entendida "como atividade material do homem que transforma o mundo natural e social para fazer dele um mundo humano".

Desta forma, levando-se em consideração que educação tem um caráter de continuidade, e sendo ela destinada à promoção do homem constituído historicamente, na sequência problematiza-se o papel do Estado na educação buscando alinhar reflexões acerca das implicações desta no sistema capitalista.

\subsection{O papel do Estado na Educação}

A partir de algumas considerações a respeito do papel do Estado na Educação, coloca-se que esse representa um instrumento através do qual a sociedade, politicamente organizada, busca realizar seus objetivos no plano político. Segundo Saes, (1987), o Estado capitalista está organizado institucionalmente como se não existisse a divisão de classes. Dessa forma, entende-se que o Estado tem a função de reorganizar os interesses econômicos das classes dominadas para poder conciliar os interesses dessas com os interesses econômicos da classe dominante.

Sabe-se que é através do Estado que as sociedades buscam regularizar e coordenar sua ação social e econômica. Sobre este aspecto, Poulantzas (2000, p. 10) afirma que "é cada dia mais evidente que estamos enredados nas práticas de um Estado que, nos mínimos detalhes, manifesta sua relação com interesses particulares e, consequentemente bem 
precisos". Portanto, neste estudo, não se pode deixar de propor reflexões acerca do papel do Estado na educação. Ao entrar em contato com os fatos históricos, percebe-se que esse se mantém uma instituição que se distancia daquela que visa assegurar e garantir o acesso aos direitos de todos os seus cidadãos. Segundo Anibal Ponce, o Estado está articulado de forma a ser:

\begin{abstract}
Uma organização para governar os explorados, que se destacou da sociedade humana, e, aos poucos, diferenciou-se dela. Supõe a existência de um grupo especial de homens, os políticos, unicamente ocupados em governar, que se utilizam, para isso, de um organismo concebido para a subordinação da vontade de outrem, pela violência; este organismo compreende a política, o exército permanente, as prisões, os tribunais; é preciso acrescentar ainda os órgãos de pressão ideológica; o ensino, a imprensa, o rádio etc. Em resumo, o Estado não existiu sempre; o organismo do Estado não aparece senão no momento em que surge na sociedade a divisão em classes antagônicas, a exploração de classe. (PONCE, 1963, p. 290)
\end{abstract}

Respaldada pela obra de Saes (1987), coloca-se que o momento histórico atual evidencia a constituição de um Estado que se mantêm não só regulamentando a vida social, mas, sobretudo, segue regulamentando a vida do indivíduo, exercendo o seu poder como controlador em conformidade aos interesses de poucos que detêm o poder por intermédio do capital.

É possível entender essa atuação do Estado ao resgatar que, há algumas décadas , vivíamos sob o regime de uma ditadura que nos extraiu a condição de partícipes do processo político e hoje, diante da tentativa de construção de um movimento democrático, sinalizamos nossa pouca eficiência para este exercício. Saes (1987, p. 62) contribui nessa reflexão quando define democracia, declarando que "um regime político burguês só é efetivamente democrático quando o Estado assegura de fato as liberdades políticas (expressão, reunião, organização partidária) codificadas nos textos legais. Caso contrário, não passa de uma ditadura disfarçada $[\ldots]$ ”.

Assim sendo, problematiza-se o papel do Estado diante das obrigações para com todos os cidadãos e para com a garantia da igualdade dos direitos. No entanto, diante do contraste social, questiona-se esse movimento, pois se sabe que o mesmo segue garantindo o acesso aos bens comuns, não a todos, mas apenas a alguns. Nesse sentido, Saes afirma que:

Assim, para Marx e Engels, o Estado é o subgrupo de homens que desempenham a função de assegurar a continuidade da exploração do trabalho e de preservar a cisão da coletividade em classes sociais antagônicas [...] o Estado é uma organização em última instância, serviço da classe social exploradora. (SAES, 1987, p. 12-13) 
Diante das desigualdades, em conformidade com Silva (2011), pode-se questionar o cumprimento do papel do Estado no que se refere às demandas educacionais, ao compreender-se que a escola está inserida no processo capitalista e que, portanto, o Estado dirige a educação de acordo com as finalidades postas pela sociedade em que a classe dominante busca, através desse, realizar seus interesses. Segundo afirmação de Décio Saes:

[...] existe, portanto uma correlação entre a exploração do trabalho de uns homens por outros e um elenco de atividades, distintas do próprio processo de exploração, destinadas a assegurar a continuidade dessa relação de exploração. Se uma coletividade se acha dividida em classes sociais antagônicas (exploradora e explorada), deve ali existir um complexo de atividades, distintas das atividades de produção, destinadas a preservar esse estado de coisas; vale dizer, a assegurar a continuidade da divisão da coletividade em classe social exploradora e classe social explorada. A esse complexo de atividades Marx e Engels chamam Estado. (SAES, 1987, p. 11)

Diante da constatação de que o Estado, através de políticas públicas, busca assegurar a continuidade da relação de exploração, objetivando a manutenção do que está instituído, compreende-se que sua função, portanto, não é atender aos interesses de todos e, nessa proposição, inclui-se educação de qualidade.

No percurso da análise, entende-se que as questões que entravam o processo educacional transitavam pela sua estrutura, financiamento e concepções. Mas, sobretudo, os entraves se dão a partir das ideologias que estão a favor da classe dominante, como convêm retomar a partir de Poulantzas (2000, p. 53), ao declarar que "é no Estado capitalista que a relação orgânica entre trabalho intelectual e dominação política, entre saber e poder se efetua de maneira mais acabada".

Portanto, ao se pretender levar em conta a influência da educação a favor do processo de transformação do indivíduo e da sociedade, não se pode esquivar de problematizar o papel do Estado frente à organização e implantação de políticas públicas de educação, sendo necessário apoiar-se na análise feita por Fernandes (1979) que, analisando a década de 50, afirmava que o Brasil, acreditando dar início ao exercício da democracia, já deixava marcas que seria controlado pelas escolhas das minorias (classe dominante) e não pela coletividade (classe dominada).

No aprofundamento desse tema, reporta-se às reflexões propostas pelo autor ao apontar a importância do papel do Estado, colocando que este deveria empenhar-se em construir um sistema educacional compromissado com a tarefa de preparar o homem para a vida. Fernandes (1979) afirma que: 


\begin{abstract}
A função educativa da escola, no meio social brasileiro - e em particular a escola primária - não se restringe à instrução propriamente dita. Ela é muito mais ampla. Pois, por causa de condições e de fatores especiais, quando a escola não consegue transmitir certos conhecimentos, que em outras sociedades se propagam no seio da família ou de outros grupos sociais, esses conhecimentos ou não são difundidos ou precisam ser adquiridos através de penosos esforços individuais, nem sempre bem orientados. (FERNANDES, 1979, p. 110-111)
\end{abstract}

É possível identificar, através das considerações propostas por Fernandes (1979), sua crença no poder transformador da educação. Tal fato se evidencia a partir de seu envolvimento na Campanha em Defesa da Escola Pública, iniciada no final da década de 1950. Neste movimento, o autor propõe o ensino público laico, gratuito e de qualidade como direito e, portanto, essa garantia a um ensino público de qualidade só poderia se viabilizar através da atuação do Estado.

Sabe-se que os problemas educacionais existentes e as demandas da sociedade contemporânea tornam-se cada vez mais desafiadoras e complexas. Esta complexidade aponta que a educação, deve estar associada à ideia de sistema, sendo que na busca pelo enfrentamento desta problemática, faz-se necessária a análise e o esforço permanente em busca de caminhos que conduzam à superação do que está instituído na sociedade. Segundo Lessa e Tonet (2008, p.89), “o Estado capitalista afirma igualdade formal, política e jurídica com o objetivo real e velado de manter a dominação da burguesia sobre os trabalhadores", reforçando assim a desigualdade social.

Dessa forma, imersos nas circunstâncias produzidas pelo capitalismo, as desigualdades sociais, econômicas e culturais precisam ser analisadas e problematizadas. Entende-se, que a educação tem papel fundamental na condução desse processo histórico. Essa pode e deve recorrer à história construída pelo próprio homem na intenção de que este, num processo de análise e apropriação da própria cultura, possa se fortalecer e vislumbrar as possibilidades de participação política, objetivando minimizar tais desigualdades.

$\mathrm{Na}$ busca por contribuir com as reflexões acerca do processo educacional, na continuidade, conceitua-se educação pública e educação escolar, pois, como afirma Saviani (2006, p. 103) “já não é possível compreender a educação sem a escola, pois é nela que se dá a forma dominante de educação", entendendo que o homem não existe fora do mundo e da sua realidade.

\title{
2.3 Educação Pública e Educação Escolar
}


Ao anunciar a problemática acerca da educação pública, resgata-se o Manifesto dos Pioneiros de 1932, entendendo que as proposições apresentadas a partir do mesmo podem contribuir para a problematização do contexto atual de educação, pois, trata-se de um documento importante que buscou colocar a escola pública como instrumento de democratização da sociedade, sendo que o mesmo, referendou-se como um marco na educação brasileira ao eleger a escola pública, gratuita e laica como responsabilidade do Estado.

Trata-se aqui de anunciar um documento que, mesmo sendo datado de oito décadas atrás, sinaliza em seu teor, a tentativa de enfrentamento de muitos desafios que são atuais. Sob tal aspecto, Silva afirma:

Que as condições de vida se degradaram nos últimos anos já não é mais novidade. Esta degradação não é exclusiva nos educadores, mas está presente no conjunto de trabalhadores do setor público e privado. Entender as transformações por que passa a humanidade na atualidade é um desafio, mas, também é uma primeira condição no sentido de transformá-la. (SILVA, 2011, p. 146)

Nesse alinhamento reflexivo, reporta-se ao Manifesto dos Pioneiros uma vez que, tendo uma ampliada concepção de educação, seus representantes ${ }^{1}$, compreendiam que as instituições de cultura e educação deveriam ser movimentadas de forma a desenvolver um conjunto de medidas na projeção social da ação educativa para além dos muros da escola.

Sendo apontado como um marco na história da educação brasileira, o Manifesto dos Pioneiros consagrou a defesa formal da escola para todos, conferindo visibilidade às contradições no processo de escolarização, provocando, assim, o debate em torno da democratização do ensino. Segundo Saviani, (2004, p. 35), o Manifesto dos Pioneiros "pode, pois, ser considerado um importante legado que nos é deixado pelo século XX".

Desta forma, o Manifesto dos Pioneiros pode ser entendido como um divisor de águas na história da educação pública, conforme afirma Saviani:

O Manifesto apresenta-se, pois, como um instrumento político [...]. Expressa a posição do grupo de educadores que se aglutinou na década de 20 e que vislumbrou

\footnotetext{
${ }^{1}$ Signatários do Manifesto: Fernando de Azevedo, Afranio Peixoto, A. de Sampaio Dória, Anisio Spinola Teixeira, M. Bergstrom Lourenço Filho, Roquette Pinto, J. G. Frota Pessôa, Julio de Mesquita Filho, Raul Briquet, Mario Cassanta, C. Delgado de Carvalho, A. Ferreira de Almeida Jr., J. P. Fontenelle, Roldão Lopes de Barros, Noemy M. da Silveira, Hermes Lima, Attílio Vivacqua, Francisco Venâncio Filho, Paulo Maranhão, Cecília Meirelles, Edgar Sussekind de Mendonça, Armanda Alvaro Alberto, Garcia de Rezende, Nobrega da Cunha, Paschoal Lemme, Raul Gomes. (AZEVEDO, 2010, p.2)
} 
na Revolução de 1930 a oportunidade de vir a exercer o controle da educação no país. O ensejo para isso se manifestou por ocasião da IV Conferência Nacional de Educação realizado em dezembro de 1931, quando Getúlio Vargas, chefe do governo provisório, presente na abertura dos trabalhos ao lado de Francisco Campos, que se encontrava à testa do recém - criado Ministério da Educação e Saúde Pública, solicitou aos presentes que colaborassem na definição da política educacional do novo governo. (SAVIANI, 2004, p. 34)

Naquele momento histórico, Saviani, posicionava-se a favor da garantia ao acesso, gratuidade e laicização, entendendo a importância da fusão entre educação e progresso. Dessa forma, projetava-se a educação pública como elemento decisivo no percurso de desenvolvimento social do país, cabendo aqui colocar que essa concepção encontra-se presente atualmente nos discursos parlamentares, dificultando, assim, a compreensão da sociedade acerca da precariedade do ensino público.

Sob este aspecto, Silva colabora declarando que:

Snyders em Escola, classe e luta de Classe [...] assevera que na sociedade de classes, a função principal da escola é a inculcação da ideologia burguesa e a sujeição e o disfarce da ideologia proletária, para impedir o desenvolvimento da ideologia do proletariado revolucionária, pois ela qualifica o trabalho intelectual e desqualifica o manual, sujeitando o proletariado a ideologia burguesa [...] (SILVA, 2011, p 147)

Dessa maneira, segundo Silva (2011), compreende-se que ideologicamente o sistema de ensino público é resultado do papel histórico que a escola desempenhou no seu percurso, mascara a relação entre os resultados escolares e a origem social dos seus sujeitos.

Nessa direção, é válido reafirmar que a escola pública brasileira apresenta-nos desafios a serem superados. O quadro de exclusão social em que nos encontramos denuncia o modo como se organiza estrutural e politicamente uma sociedade capitalista. Portanto, é preciso estar alerta para coletivamente agirmos na busca por caminhos que conduzam à superação deste quadro, aqui em destaque, o campo educacional. A escola, na medida em que se adequou às exigências do capitalismo, respondendo pela sua reprodução e fortalecimento, foi conduzida a distanciar-se da sua função social. Essa reflexão é fundamentada em Saviani, quando afirma que:

[...] a escola é determinada socialmente; a sociedade em que vivemos, fundada no modo capitalista, é dividida em classes com interesses opostos; portanto a escola sofre a determinação do conflito de interesses que caracteriza a sociedade. (SAVIANI, 1982, p. 35)

Sendo assim, entende-se ser importante conceituar educação escolar. Nesse direcionamento, Silva (2011, p. 152) declara que "Snyders seguindo a tradição marxista 
enfatiza que a escola é palco da luta de classes e por isso deve ser utilizada pelas classes exploradas, pelas forças progressistas, como um dos seus instrumentos de luta e de libertação".

Ao anunciar a função da educação escolar, Paulo Freire (2011, p. 96) contribui para o desvelamento do conceito quando declara que "a educação é uma forma de intervenção no mundo". Sendo assim, sabe-se que à escola não cabe só formar indivíduos, pois se faz necessário compreender que tipo de sociedade e para que tipo de prática social o educador está formando seus alunos. Nesta perspectiva, reafirma-se a importância da educação escolar como mediação no processo de emancipação humana. Segundo Bernardes (2010, p. 294), compreende-se que "a escola tem o dever ético e político de ser o espaço social (oficial) onde o conhecimento, elaborado historicamente pelas ciências, deve ser ensinado e aprendido pelos sujeitos".

Saviani (2004) colabora nessa direção ao clarificar que a educação escolar distingue-se de outras formas espontâneas de educação devido à sua função: a produção da humanidade no homem alertando que, para tanto, a escola precisa ser capaz de transformar conceitos espontâneos em conceitos científicos.

Educação escolar, segundo Duarte (2007), corresponde à instituição cuja função social é ser propagadora do saber científico. Segundo o autor, a educação escolar é responsável pela reprodução da humanidade em cada indivíduo humano. Sendo assim, tornase inviável esse processo sem a mediação de uma atividade intencionalmente direcionada para esse fim. Duarte declara que:

[...] até um certo estágio do desenvolvimento histórico os homens podiam formar-se pelo simples convívio social. Após o surgimento da sociedade capitalista a reprodução da sociedade passa a exigir que a educação escolar, enquanto processo educativo direto e intencional, passe à condição de forma socialmente dominante de educação. (DUARTE, 2007, p. 50)

Sendo a educação escolar, entendida como a mediação da cultura em geral e do conhecimento historicamente elaborado pelo homem, questiona-se se essa tem conseguido atingir suas finalidades. Tal questão aponta ser necessário repensar a função social da educação escolar e sua importância. Sob esse aspecto, Nereide Saviani, declara que:

Quando se trata de definir qual saber a escola deve difundir, como e a quem, as ideias são as mais variadas, cruzam-se, aproximam-se, opõem-se, avançam, recuam, saem de cena, reaparecem, ostentam-se, dissimulam-se... a depender de correlação de forças, conforme as necessidades e exigências impostas pelas circunstâncias e pelos atores em movimento, em conflito.” (SAVIANI, 2010, p. 1) 
Sem esquivar-se das contradições que permeiam a escola pública, a partir da perspectiva teórica assumida, considera-se a educação escolar a maneira mais desenvolvida de formação. Entende-se que, desde sua origem, a educação está associada à necessidade de generalização do conhecimento científico sistematizado e, nessa dinâmica, sabe-se que o conhecimento deve ser apropriado pela objetivação de uma prática educativa que leve em consideração os sujeitos, sua presença no mundo, suas crenças e valores, bem como suas expectativas e necessidades de acesso ao conhecimento.

Segundo Duarte (2007, p. 9), "ressalta-se a importância do caráter mediador entre o cotidiano e o não-cotidiano realizado pela educação escolar", o que conduz pensar na importância da escola. Quando os profissionais da educação compreendem a relação entre a função educativa e a prática social, podem contribuir para a transformação da consciência dos homens para que estes possam transformar a sociedade.

Nessa perspectiva, problematizar educação escolar é reconhecer sua importância para o processo de emancipação dos sujeitos. Duarte (2007) prossegue indicando:

[...] afirmamos a necessidade de a prática pedagógica escolar produzir no indivíduo necessidades não cotidianas, como por exemplo, a necessidade de teorização científica, da reflexão filosófica, da configuração artística da realidade, da análise política, não estamos afirmando que tais necessidades surgirão do nada ou se apresentarão como inteiramente estranhas ao pensamento cotidiano. Estamos sim afirmando que deve haver um processo dialético de superação por incorporação. A fantasia do cotidiano não se transforma em arte espontaneamente, mas sim pelo contato com a arte produzida socialmente. (DUARTE, 2007, p. 60)

Retoma-se que, entendendo o homem como sendo sujeito histórico, é necessário direcionar a atenção para o fato de que esse se humaniza na medida em que suas potencialidades são desenvolvidas, e esse processo se intensifica a partir da apropriação do conhecimento, daí a importância da escola.

Importância e necessidade, pois enquanto cultura, segundo Paro (2010, p. 26), “o conteúdo da escola é a própria cultura humana”, o que a faz ser capaz de capacitar o homem a tornar-se história pela sua condição de sujeito. Na medida em que entra em contato com as Artes, as Ciências e a Política, o homem se faz e faz a história produzindo e se apropriando da cultura. E essa pode estar a favor da transformação do próprio homem e da sociedade, portanto é importante que a educação seja organizada com vistas à formação dos sujeitos plenamente valorizada do ponto de vista social. Cabe colocar que se entende, que a escola torna-se relevante quando consegue organizar o trabalho educativo como sendo atividade 
orgânica da vida cotidiana, assim como quando realiza a ação pedagógica como atividade não cotidiana, pois, segundo Duarte (2007, p. 50), “o conjunto da atividade social não pode se reproduzir se não é reproduzida nos indivíduos a humanidade produzida historicamente".

Nessa direção, entende-se que se acentua a importância da escola frente à análise dos fatos históricos e, consequentemente, das desigualdades sociais. Sabe-se, portanto, que na medida em que a escola apresentar aos alunos a história do homem e a importância deste enquanto sujeito partícipe do processo de humanização, essa poderá potencializar suas possibilidades de superação e transformação do que está posto na sociedade.

Portanto, faz-se necessária a compreensão do que está instituído entre as políticas públicas, educação e sociedade, pois, como indica Freire (1983, p.16), “a primeira condição para que um ser possa assumir um ato comprometido está em ser capaz de agir e refletir". Esse movimento só se faz possível por intermédio da apropriação do conhecimento que ultrapassa os limites da espontaneidade.

Assim sendo, pode-se pensar as finalidades da educação, refletindo sobre sua importância para, mais a frente, alinhá-la à importância da práxis do professor frente à educação escolar, pois o autor propõe inquietações quando defende que:

O caráter inacabado dos homens e o caráter evolutivo da realidade exigem que a
educação seja uma atividade contínua. A educação é, deste modo, continuamente
refeita pela práxis. Para ser, deve chegar a ser. [...] A educação problematizadora -
que não aceita nem um presente bem conduzido, nem um futuro predeterminado -
enraíza-se no presente dinâmico e chega a ser revolucionária. [...] Ela afirma que os
homens são seres que se superam, que vão a frente e olham para o futuro, seres para
os quais a imobilidade representa uma ameaça fatal, para os quais ver o passado não
deve ser mais que um meio para compreender claramente quem são e o que são, a
fim de construir o futuro com mais sabedoria. Ela se identifica, portanto, com o
movimento que compromete os homens como seres conscientes de sua limitação,
movimento que é histórico e que tem o seu ponto de partida, o seu sujeito, o seu
objetivo. (FREIRE, 2001, p. 94-95)

Pela perspectiva teórica assumida, entende-se que, apesar da importância que a escola exerce no meio em que está inserida, ainda assim, tem limites de ação principalmente em uma sociedade fundada na divisão de classes sociais. $\mathrm{O}$ percurso histórico tem mostrado que, no sistema capitalista, a educação não tem cumprido sua função social, estando subordinada ao movimento histórico determinado pelas relações políticas e econômicas.

Em consonância com as reflexões colocadas, entende-se que os investimentos insuficientes, associados à descontinuidade das políticas públicas educacionais, conferiram à educação uma condição de desqualificação frente à promoção da cultura e à apropriação do conhecimento. Sabe-se que muitas são as mazelas no campo educacional, como os baixos 
salários, situações precárias dos equipamentos públicos, salas superlotadas e a superficialidade acadêmica na qual são formados os professores, e esse cenário vem se fortalecendo, pois, como declara Patto:

Todos sabemos que anos e anos de uma política educacional que tem na base o descaso pela boa qualidade da escola para o povo, num país extremamente desigual do ponto de vista socioeconômico e secularmente marcado pelo cinismo diante dos direitos dos cidadãos, acabaram por instalar nas escolas uma dinâmica institucional, muitas vezes difícil e até mesmo cruel, que traz danos diários a todos os envolvidos no processo: técnicos, administradores, professores, funcionários, alunos e famílias usuárias da escola[...]Há apropriação privada do espaço público das escolas pelos educadores ( muitas vezes como estratégia de sobrevivência em condições de trabalho adversas). Há solidão, desamparo, raiva, ressentimento, corpo mole e corpo duro - ou seja, formas de resistência passiva e ativa. Há corporativismo, defesa de privilégios e disputas pelo poder. Há sentimentos de impotência e fatalismo, há pouca esperança [...] (PATTO, 2005, p. 19-20)

Recorrendo a Patto (2005), entende-se que a crise da educação, junto aos que estão diretamente envolvidos, passa pelas condições acima. Dessa forma, entendendo que uma visão crítica da realidade é necessária para que se busque compreender com clareza o que está presente neste momento histórico, coloca-se a intenção de continuidade da problematização sob a importância da educação. Muitas são as leis que chamam a atenção da sociedade para as ações implementadas pelo Estado junto à mesma, então, entende-se que cabe neste texto, destacar algumas destas leis que nortearão as reflexões no encadeamento das discussões sobre os direitos no campo educacional.

\subsection{Constituição de 1988 e LDB: Desdobramentos Educacionais}

Os direitos humanos anunciados na Constituição Federal (BRASIL, 1988) sinalizaram a intenção da construção de uma sociedade justa, livre e igualitária. A Constituição Federal registrou a necessidade de erradicação da pobreza, analfabetismo e a tentativa da redução das desigualdades sociais e do preconceito; no entanto, o panorama atual não é condizente com esta intenção, valendo destacar aqui preocupações referentes ao quadro educacional.

Há 24 anos, a promulgação da Constituição Federal manifestava a importância de um plano nacional de educação que favorecesse a tríade aluno, professor e conhecimento. Segundo o artigo 241: 
A lei estabelecerá o plano nacional de educação, de duração plurianual, visando articulação e ao desenvolvimento de ensino em seus diversos níveis e à integração das pessoas do poder público que conduzem à:

I- erradicação do analfabetismo

II- universalização do atendimento escolar

III- melhoria da qualidade de ensino

IV- formação para o trabalho

V- promoção humanística, científica e tecnológica do país ${ }^{2}$ (BRASIL, 2010, p. 35)

$\mathrm{Na}$ constituição brasileira fica evidenciada a preocupação tanto com a qualidade no processo de universalização de ensino, quanto no processo de formação mais humanista, o que, diretamente neste estudo, implica pensarmos o processo educativo frente ao acesso, qualidade e permanência dos alunos nas escolas públicas.

$\mathrm{Na}$ tentativa de qualificar essa problematização, é necessário resgatar alguns artigos da Lei de Diretrizes e Bases que estão alinhados à Constituição Federal (BRASIL, 1988) para que, na sequência da análise, possamos deter nossa atenção especificamente no Capítulo $\mathrm{V}$ da $\mathrm{LDB}$, quando problematizarmos as questões referentes a sua regulamentação numa perspectiva de educação de qualidade para todos.

A LDB entrou em vigor em Dezembro de 1996, tornando-se a principal lei da educação no país. De forma abrangente, reporta-se ao processo educativo englobando não só a educação ofertada pela escola, mas também àquela desencadeada junto à família, o trabalho e espaços de convivência em geral. Segundo Saviani:

A Lei n 9.394, de 20 de Dezembro de 1996 que ' estabelece as diretrizes e bases da educação nacional', em vigor a partir de sua publicação no Diário oficial da União de 23 de dezembro de 1996, embora não tenha incorporado dispositivos que claramente apontassem na direção da necessária transformação da deficiente estrutura educacional brasileira, ela, de si, não impede que isso venha a ocorrer. (SAVIANI, 2006, p.238)

A Lei de Diretrizes e Bases da Educação Nacional, no seu artigo $3^{\circ}$, em conformidade com a Constituição Federal no artigo 206, dispõe sobre os princípios gerias que regem a educação brasileira. A LDB não só veio acrescentar informações ao que já estava posto pela Constituição, mas também trouxe para o foco das políticas públicas, a necessidade do reordenamento de suas ações.

Sendo uma lei que especificamente se volta à Educação, já no $1^{\circ}$ artigo, enfatiza a importância desta em diferentes segmentos como a escola, a família e os espaços de convivência, como já colocado anteriormente.

\footnotetext{
${ }^{2}$ Constituição da República Federativa do Brasil de 1988
} 
No $2^{\circ}$ artigo a Lei de Diretrizes e Bases, em consonância com o artigo 205 da Constituição Federal, coloca a importância e necessidade de um processo educacional que instrumentalizasse o aluno, favorecendo o seu pleno desenvolvimento para o exercício da cidadania e sua qualificação para o mercado de trabalho. Saviani prossegue mostrando que, quanto aos princípios e fins da educação, o texto da LDB limita-se:

Praticamente, a repetir os artigos 205 e 206 da Constituição Federal, com alguma adaptação redacional e acrescentando, em consonância com o conceito de educação do artigo primeiro e seu parágrafo segundo, os princípios da 'valorização da experiência extra - escolar' e ' vinculação entre educação escolar, trabalho e as práticas sociais’. (SAVIANI, 2006, p. 202).

No artigo $5^{\circ}$ da LDB, é regulamentado o direito à educação prevista também no parágrafo $1^{\circ}$ do artigo 208 da Constituição Federal, e especificando que esse exercício poderá ser executado pelo cidadão, associação comunitária, organização sindical, entidade de classe ou outra constituída legalmente assim como o Ministério Público. No parágrafo $4^{\circ}$ desse mesmo artigo, coloca-se a responsabilidade, garantia e oferta do ensino obrigatório, atribuindo competência deste aos Estados e Municípios.

Do artigo $8^{\circ}$ ao $20^{\circ}$, a LDB apresenta de modo geral as diretrizes que tratam da estrutura da organização educacional, assim como coloca as normas e regimentos quanto ao seu funcionamento. $\mathrm{O}$ artigo $8^{\circ}$ propõe que os Estados, União e Municípios (em regime de colaboração) organizem os sistemas de ensino, enfatizando no parágrafo $2^{\circ}$ deste mesmo artigo que "os sistemas de ensino terão liberdade de organização nos termos desta lei" (SAVIANI, 2006, p. 166).

Dos artigos $12^{\circ}$ ao $14^{\circ}$, a LDB trata diretamente da responsabilidade da escola e dos professores frente ao processo de ensino e aprendizagem:

Art. 12. Os estabelecimentos de ensino, respeitadas as normas comuns e as do seu sistema de ensino, terão a incumbência de:

I - elaborar e executar sua proposta pedagógica;

II - administrar seu pessoal e seus recursos materiais e financeiros;

III - assegurar o cumprimento dos dias letivos e horas-aula estabelecidas;

IV - velar pelo cumprimento do plano de trabalho de cada docente;

$\mathrm{V}$ - prover meios para a recuperação dos alunos de menor rendimento;

VI - articular-se com as famílias e a comunidade, criando processos de integração da sociedade com a escola;

VII - informar os pais e responsáveis sobre a freqüência e rendimento dos alunos, bem como sobre a execução de sua proposta pedagógica. (BRASIL, 2010, p. 16 17)

O debate educacional aqui proposto gira em torno do compromisso político dos profissionais da educação, sendo necessário refletir sobre a universalização do acesso a uma 
escola de qualidade que cotidianamente precisa ser problematizada pelos seus sujeitos. Evidencia-se a necessidade do empenho das equipes em articular e problematizar as práticas curriculares, suas formas de avaliação, assim como se faz necessário analisar e potencializar as reflexões acerca do processo de formação dos profissionais que tem essa responsabilidade social frente a demanda de articulação junto a comunidade escolar.

A redação da LDB no seu artigo $13^{\circ}$ deixa registrada a importância da articulação desse processo a partir do exercício da função dos professores e da equipe gestora, quando coloca que:

Art. 13. Os docentes incumbir-se-ão de:

I - participar da elaboração da proposta pedagógica do estabelecimento de ensino;

II - elaborar e cumprir plano de trabalho, segundo a proposta pedagógica do estabelecimento de ensino;

III - zelar pela aprendizagem dos alunos;

IV - estabelecer estratégias de recuperação para os alunos de menor rendimento;

V - ministrar os dias letivos e horas-aula estabelecidos, além de participar integralmente dos períodos dedicados ao planejamento, à avaliação e ao desenvolvimento profissional;

VI - colaborar com as atividades de articulação da escola com as famílias e a comunidade. (BRASIL, 2010, p. 16 - 17)

Ressaltamos que no artigo $14^{\circ}$, a LDB coloca que a escola tem autonomia frente ao processo de elaboração do Projeto Político Pedagógico, merecendo destaque por se tratar de uma conquista na qual a redação do texto coloca que:

Art. 14. Os sistemas de ensino definirão as normas da gestão democrática do ensino público na educação básica, de acordo com as suas peculiaridades e conforme os seguintes princípios:

I - participação dos profissionais da educação na elaboração do projeto pedagógico da escola;

II - participação das comunidades escolar e local em conselhos escolares ou equivalentes. (BRASIL, 2010, p. 17)

A partir do encadeamento de reflexões para a construção coletiva do Projeto Político Pedagógico, as escolas podem desencadear ações partindo do mapeamento das reais necessidades dos sujeitos envolvidos (pais, professores e alunos), instrumentalizando-os assim para a tomada de decisões frente à tentativa de superação e transformação do que está instituído, pois alertados por Freire, somos conduzidos a considerar que:

Para ser válida, a educação, deve considerar a vocação ontológica do homem vocação de ser sujeito- e as condições em que ele vive [...] mais exatamente, para ser instrumento válido, a educação deve ajudar o homem, a partir de tudo o que constitui sua vida, a chegar a ser sujeito. (FREIRE, 2001, p. 39) 
Tal processo representa um avanço significativo, pois na medida em que descentraliza esta ação de cunho pedagógico, a LDB viabiliza a possibilidade de tomada de decisões das equipes escolares. Estas, na busca pela construção coletiva de um Projeto Político Pedagógico que pode levar em consideração as necessidades dos alunos, podem, a partir dos conteúdos, problematizar e potencializar o desenvolvimento dos sujeitos através da mediação do conhecimento.

No artigo $12^{\circ}$ da LDB, no estabelecimento das ações a serem desenvolvidas pela escola, a LDB apresenta em sua redação a responsabilidade desta em "informar os pais e responsáveis sobre a freqüência e o rendimento dos alunos, bem como sobre a execução de sua proposta pedagógica”. (BRASIL, 2010, p. 16)

Tanto os artigos $12^{\circ}$ e $13^{\circ}$ da LDB, quanto o artigo $14^{\circ}$ da mesma lei, propõem pensar o envolvimento da comunidade escolar ao expressarem a importância e necessidade de a escola, seus professores e equipe, desenvolverem esforços no sentido de propor ações educativas que objetivem a integração da escola com as famílias e, destas, com a comunidade em geral. $\mathrm{O}$ artigo $15^{\circ}$ da LDB complementa o que foi estabelecido no seu artigo 14 quando dispõe que:

Art. 15 - Os sistemas de ensino assegurarão às unidades escolares públicas de educação básica que os integram progressivos graus de autonomia pedagógica e administrativa e de gestão financeira, observadas as normas gerais do direito financeiro público. (BRASIL, 2010, p. 17)

$\mathrm{Na}$ sequência, os artigos $16^{\circ}, 17^{\circ}$ e $18^{\circ}$ da LBD (BRASIL, 2010) tratam da composição dos sistemas de ensino nos âmbitos federal, estadual e municipal, quando destacamos que o artigo $16^{\circ}$ refere-se ao sistema federal de ensino, compreendendo as instituições mantidas pela união, instituições de ensino superior criadas e mantidas pela iniciativa privada e pelos órgãos federais de educação, enquanto que no artigo $17^{\circ}$, os sistemas de ensino dos Estados e Distrito Federal compreendem as instituições mantidas pelo Poder Público Estadual e Distrito Federal. No artigo $18^{\circ}$, a lei coloca que os sistemas municipais compreendem as instituições de ensino fundamental, médio e de educação infantil mantidas pelo Poder Municipal.

Nos artigos $19^{\circ}$ e $20^{\circ}$, a LDB classifica as categorias administrativas nas instituições públicas e privadas, colocando que as instituições de ensino público serão criadas e administradas pelo Poder Público enquanto que as instituições privadas serão mantidas e administradas por pessoas físicas ou jurídicas. $\mathrm{O}$ artigo $20^{\circ}$ coloca ainda que as instituições 
privadas de ensino serão categorizadas como sendo particulares em sentido restrito, comunitárias, confessionais e filantrópicas.

De maneira resumida, descreve-se até aqui os artigos que, de forma geral, colocam as diretrizes para a educação, sendo válido acrescentar que Saviani, ao problematizar a LDB, propõe pensar que:

[...] a lei, ainda que pareça paradoxal, é mais indicativa do que prescritiva. Trata-se, como se observou, de uma 'lei minimalista', que deixa muita coisa em aberto, aparentemente para viabilizar as ações do MEC cujo papel é reforçado em face das atribuições que a lei confere à União nos termos do parágrafo primeiro do artigo oitavo e dos nove incisos e três parágrafos do artigo nono, concentrando aí as tarefas de coordenação da política educacional e a articulação dos diferentes níveis e sistemas de ensino com funções normativas, redistributivas e supletivas; a definição de competências e diretrizes para nortear os currículos da educação infantil, do ensino fundamental e do ensino médio; e a avaliação do rendimento das escolas de todos os níveis de ensino. (SAVIANI, 2006, p. 226)

Não restam dúvidas que a LDB é uma lei mais indicativa do que prescritiva, como declarou Saviani, pois a mesma, nas entrelinhas da sua redação, evidencia a intenção de viabilizar ações que possam estar a serviço da manutenção do que está instituído. Segundo Saviani (2006), o embate se pôs no processo de tramitação da Lei e está reposto no encaminhamento de sua implantação. $\mathrm{O}$ autor prossegue sua análise mostrando que:

Os que se identificam com a forma social atualmente existente procurarão responder
às questões postas pela implantação da nova legislação educacional na direção da
consolidação do status quo, evitando mudanças ou incorporando aquelas inovações
que concorrem para esse objetivo. De outro lado, os que visam à transformação da
ordem existente, se empenharão no encaminhamento das questões educacionais em
sintonia com as necessidades de transformação. (SAVIANI, 2006, p. 238)

Sabe-se que toda legislação é fruto de interesses e que há acordos e alianças políticas envolvidas no seu processo de construção.

É válido colocar que uma lei não é uma diretriz infalível e abstrata, a partir da qual todo o contexto real vai ser ordenado. Neste alinhamento reflexivo, não podemos também desconsiderar que essa lei reflete intencionalidades da sociedade que a produziu, e que esta orienta a prática social no sentido de possibilitar seu controle e sua regulação. Com a LDB não é diferente, conforme aponta Saviani:

Segue-se, pois, que, de modo especial em face de uma lei que deixou muita coisa em aberto, os seus limites, expressos dominantemente na forma de omissões, podem se converter na abertura de novas perspectivas para a educação brasileira. A realização dessa possibilidade, contudo, está na dependência da capacidade de mobilização e de ação das forças identificadas com a necessária transformação da nossa organização 
escolar tendo em vista a construção de um sistema nacional de educação que garanta a todos o acesso e conclusão da educação básica. (SAVIANI, 2006, p. 227)

Por se tratar de um estudo cujo objetivo vincula-se à análise da práxis do professor frente ao processo educacional inclusivo, após a análise da LDB no que se refere à educação em geral, torna-se necessário focar o estudo das relações educativas no contexto específico da pesquisa. Assim, serão abordadas as diretrizes colocadas pela LDB frente à Educação Especial.

$\mathrm{Na}$ análise da LDB, no capítulo $\mathrm{V}$ (que trata especificamente da Educação Especial), no artigo 58, a lei possibilita diferentes interpretações dos sistemas de ensino, conduzindo a adoção de um atendimento direcionado às pessoas com deficiência de acordo com concepções diversas. Esta redação dá margens a diferentes interpretações ao declarar que “entende-se por educação especial, para os efeitos desta Lei, a modalidade de educação escolar, oferecida preferencialmente na rede regular de ensino, para educandos com necessidades especiais". (BRASIL, 2010, p. 43). Tais interpretações possibilitam a substituição da matrícula do aluno na rede regular pela matrícula na Educação Especial, confrontando com o que está colocado na Constituição Federal (art. 208, inc. I), que determina que o acesso ao ensino regular é obrigatório a todos indistintamente.

Destaca-se o Capítulo V que traz, em sua redação, orientações para o atendimento às pessoas com deficiência, sendo somente indicativa quando não prescreve o formato do serviço e suas especificações como pode ser analisado a seguir na redação dos artigos 58 ao 60 da LDB:

\footnotetext{
Art.58

$\S 1^{\circ}$ Haverá, quando necessário, serviços de apoio especializado, na escola regular, para atender às peculiaridades da clientela de educação especial.

$\S 2^{\circ} \mathrm{O}$ atendimento educacional será feito em classes, escolas ou serviços especializados, sempre que, em função das condições específicas dos alunos, não for possível a sua integração nas classes comuns de ensino regular.

$\S 3^{\circ} \mathrm{A}$ oferta de educação especial, dever constitucional do Estado, tem início na faixa etária de zero a seis anos, durante a educação infantil. (BRASIL, 2010, p. 43 44)
}

Uma vez que se aborda as diretrizes da LDB, cabe aqui colocar, em acordo com Saviani (2006), que as brechas desta lei conduziram os sistemas à adoção de diferentes formatos de atendimento. Especificamente aqui, as brechas permitiram interpretações diferenciadas frente às demandas dos alunos com deficiência. 
As bases colocadas pela lei, não explicitam a responsabilidade do Estado quando foca na ação de cada professor, de cada escola, de cada sistema educacional, sua responsabilidade na execução da mesma, clarificado no artigo $59^{\circ}$ da lei que coloca:

Art. 59. Os sistemas de ensino assegurarão aos educandos com necessidades especiais:

I - currículos, métodos, técnicas, recursos educativos e organização específica, para atender às suas necessidades;

II - terminalidade específica para aqueles que não puderem atingir o nível exigido para a conclusão do ensino fundamental, em virtude de suas deficiências, e aceleração para concluir em menor tempo o programa escolar para os superdotados; III - professores com especialização adequada em nível médio ou superior, para atendimento especializado, bem como professores do ensino regular capacitados para a integração desses educandos nas classes comuns;

IV - educação especial para o trabalho, visando a sua efetiva integração na vida em sociedade, inclusive condições adequadas para os que não revelarem capacidade de inserção no trabalho competitivo, mediante articulação com os órgãos oficiais afins, bem como para aqueles que apresentam uma habilidade superior nas áreas artística, intelectual ou psicomotora;

$\mathrm{V}$ - acesso igualitário aos benefícios dos programas sociais suplementares disponíveis para o respectivo nível do ensino regular. (BRASIL, 2010, p. 44 - 45.)

Nesse momento da redação, a lei indiretamente faz referência ao Atendimento Educacional Especializado (tema que trataremos na seqüência do capítulo), colocando no seu artigo $60^{\circ}$ que:

Art. 60. Os órgãos normativos dos sistemas de ensino estabelecerão critérios de caracterização das instituições privadas sem fins lucrativos, especializadas e com atuação exclusiva em educação especial, para fins de apoio técnico e financeiro pelo Poder Público.

Parágrafo único. O Poder Público adotará como alternativa preferencial, a ampliação do atendimento aos educandos com necessidades especiais na própria rede pública regular de ensino, independentemente do apoio às instituições previstas neste artigo. ( BRASIL, 2010, p.45)

Sabe-se que o acesso à Educação é um direito humano, sendo que na Constituição, a partir do art. 205 (BRASIL, 1988), educação refere-se àquela que visa o pleno desenvolvimento humano e o seu preparo para o exercício da cidadania. Nessa perspectiva, reforça-se a necessidade de investimentos na formação dos professores que estarão mediando o conhecimento de todos os alunos que se apresentam à escola.

É válido retomar que os governos locais puderam optar pelo formato do atendimento oferecido às pessoas com deficiência de acordo com seus interesses e concepções. Esse serviço, durante os anos que se seguiram à promulgação da LDB, pode então ser oferecido a partir de escolas especiais, integrativas ou inclusivas. O serviço 
oferecido às pessoas com deficiência pode também ser viabilizado e mantido pelos sistemas de ensino em instituições especializadas.

Todos os modelos de atendimento citados, apoiando-se legalmente na interpretação dos artigos $58^{\circ}$ aos $60^{\circ}$ do capítulo V da Lei de Diretrizes e Bases 9394/96, onde se coloca a Educação Especial como sendo aquela que seria ofertada preferencialmente na rede municipal de ensino.

Em se tratando da LDB, tem-se a clareza de que há muito a ser analisado e problematizado, mas com a intenção de continuar a problematização sobre a função da escola e esta como sendo uma instituição que tem uma função social instituída historicamente, e que deve garantir a todos, indistintamente, resgataremos na próxima seção, a Declaração de Salamanca por entendermos ser este também um documento norteador para a construção de uma escola inclusiva.

Com o objetivo de apresentar as principais leis que se referem à educação, vincula-se à importância da instituição escolar como sendo um espaço educativo que deve ser garantido para todos. Portanto, o que se apresentou até agora evidencia a importância do processo educativo da escola regular, pois os alunos, independente de suas características, necessitam apropriar-se do conhecimento.

Dessa maneira, é necessário direcionar reflexões para o contexto escolar analisando as relações dinâmicas que ali se estabelecem procurando compreender os seus desdobramentos historicamente.

Pensar na escola para todos os alunos, independente de suas características, é necessário e desafiador, pois se encontra nas entrelinhas das leis, lacunas que ao longo de décadas, vão possibilitando a reprodução do que está instituído socialmente.

Sabe-se que a escola precisa cumprir sua função social, e recorre-se a Saviani que propõe analisar que:

Decorre daí a exigência de se desbastar o cipoal das diferentes visões de educação que por vezes se enredam, dificultando a fixação do que é essencial. Por conseguinte, o que em si mesmo é relativamente simples acaba exigindo uma certa atenção, um certo cuidado, um estudo mais detido do conjunto das questões educacionais, a fim de que possamos fixar com clareza os alvos a atingir e tomar as providências cabíveis para torná-los realidade. (SAVIANI, 2006, p. 158)

Quando se chama a atenção para as brechas existentes na LDB, principalmente nos artigos que se referem ao processo educacional para as pessoas com deficiência, entendese que as diretrizes para a implantação deste serviço não sinalizam mudanças substanciais na 
sua implantação, ao contrário, evidenciam-se os interesses políticos advindos do processo no qual o ensino e a aprendizagem ainda não são colocados como eixos centrais.

Ao se reportar à escola e ao direito à educação, tem-se como objetivo contribuir com um debate que se faz necessário: não é qualquer tipo de acesso à educação que atende o princípio posto na Constituição Federal (1988). E é desse direito, norteado pelos princípios de qualidade e equiparação de oportunidades que estamos tratando quando o colocamos para as pessoas com deficiência e ou dificuldades de aprendizagem; direito do quais todos são titulares.

Não se pode, portanto, aceitar que esse direito seja traduzido somente com o cumprimento da obrigação de matrícula e manutenção dos discentes na escola, pois, segundo Glat e Nogueira:

[...] vale sempre enfatizar que a inclusão de indivíduos com necessidades educacionais especiais na rede regular de ensino não consiste apenas na sua permanência junto aos demais alunos, nem na negação dos serviços especializados àqueles que deles necessitem. Ao contrário, implica numa reorganização do sistema educacional, o que acarreta a revisão de antigas concepções e paradigmas educacionais na busca de se possibilitar o desenvolvimento cognitivo, cultural e social desses alunos, respeitando suas diferenças e atendendo às suas necessidades. (GLAT e NOGUEIRA, 2002, p.26)

Assim, entende-se que a implantação e o planejamento voltado às políticas educacionais que visam atender qualitativamente os alunos com necessidades educacionais especiais requerem domínio conceitual sobre o processo. O princípio ético-político, a definição de diretrizes e os programas precisam atentar para as mudanças necessárias no âmbito do atendimento aos alunos com estas especificidades, pois a divergência de concepções e práticas sinalizam a urgente necessidade de superação com o que está instituído. Nesta direção, Mendes considera que:

No contexto da educação, o termo inclusão admite, atualmente, significados diversos. Para quem não deseja mudança, ele equivale ao que já existe. Para aqueles que desejam mais, ele significa uma reorganização fundamental do sistema educacional. Enfim, sob a bandeira da inclusão estão práticas e pressupostos bastante distintos, o que garante um consenso apenas aparente e acomoda diferentes posições que, na prática, são extremamente divergentes. (MENDES, 2002, p. 17).

Defende-se a implantação de uma política pública que se direcione à construção de uma escola única, que se comprometa com o acesso, a permanência e a qualidade de 
ensino a todos os sujeitos que à ela se apresentam, incluindo, nesta proposição, seus professores.

Ao longo da análise da LDB, depara-se com a legitimação de uma política educacional que progressivamente tem deslocado para os municípios grande parte da responsabilidade financeira, pedagógica e administrativa no que se refere às demandas dos alunos com necessidades educacionais especiais. Uma dessas demandas é a implantação do AEE - Atendimento Educacional Especializado, tema que será abordado a seguir por se tratar da organização da política pública educacional na tentativa de garantir aos alunos com deficiência, atendimento às suas necessidades específicas.

\subsection{Educação Especial: Atendimento Educacional Especializado}

Como já colocado anteriormente, o acesso à educação é um direito humano inquestionável, e dessa forma as pessoas com deficiência, em idade de frequentá-la, não podem ser privadas deste direito. Neste alinhamento reflexivo, não se admite que aos alunos com deficiência sejam oferecidos apenas a gama de serviços da Educação Especial em substituição ao ensino regular, pois este exercício fere ao que está disposto na Constituição Federal e na LDB, lidas a partir da ratificação da Convenção sobre os Direitos da pessoa com deficiência em 2008/2009. No entanto, pelos equívocos de interpretação da LDB no que se refere ao atendimento ao aluno com deficiência, é importante apresentar o Decreto 3956 de 08 outubro de 2001, "Convenção de Guatemala", quando este trata da Convenção Interamericana objetivando eliminar todas as formas de discriminação contra as pessoas com deficiência.

Visto ser um documento do qual o Brasil é signatário, este exige a reinterpretação da LDB no que se refere ao modo de tratamento desigual aos alunos com deficiência pela modalidade da Educação Especial, quando a Convenção de Guatemala coloca que esta não deve, portanto, continuar desrespeitando as disposições da Convenção, o que direciona para a urgente necessidade da Educação Especial passar a prestar seus serviços em parceria com o sistema regular de ensino de modo a contribuir com a eliminação de toda forma de discriminação contra a pessoa com defíciência.

A Convenção de Guatemala vem a contribuir para o alargamento do conceito de Educação Especial, propondo seu redimensionamento visto que foi sempre entendida como a modalidade de ensino que podia ser substitutiva do ensino regular. 
Nessa perspectiva, defende-se um novo conceito para a Educação Especial, com a finalidade de que contribua para a perspectiva de fortalecimento e qualificação para o processo de educação inclusiva, pois se sabe que a tendência atual é que as ações educativas da Educação Especial movimentem-se de forma a promover condições aos alunos com deficiência à escolaridade, eliminando barreiras, favorecendo e qualificando a permanência destes nas salas de aula regular.

Sabe-se que as orientações introduzidas pela nova Política Nacional de Educação Especial na Perspectiva da Educação Inclusiva (que dispõe sobre o Atendimento Educacional Especializado como um dos serviços da modalidade Educação Especial que perpassa por todas as outras modalidades) ampliaram a necessidade de discussão sobre a organização das políticas públicas para a oferta deste serviço.

Entende-se atualmente que o Decreto $\mathrm{n}^{\mathrm{o}}$ 6571, que institui as Diretrizes Operacionais da Educação Especial para o atendimento educacional especializado (AEE) ofertado em salas de recursos multifuncionais, deixa claro que este atendimento não é a porta de entrada do aluno com deficiência na escola e nem mesmo pode ser pensado a partir de uma visão segregacionista como afirma Ropoli:

O AEE complementa e/ou suplementa a formação do aluno, visando a sua
autonomia na escola e fora dela, constituindo oferta obrigatória pelos sistemas de
ensino. É realizado, de preferência, nas escolas comuns, em um espaço físico
denominado Sala de Recursos Multifuncionais. Portanto, é parte integrante do
projeto político pedagógico da escola. São atendidos, nas Salas de Recursos
Multifuncionais, alunos público-alvo da educação especial, conforme estabelecido
na Política Nacional de Educação Especial na Perspectiva da Educação Inclusiva e
no Decreto N.6.571/2008. (ROPOLI, 2010, p. 19)

Este serviço tem por função oferecer ao aluno com deficiência matriculado na sala regular um apoio paralelo no contra-turno. Portanto, segundo SEESP/MEC, citado por Ropoli (2010, p. 19), o atendimento educacional especializado é um serviço da Educação Especial que "[...] identifica, elabora, e organiza recursos pedagógicos e de acessibilidade, que eliminem as barreiras para a plena participação dos alunos, considerando suas necessidades específicas".

Complementando a descrição desse atendimento, a Procuradoria Federal dos Direitos do Cidadão declara que:

O atendimento educacional especializado é uma forma de garantir que sejam reconhecidas e atendidas as particularidades de cada aluno com deficiência. São consideradas matérias do atendimento educacional especializado: Língua brasileira de sinas (Libras); interpretação de Libras; ensino de Língua Portuguesa para surdos; Sistema Braile; orientação e mobilidade; utilização de soroban; as ajudas técnicas, incluindo informática adaptada; mobilidade e comunicação alternativa/aumentativa; 
tecnologias assistidas; informática educativa; educação física adaptada; enriquecimento e aprofundamento do repertório de conhecimentos; atividades da vida autônoma e social, entre outras. (BRASIL, 2004, p. 11)

A extinta Secretaria de Educação Especial ${ }^{3}$, a partir do decreto 6571/2008, clarifica as intenções deste serviço, inclusive sinalizando seu apoio técnico e financeiro aos sistemas públicos de ensino para que estes possam não só ofertar, mas garantir o atendimento educacional especializado de forma que este seja essencialmente experimentado no formato suplementar e nunca substitutivo ao ensino regular, como indica Eugênia Augusta Favero:

Portanto, o direito ao Atendimento Educacional Especializado previsto nos artigos 58, 59 e 60 da LDBEN (Lei n ${ }^{\circ}$ 9394/96) e também na Constituição Federal, não substitui o direito à educação (escolarização) oferecida em turmas de escolas comuns da rede regular de ensino. Vale lembrar que a LDBEN utiliza as expressões 'serviços de apoio especializado na escola regular' e 'atendimento especializado' como sinônimos de Atendimento Educacional Especializado e apenas diz que este pode ocorrer em classes ou escolas especiais quando não for possível oferecê-lo em classe comum. A LDBEN não diz que a escolarização poderá ser oferecida em ambiente escolar à parte. (FÁVERO, 2007, p. 28)

Desta forma, novamente enfatiza-se que o ensino fundamental é previsto na Constituição Federal como obrigatoriedade, enquanto que o atendimento educacional especializado é um serviço de apoio que se propõe suplementar ao processo educativo do aluno com deficiência, não podendo então, ser imposto pelo sistema de ensino comum ou apresentado como condição de matrícula para o ingresso deste no ensino regular.

O atendimento educacional especializado é, portanto, uma forma de promoção da garantia de que o aluno com deficiência terá acesso a um conjunto de apoio e de recursos educacionais objetivados a minimizar as dificuldades enfrentadas a partir da sua deficiência. É importante acrescentar que este atendimento não se constitui a partir do que se costuma compreender, enquanto reforço escolar.

$\mathrm{O}$ atendimento educacional especializado pode ser ofertado tanto na própria rede regular de ensino, atendendo seu aluno no contra-turno ou também pode ser praticado pelas instituições especializadas, porém, nunca numa perspectiva de substituição ou reforço ao ensino regular.

\footnotetext{
${ }^{3}$ SECADI: Atual Secretaria de Educação Continuada, Alfabetização, Diversidade e Inclusão que tem por objetivo contribuir para o desenvolvimento inclusivo dos sistemas de ensino, direcionado a promoção da educação inclusiva e valorização das diferenças e da diversidade, através da implementação de políticas públicas educacionais articuladas com os sistemas de ensino abrangendo as áreas de alfabetização, educação ambiental, educação de jovens e adultos, educação em direitos humanos, educação especial, do campo, escolar indígena, quilombola e educação para as relações étnico - raciais.
} 
Quanto ao papel das instituições especializadas frente a este serviço, pelos dispositivos legais (Fávero, 2007, p. 33) indica que "o papel da instituição especializada é o de oferecer aos alunos com deficiência conhecimentos que não são próprios dos currículos da base nacional comum", afinal, o processo de escolaridade dos alunos com deficiência compete às escolas. Nesse alinhamento reflexivo, entende-se que quando o atendimento educacional especializado é ofertado dentro da própria escola regular a partir das salas de recursos multifuncionais (SRM), este deve ser parte integrante das discussões coletivas. Entende-se, portanto, que os alunos fazem parte da instituição escolar, e seus professores são os mesmos que participam do processo de construção do projeto político pedagógico da escola, cabendo acrescentar que, se as salas de recursos multifuncionais forem concebidas distanciadas das reflexões do coletivo, correm o risco de serem constituídas apenas como apêndices do processo educativo.

Sabe-se que ainda há muito que problematizar sobre a transversalidade da Educação Especial na perspectiva da educação inclusiva quando se entende que o desafio maior encontra-se frente à necessidade de construção de uma cultura educacional inclusiva, na qual todos os sujeitos possam participar pro ativamente do processo educativo para que este avance.

Entende-se que um dos mecanismos que podem viabilizar e qualificar essa ação é o projeto político pedagógico, como aponta as Diretrizes Operacionais para o atendimento educacional especializado a partir da resolução no 4/2009, quando no Art. 10², Brasil (2010, p. 71) afirma que "o Projeto Pedagógico da escola de ensino regular deve institucionalizar a oferta do AEE prevendo sua organização". No entanto, percebe-se que há poucos investimentos neste sentido, uma vez que as discussões sobre a implantação deste serviço, pouco têm sido problematizada, pelo coletivo escolar.

$\mathrm{Na}$ continuidade das reflexões sobre o artigo $10^{\circ}$ desta mesma resolução, é importante acrescentar que este aponta para uma organização possível das salas de recursos multifuncionais a partir da otimização de espaço físico adequado, equipado com mobiliários e materiais didáticos, garantia de acessibilidade através do uso de equipamentos específicos que possam potencializar os alunos pedagogicamente.

Além dos recursos físicos e tecnológicos, aponta-se para a necessidade de investimentos em recursos humanos como professores para o exercício da docência na sala de recurso multifuncional e outros profissionais como guia intérprete, tradutores e intérprete de Língua Brasileira de Sinais e outros que podem atuar no apoio junto às necessidades de locomoção, higiene e alimentação. 
Cabe aqui retomar que se entende que a intenção de que o atendimento educacional especializado faça parte do projeto político pedagógico das escolas, encontra-se registrada, porém não concretizada, pois a estrutura social, política e econômica não tem possibilitado que o processo educativo avance na perspectiva de cumprir sua finalidade.

Ao reconhecer que os profissionais dos sistemas de ensino enfrentam dificuldades para garantir a plena participação social e pedagógica dos alunos com deficiência, questionase o processo de formação que este serviço propõe aos professores das salas comuns, pois eles se deparam com a necessidade de mediar o conhecimento junto aos alunos com defíciência.

No âmbito da Nova Lei de Educação Especial na Perspectiva da Educação Inclusiva, sobre a questão da formação do professor que atua na escola regular de ensino, Brasil (2007) aborda o tema superficialmente, de maneira imprecisa e vaga.

Compondo com esta reflexão, Abreu e Carvalho (2011, p. 2) declaram que "na história das políticas de educação [...] a abordagem do tema caracteriza-se pela imprecisão, pela descontinuidade de alternância de posições favoráveis à formação do professor especialista ou do professor generalista". Dessa forma, o esvaziamento das discussões sobre a formação dos profissionais da educação suprime as possibilidades de superação dos desafios enfrentados no cotidiano escolar junto aos alunos com deficiência.

O Decreto $N^{o}$ 6.571, de 17 de Setembro de 2008, que dispõe sobre o atendimento educacional especializado, regulamenta o parágrafo único do art. 60 da Lei no 9.394, de 20 de dezembro de 1996, e acrescenta dispositivos ao Decreto $\mathrm{n}^{0} 6.253$, de 13 de novembro de 2007, indicando a obrigatoriedade de investimentos das políticas públicas na implantação de serviços que se direcionem a atender as necessidades dos profissionais da educação que estarão atuando junto ao aluno com deficiência declarando que:

Art $2^{\circ}$ : São objetivos do atendimento educacional especializado:

I - prover condições de acesso, participação e aprendizagem no ensino regular [...]

II - garantir a transversalidade das ações da educação especial no ensino regular

III - fomentar o desenvolvimento de recursos didáticos e pedagógicos que eliminem as barreiras no processo de ensino e aprendizagem [...] (BRASIL, 2010, p. 27)

$\mathrm{O}$ artigo $3^{\circ}$ do Decreto $N^{\circ}$ 6.571, de 17 de Setembro de 2008, sinaliza inclusive que o Ministério realizará investimentos financeiros para que sejam articuladas ações no sentido de formar os professores das salas comuns declarando a importância e necessidade de investimentos na "formação de gestores, educadores e demais profissionais da escola para a educação inclusiva”. (BRASIL, 2008, p. 1). 
Ao entender que o Atendimento Educacional Especializado enquanto serviço da Educação Especial objetiva-se a suplementar as necessidades advindas das demandas das deficiências, defronta-se com a expectativa de que esse possa vir a garantir ações que potencializem os recursos dos alunos para que possam usufruir da escola regular acessando seu direito a educação. Dessa forma, compreende-se que o atendimento educacional especializado poderá agregar conhecimentos específicos ao ensino regular, uma vez que, participando do processo de formação contínua, os professores e demais profissionais da escola poderão promover ações educativas que equiparem oportunidades a todos os alunos, incluindo nesta proposição, os alunos com dificuldades de aprendizagem.

Entende-se que o processo de escolarização é um direito constitucional, no entanto, o desafio tem sido em garantir não somente o acesso, mas, como já colocado anteriormente, tem-se enfrentado barreiras que precisam ser superadas para que se possa garantir ao aluno com deficiência e a todos seus pares, a permanência e o uso deste espaço escolar com qualidade, pois, em conformidade com Morais:

[...] embora a conscientização para a necessidade de modificação de atitudes e práticas escolares seja um passo necessário, apenas uma ação consciente e organizada - que leve à conquista de melhores condições de trabalho e de uma política satisfatória de recursos humanos nos setores da saúde e educação, e a vontade da sociedade e de seus dirigentes de reverterem o quadro atual e de melhorarem a qualidade destes serviços - trará mudanças significativas ao panorama educacional brasileiro. (MORAIS, 1997, p. 186)

$\mathrm{Na}$ perspectiva de ações que visem mudanças significativas junto ao processo educacional inclusivo, o atendimento educacional especializado é só mais uma das ações que precisam ser desencadeadas pelas políticas públicas quando se aponta a necessidade e importância de investimentos no processo de formação de seus professores, de modo a potencializar as reflexões que se direcionem objetivando a construção de uma cultura educacional inclusiva.

Sabe-se que, sendo determinado pelos objetivos e pelas condições concretas às quais se aplica o atendimento educacional especializado, não é um serviço formatado e idealizado, pronto a ser aplicado, mas implica num serviço que precisa ser concebido a partir do processo de participação e colaboração recíproca entre todos os envolvidos, pois, nessa perspectiva, entende-se que o atendimento educacional especializado pode vir a contribuir para o processo educacional inclusivo. 
Dessa forma, o tema será abordado no próximo capítulo buscando analisar sua constituição a partir de um processo educacional entendido como direito de todos os alunos; com ou sem deficiência. 


\section{EDUCAÇÃO INCLUSIVA OU EDUCAÇÃO PARA TODOS?}

De acordo com o dicionário Aurélio (2004), inclusão significa "pertencimento; fazer parte; configurar e pertencer junto ao outro”. Se inclusão significa pertencimento, reincidentemente voltamos a uma problemática: há muitos desafios a serem enfrentados e analisados para que se atinja a educação como direito de "todos".

Ao problematizar o conceito de inclusão, reporta-se pensar sobre o processo de exclusão, seu contexto e significado. Então surge um questionamento que se faz necessário para se entender de que maneira esse processo se evidencia no campo da educação. Por que se dá este movimento excludente na escola, espaço que essencialmente deveria ser inclusivo, de qualidade para todos? Barroco nos conduz à reflexão declarando que:

Entendo que, ao se falar ou se trabalhar com proposta de educação e de sociedade inclusivas, é necessário reconhecer que essa defesa ganhou evidência na década de 1990, fazendo uma convocatória justificável de novos comportamentos. Entretanto isso não se refere a um novo paradigma, posto que é decorrente da própria lógica excludente do capital. (BARROCO, 2007, p. 159)

Cabe analisar que, ao reportar-se aos aspectos educacionais inclusivos, somos conduzidos a acrescentar que se entende que uma parcela significativa dos alunos com ou sem deficiência que acessam a escola está excluída justamente pela estrutura social na qual está submetida dentro da sociedade de classes. Segundo Barroco:

Desde o século XIX, a exclusão em todas as suas formas, inclusive no plano
educacional, era prevista e planejada, levando Marx e Engels a estarem atentos a
toda e qualquer possibilidade de ação transformadora da sociedade naqueles anos.
Todavia tinham clareza de que as idéias da classe economicamente dominante
também era o espírito dominante da época. Não entendiam que a proposta liberal da
educação única para todos deveria ser defendida, ainda que seus princípios fossem
aparentemente de supressão de barreiras econômicas, jurídicas, raciais, religiosas,
etc., que impediriam o livre acesso das crianças e jovens a educação, de acordo com
suas capacidades e aptidões. No entendimento dos autores, seria inalcançável tal
supressão no âmbito da sociedade burguesa, por entrar em conflito com o estado
econômico vigente. Os interesses diametralmente opostos das classes antagônicas
iriam entrar em choque; e a classe detentora do monopólio econômico não abriria
mão de fazer prevalecer também o monopólio econômico sobre a cultura.
(BARROCO, 2007, p. 170)

Nesse direcionamento, este capítulo apresenta algumas reflexões ao problematizar os conceitos de exclusão e inclusão enquanto produção da sociedade capitalista, pois se sabe que nas últimas décadas, a consciência do direito à educação avançou, no entanto a escola continua sendo uma instituição seletiva na medida em que a cultura da exclusão encontra-se objetivada na sua formatação e na estrutura do sistema escolar. 
Ao organizar o conjunto de reflexões acerca da educação inclusiva, aborda-se o agravamento da dualidade da escola pública que reproduz as desigualdades sociais, pois a mesma desde as décadas de 80 e 90, segundo Libâneo (2012), caracterizou-se como sendo a escola do acolhimento social para os pobres e escola do conhecimento para os ricos.

\subsection{Inclusão e Exclusão como Produção Social}

Para abordar tal temática no campo educacional é necessário resgatar o processo histórico anunciando que as reformas educativas tiveram início na década de 80 na Inglaterra. Essas reformas desencadearam acordos internacionais em torno do movimento denominado como Educação para Todos, sendo válido destacar que a Conferência Mundial sobre a Educação, realizada em 1990, em Jomtiem, é seu marco, pois, segundo a Declaração Mundial sobre Educação para todos, é fato que:

Durante a década de 80 , esses problemas dificultaram os avanços da educação básica
em muitos países menos desenvolvidos. Em outros, o crescimento econômico
permitiu financiar a expansão da educação, mas, mesmo assim, milhões de seres
humanos continuam na pobreza, privados de escolaridade ou analfabetos. E em
alguns países industrializados, cortes nos gastos públicos ao longo dos anos 80
contribuíram para a deterioração da educação. (UNESCO, 1998, p. 2)

Ao colocar os grandes desafios da década de 80 frente ao sistema educacional, a Declaração Mundial sobre Educação para Todos manifesta a indignação quanto aos índices de pobreza que geram desprivilegiados e analfabetos diante do sistema educacional. A mesma declaração relembra que, há mais de quarenta anos, as nações do mundo afirmaram na Declaração Universal dos Direitos Humanos (UNESCO, 1998, p. 2) que "toda pessoa tem direito à educação".

Com o manifestado na Declaração Universal dos Direitos Humanos, sabe-se que um passo importante foi dado; no entanto, após decorridos 64 anos, os direitos universais à educação de qualidade permanecem assegurados nas leis que foram sendo estabelecidas, enquanto que no cotidiano escolar aqueles que participam da escola e vivem suas mazelas, sustentam que o debate precisa ser intensificado para que as leis deixem de existir somente no seu aspecto formal. De acordo com a Declaração Mundial sobre Educação para Todos, após quatro décadas:

[...] apesar dos esforços realizados por países do mundo inteiro para assegurar o direito à educação para todos, persistem as seguintes realidades: mais de 100 milhões de crianças, das quais pelo menos 60 milhões são meninas, não têm acesso ao ensino primário: mais de 960 milhões de adultos - dois terços dos quais mulheres 
- são analfabetos, e o analfabetismo funcional e um problema significativo em todos os países industrializados ou em desenvolvimento: mais de um terço dos adultos do mundo não têm acesso ao conhecimento impresso, às novas habilidades $\mathrm{e}$ tecnologias, que poderiam melhorar a qualidade de vida e ajudá-los aperceber e a adaptar às mudanças sociais e culturais: e mais de 100 milhões de crianças e incontáveis adultos não conseguem concluir o ciclo básico, e outros milhões, apesar de concluí-lo, não conseguem adquirir conhecimentos e habilidades essenciais. (UNESCO, 1998, p. 2)

Nesse contexto histórico, é necessário analisar e problematizar as associações realizadas, pois as políticas educacionais do Banco Mundial para os países em desenvolvimento sinalizaram interesses que colocaram a escola pública em destaque na sociedade. No entanto, esta mesma sociedade identifica a escola pública enquanto instituição com a missão do acolhimento social. Libâneo, ao comentar o assunto, afirma que:

[...] tem-se observado nas últimas décadas contradições mal resolvidas entre quantidade e qualidade em relação ao direito à escola, entre aspectos pedagógicos e aspectos socioculturais, entre uma visão de escola assentada no conhecimento e outra nas suas missões sociais. (LIBÂNEO, 2012, p. 15)

Segundo o autor, a escola é impactada com os desvios de sua função, passando a ser interpretada enquanto procedimento técnico a serviço do desenvolvimento e das competências que multiplicariam a competitividade entre os sujeitos.

Nesse movimento, as políticas educacionais abordam a função da pedagogia, como sendo um conjunto de técnicas que podem instrumentalizar as crianças para que no futuro, possam ser trabalhadores competentes. Angelucci denuncia esta intenção declarando que:

É assim que a política educacional ingressa na rota do engodo, posto que vende a ilusão de ascensão social e de empregabilidade. Constroem-se estatísticas que falem de inclusão escolar e de sucesso da política educacional, que vendam uma imagem positiva do país no exterior, que mantenham internamente a ilusão de que se está superando a 'crise' que o país atravessa, e que gerem dividendos para os governantes. Para tanto, aposta-se em programas de correção de fluxo escolar, que têm como principal objetivo baratear o financiamento da educação pelo Estado, fazendo com que a maior parte do alunado chegue ao final da escolarização básica o mais rápido possível, não importando a qualidade do ensino oferecido. (ANGELUCCI, 2011, p.197)

Entende-se que diversos fatores, ao longo das últimas décadas, distanciam a escola da sua função social. Diante do quadro denunciado, é fato que a educação está pautada no princípio da qualificação da mão de obra do futuro trabalhador. Segundo Libâneo (2012), outro aspecto que merece destaque é o movimento que distancia a escola de ser o espaço do conhecimento para ser transformada no espaço do acolhimento, de integração social. Tal 
espaço, que para muitos é denominado espaço inclusivo, distancia-se da atividade educacional e de sua função social.

Essas tentativas se intensificaram nas décadas de 80 e 90, pois, segundo Libâneo (2012, p.16), "nas políticas oficiais, surge a escola do acolhimento social, cuja função é propiciar a convivência e a sociabilidade, em contraponto à escola destinada, preponderantemente, à formação cultural e científica, isto é, ao conhecimento e ao ensino".

As reflexões sobre a função da escola têm sido frequentes aos que acompanham e analisam a educação na escola pública, pois esta evidencia um quadro crítico que denuncia o esvaziamento da sua função social na atual sociedade. Portanto, é necessário compreender os fenômenos educacionais na tentativa de indicar caminhos para a superação do que está instituído socialmente. O pensamento crítico daqueles que cotidianamente vivem na escola deve buscar compreender os fatos, resgatando as finalidades da educação.

Ao problematizar o processo de inclusão e exclusão enquanto produção social determinada pela sociedade de classes, não se pode deixar de acrescentar que o fracasso educacional tem sido expressão do cotidiano escolar que, predominantemente, está direcionado às crianças e adolescente pobres, ou seja, aquelas cujas condições para aprender ou não são determinadas pelos padrões da cultura dominante. Ao adentrar a escola e acompanhar o cotidiano, vê-se o quanto a política pública educacional tem distanciado dos filhos dos trabalhadores a possibilidade de emancipação a partir da apropriação do conhecimento. Segundo Angelucci:

O fenômeno da exclusão também está presente no interior das escolas: se a forte defasagem entre as crianças de 8 anos atinge o percentual de $5,25 \%$, a partir dos 9 anos, esse percentual aumenta vertiginosamente: 9 anos: 20,4\%, 10 anos: 29,9\%, chegando, para os jovens de 14 anos a 45,9\% e mantendo-se na faixa de 36 a $44 \%$ até os 17 anos. (ANGELUCCI, 2011, p. 197)

A exclusão dentro e fora da escola revela que esse fenômeno social refere-se ao grupo de alunos socialmente considerados carentes, uma vez que, de maneira equivocada, acredita-se que as origens do problema que eles apresentam na fase escolar encontram-se nos próprios alunos, justificados a partir de suas experiências e de seus ambientes que não potencializam e não transmitem os padrões culturais necessários para que tenham um bom desempenho frente às demandas da escola e da sociedade em geral.

O fato, é que mesmo estando na escola, somente o acesso a ela não garante a apropriação do conhecimento, portanto não se pode considerar que a garantia de matrícula, 
em atendimento a uma exigência legal, possa vir a ser o reconhecimento da garantia do direito a educação. Prieto (2006), ao se posicionar sobre o tema, afirma que:

\begin{abstract}
As instituições escolares, ao reproduzirem constantemente o modelo tradicional, não têm demonstrado condição de responder aos desafios da inclusão social e do acolhimento as diferenças, nem de promover aprendizagens necessárias à vida em sociedade, particularmente nas sociedades complexas do século XXI. [...] Essa escola não tem dessa maneira, conseguido se configurar como espaço educativo para significativo contingente de alunos independente de apresentarem ou não necessidades denominadas como educacionais especiais. (PRIETO, 2006, p. 33)
\end{abstract}

Diante dessa constatação, uma necessidade deve ser considerada e analisada: a identificação dos mecanismos e ações que precisam ser articulados e aprimorados para que de fato as escolas se tornem espaço de ensino e de aprendizagem para todos os alunos, indistintamente. Por si só, as políticas públicas direcionadas à inclusão denunciam a exclusão do próprio sistema, e Libâneo nos conduz nessa reflexão, colocando que:

Com o apoio em premissas pedagógicas humanistas, concebeu-se uma escola que primasse, antes de tudo, pelas diferenças psicológicas de ritmo de aprendizagem, pelo respeito às diferenças sociais e culturais, de flexibilização das práticas de avaliação escolar, tudo em nome da intitulada 'educação inclusiva'. (LIBÂNEO, 2012, p. 17)

Não que esses aspectos que diferenciam os sujeitos tenham que ser desprezados, mas entende-se que o problema está na distorção dos reais objetivos da escola. Essa constatação nos impulsiona a acrescentar que as ações direcionadas às escolas são fragmentadas, uma vez que as políticas públicas focam prioritariamente à intervenção sobre a educação inclusiva para os alunos com deficiência. Não é contemplada uma análise mais aprofundada da problemática em questão no que diz respeito à função social da escola como um todo e para todos. O que se problematiza é a urgente necessidade de articulação das políticas públicas no sentido de intensificar o aprimoramento das propostas pedagógicas, não só para os alunos com deficiência, mas no direcionamento da qualificação da escola pública para todos.

Diante da reflexão sobre a inclusão escolar, não se pode deixar de expressar o entendimento de que os alunos vêm tendo acesso à escola; no entanto, muitos deles permanecem fracassando frente a um sistema que permite especializar-se para poucos, e se distancia do cumprimento do seu papel enquanto provedor de direitos de muitos outros ou, porque não dizer, de todos. Segundo Barroco:

O drama desta maioria, a quem o pão e o teto não são assegurados, encaminha para a precariedade de mediações significativas para que a aprendizagem escolar e não - 
escolar se efetive. Não é difícil imaginar as dificuldades que encontra para participar da vida escolar que deveria ser o essencial: a aquisição do conhecimento científico. Considerando a teoria de Vygotski (1997), pode-se dizer que o desenvolvimento da grande parcela de indivíduos não se movimenta como poderia, posto que a aprendizagem lhes é dificultada ou negada. (BARROCO, 2007, p. 162)

A partir da análise crítica expressada pela autora, verifica-se que a escola é a manifestação da fragilidade das relações que se estabelecem no processo de desenvolvimento daqueles alunos, pois, para muitos, a escola se transforma num espaço segregacionista, porque não dizer seletista.

Diante dessa constatação, pode-se afirmar que estar na escola e não se apropriar do conhecimento trata-se de um processo de exclusão em sua forma mais dramática, pois, matriculados, os alunos permanecem na escola, e dela saem sem se apropriar do que lhes é necessário para emancipar-se. Segundo Libâneo:

\footnotetext{
A luta pela escola pública obrigatória e gratuita para toda a população tem sido bandeira constante entre os educadores brasileiros, sobressaindo temas sobre as funções sociais e pedagógicas como a universalização do acesso e da permanência, o ensino e a educação com qualidade, o atendimento às diferenças sociais e culturais, a formação para a cidadania crítica. [...] Ressalte-se, também, a circulação de significados muito difusos do termo 'qualidade de ensino', seja por razões ideológicas, seja pelo próprio significado que o senso comum atribui ao termo dependendo do foco de análise pretendido: econômico, social, político, pedagógico, etc. (LIBÂNEO, 2012, p. 15)
}

A intenção em problematizar as proposições emanadas das políticas públicas para a educação inclusiva no contexto da educação para todos ocorre pelo fato de que as ações praticadas dentro da escola não estão contribuindo para o aprimoramento dos processos regulares de escolarização. Conforme Libâneo (2012, p. 15), “tem-se observado nas últimas décadas contradições mal resolvidas entre quantidade e qualidade em relação ao direito à escola, entre aspectos pedagógicos e aspectos socioculturais, entre uma visão de escola assentada no conhecimento e outra nas suas missões sociais”. A partir dessa afirmação, identificam-se os processos de inclusão e exclusão como produtos da sociedade capitalista.

A necessidade de se repensar a educação como sendo direito de todos para que se torne inclusiva se faz urgente na medida em que se expandem e fortalecem concepções contraditórias. Segundo Eidt e Tuleski (2007, p. 243), “aprende-se a pensar de forma fragmentada numa sociedade que dissocia, aliena e isola, mais do que une e relaciona" e neste movimento, as concepções vão se formatando e sendo projetadas na escola e na sociedade.

Nessa perspectiva, sabe-se que o Estado precisa gerir os conflitos entre os interesses das diferentes classes sociais. Para tanto, a escola pública se configura como uma 
instituição que pode ser instrumento de manobra para a manutenção das relações de poder. Sobre tal aspecto, Prieto (2006, p. 33) declara que "no plano ético e político, a defesa de sua igualdade de direitos, com destaque para o direito à educação, parece constituir-se um consenso. As discordâncias são anunciadas no plano da definição das propostas para sua concretização".

Em conformidade com o exposto, compreende-se que a cultura da exclusão da sociedade prevalece e tem fortalecido dentro das escolas. Nesse sentido, Libâneo afirma que:

Ao substituir a escola destinada à formação cultural e científica pela escola do acolhimento social, ocorre o ocultamento da dimensão cultural e humana da educação, à medida que se dissolve a relação entre o direito das crianças e jovens de serem diferentes culturalmente e, ao mesmo tempo, semelhantes (iguais) em termos de dignidade e reconhecimento humano. (LIBÂNEO, 2012, p. 23)

Em concordância com o autor, reconhece-se que a sociedade, ao categorizar a escola, enquanto acolhedora e inclusiva, obscurece o fato de que educacionalmente estamos todos excluídos. A tentativa de fazer acreditar que dentro da escola todos se enquadram, todos pertencem a ela e dela participam, distancia a possibilidade de avaliação do sistema como um todo, contribuindo com os interesses da classe dominante. Tal fato implica na permanência e reiteração do estado das coisas, sem que sejam criadas condições objetivas para a transformação da educação e da sociedade. Angelucci contribui com esta reflexão ao afirmar que:

Cada indivíduo é incitado a dar o melhor de si, qualificar-se, superar a si próprio e aos outros, sob o argumento de que aos melhores estarão asseguradas as grandes oportunidades de trabalho. Os demais - tidos como 'despreparados', 'incompetentes', - estão condenados à 'exclusão'. É neste jogo que o homem se encontra; dito excluído da sociedade, é objeto de 'inclusão social' que na verdade, só fazem encobrir a realidade de que é absolutamente necessário que ele se sinta sempre do lado de fora, mas com toda a possibilidade de 'entrar' e 'fazer' parte da sociedade, desde que tenha competência para tanto. (ANGELUCCI, 2011, p. 193)

Ao considerar a abrangência do assunto, voltam-se as reflexões ao fato de que, em sendo uma escola para todos, o termo "necessidades educacionais especiais" se destina ao aprimoramento das ações pedagógicas voltadas a diferentes categorias de alunos, sendo eles, alunos com deficiência, com dificuldades de aprendizagem ou todos os outros que acessam a escola. Afirmando que a escola inclusiva é aquela para "todos", novamente nos depararemos com uma questão que ultrapassa o problema do acesso e das características dos sujeitos direcionando-se às concepções e aos objetivos dessa escola. A respeito disso, Barroco afirma que: 
Professores, alunos e pais, adjetivados das mais diferentes maneiras (confusos, interessados, desmotivados, agressivos, coerentes, estudiosos, etc.), têm estabelecido relações interpessoais nada educativas, posto que não têm levado a um estado de maior consciência a respeito de si mesmos e do mundo - algo fundamental ao se supor que os indivíduos se constroem paralelamente à construção que fazem do mundo, humanizando-o e a si próprios. (BARROCO, 2007, p. 160)

A educação que se propõe à inclusão de todos encontra como desafios não só a necessidade de revisão de suas concepções teórico metodológicas, como também a necessidade de repensar a formação dos professores. Segundo Gadotti (1985, p. 61), “os educadores foram reduzidos a meros executores de uma política traçada em gabinetes". Portanto, ao declarar que inclusão é pertencimento, não se pode esquivar de problematizar o papel do professor e sua práxis frente ao processo, pois o professor é um dos sujeitos que precisa ser incluído nessa dinâmica.

Entende-se, nessa perspectiva, que, diante dos desafios advindos das necessidades educacionais especiais, as políticas públicas para a educação devem favorecer o processo, potencializando o sistema como um todo, de forma que este articule suas ações voltadas às ações educativas sem levar em conta exclusivamente os aspectos de deficiência.

Sendo assim, a partir da elaboração do Projeto Político Pedagógico, a escola deve problematizar e intensificar sua análise frente aos modos de ensinar e de aprender dos que estão envolvidos no processo, pois se entende a importância da escola para os alunos com ou sem deficiência, devido à transformação da sociedade pela transformação dos indivíduos ser um dos produtos da atividade pedagógica. Partindo dessa análise, Barroco (2007, p. 160) coloca que "certamente, o empenho da psicologia e da pedagogia, sob uma perspectiva crítica, é a luta para que a primeira forma de participação, de apropriação, fruição e uso fruto seja acessível a todos".

Portanto, é válido reafirmar que a educação deve proporcionar a todos o acesso ao que o homem tem produzido historicamente, conduzindo-os às reflexões de maneira crítica e ética, objetivando, assim, a emancipação dos sujeitos.

Nesse sentido, é necessário questionar as políticas públicas de educação e o que estas vêm promovendo na condução do favorecimento e da potencialização dos seus profissionais uma vez que se coloca para a educação que esta tem que se ajustar para atender a diversidade. Nesse direcionamento, é preciso acompanhar e questionar as ações desencadeadas de forma que se possa avançar na busca pela superação do que está posto pelo sistema de classes. Segundo Barroco: 
A lógica da exclusão - que decorre e que, ao mesmo tempo, leva a dada conformação das relações sociais que imprimem determinados valores e práticas que fazem do homem um homem desse tempo, precisa, ainda, ser mais abordada e compreendida, subsidiando as propostas de intervenções pedagógicas voltadas para os interiores das salas de aula. (BARROCO, 2007, p. 160)

Reafirma-se que este estudo não tem como objetivo defender a escola inclusiva no foco da deficiência, mas busca analisar a escola onde o ensino regular de "qualidade" possa ser oferecido a todos indistintamente. Percebe-se que, mesmo com todos os percalços, o conceito de necessidades educacionais especiais evoluiu nas últimas décadas, pois anteriormente esse conceito possibilitava pensar a deficiência, e hoje se refere à amplitude das diferenças individuais que podem se dar por padrões culturais, habilidades e capacidades diferentes.

É notório que a discussão em torno da "educação inclusiva" se intensifica na medida em que por força da lei, os sistemas de ensino começam a matricular, em suas redes, alunos com deficiência. Barroco enriquece esse posicionamento quando propõe pensar que:

É nesse momento histórico em que 'tudo parece estar impregnado do seu contrário' que é preciso falar dos avanços conquistados, mas também da exclusão gerada; da necessidade de bom atendimento escolar para todos, incluindo os indivíduos com deficiências; da necessidade da igualdade ser tratada com a igualdade e da desigualdade ser tratada como diferença, e das dificuldades que isso engendra. (BARROCO, 2007, p. 164)

É fato que nas últimas décadas o termo inclusão tornou-se recorrente nas políticas públicas e na literatura das ciências sociais. Se perguntarmos quem são os alunos excluídos da rede pública de ensino, como resposta a sociedade nos colocará que excluídos do sistema estão aqueles com deficiência. Ainda assim, com todas as evidências excludentes denunciadas pelo que se objetiva na escola, a sociedade ratifica o discurso hegemônico da inclusão educacional por intermédio da atual política pública, sendo necessário problematizar as contradições advindas desse processo. Segundo Angelucci:

O acompanhamento cuidadoso do dia-a-dia escolar revela o quanto a atual política educacional tem conduzido ao esfacelamento do espaço público, da garantia do direito à educação com qualidade, da dignidade de trabalhadores e usuários da educação, causando perplexidade a implantação de medidas inclusivas referentes a uma população historicamente expropriada de seus direitos. Instala-se aí uma aparente contradição que merece atenção daqueles que procuram contribuir para a garantia, de fato, do direito universal à educação. (ANGELUCCI, 2011, p. 189)

Entende-se que na sociedade contemporânea, com o denominado processo de democratização, as crianças têm o acesso à escola, mas a exclusão revela-se de modo mais 
sutil, embora não menos violento: a permanência nas escolas, por longos períodos de tempo, de crianças que nunca chegam a se apropriar de fato dos conteúdos escolares. Esta pode ser considerada a forma mais dramática de exclusão. Sobre esse aspecto, Angelucci (2011, p. 193) afirma que "o jogo tem por objetivo que o homem continue, como sempre, incluído na lógica do sistema social, só que em um lugar que permita que o estado das coisas não se altere significativamente".

Nessa inquietação, objetivando contribuir para o avanço do debate, vamos destacar os princípios colocados pela Declaração de Salamanca. A opção pela análise de fragmentos do seu conteúdo se dá por tratar-se de um documento importante quando sua diretriz não nega as características individuais dos sujeitos, mas que se projeta para além das deficiências e das dificuldades de aprendizagem, ao problematizar a educação de qualidade na rede regular de ensino como direito de todos.

\subsection{A Declaração de Salamanca e os Princípios Educacionais Inclusivos}

Sendo o Brasil um dos signatários da Declaração de Salamanca, cabe embasar as discussões a partir do seu teor por concluir que se trata de um documento que se pauta nos princípios da equidade, quando, em Junho de 1994, é redigida, manifestando o direito de todas as pessoas à educação, afirmando que a diferença é própria da humanidade, não podendo ser fator de discriminação.

A Declaração de Salamanca, a partir da abrangência dos seus princípios acerca da concepção de educação inclusiva, torna-se inovadora na medida em que seu próprio texto propõe a organização da Educação Especial dentro da estrutura de uma educação para todos, ou seja, no sistema regular de ensino. A esse respeito, tal declaração indica que:

[...] reafirmamos, por este meio, o nosso compromisso em prol da Educação para Todos, reconhecendo a necessidade e a urgência de garantir a educação para as crianças, jovens e adultos com necessidades educativas especiais no quadro do sistema regular de educação [...]. (UNESCO, 1994, p. 8)

É necessário destacar que a Declaração de Salamanca advém da necessidade de reafirmar a importância da educação para todos, pois se manifesta numa década quando o processo educacional está em franca transformação, a partir dos interesses capitalistas. Dessa 
forma, fizeram-se necessárias reflexões que conduzissem problematizar a educação a partir da dimensão social, política, cultural e econômica, e as manifestações de exclusão a partir dessas dimensões. Garcez (2004, p. 121) afirma que "a dialética inclusão/exclusão reflete um processo histórico em constante transformação, que se objetiva nas ações individuais e coletivas no cotidiano da sociedade".

Sabe-se que a criação de leis, de certo modo, sinaliza uma preocupação dos legisladores em construir documentos que dêem conta dos anseios da sociedade. Com a Declaração de Salamanca não foi diferente, pois, quando realizada em 1996, ratifica o ideal já proposto na Declaração dos Direitos Humanos, reafirmando assim o direito de toda pessoa à educação. Sobre esse aspecto, a Declaração proclama que:

- cada criança tem o direito fundamental à educação e deve ter a oportunidade de conseguir e manter um nível aceitável de aprendizagem,

- cada criança tem características, interesses, capacidades e necessidades de aprendizagem que lhe são próprias,

- os sistemas de educação devem ser planeados e os programas educativos implementados tendo em vista a vasta diversidade destas características e necessidades,

- as crianças e jovens com necessidades educativas especiais devem ter acesso às escolas regulares, que a elas se devem adequar através duma pedagogia centrada na criança, capaz de ir ao encontro destas necessidades,

- as escolas regulares, seguindo esta orientação inclusiva, constituem os meios mais capazes para combater as atitudes discriminatórias, criando comunidades abertas e solidárias, construindo uma sociedade inclusiva e atingindo a educação para todos; além disso, proporcionam uma educação adequada à maioria das crianças e promovem a eficiência, numa ótima relação custo-qualidade, de todo o sistema educativo. (UNESCO, 1994, p. 8)

Dessa forma, a importância da Declaração de Salamanca se dá enquanto documento consensuado por 92 países e 25 organizações internacionais, sendo o conteúdo da sua redação imprescindível nas discussões da sociedade civil e do governo nacional. Ela discute a educação como sendo a estratégia necessária para satisfazer as necessidades básicas de aprendizagem, reafirmando a sua importância quando declara que a escola tem papel fundamental na disseminação e construção do conhecimento.

Reincidentemente, retoma-se o grande desafio colocado à escola, pois muito tem se discutido sobre a escola inclusiva como sendo aquela que matricula alunos com deficiência na sala regular de ensino, no entanto, na busca por analisar o papel do Estado diante dos sujeitos que se apresentam a ela, faz-se necessário problematizar não somente a inclusão educacional do aluno com deficiência, mas também a inclusão de todos os alunos 
independente de suas características, como proposto pela Declaração de Salamanca. Sobre este tema, Garcez afirma que:

\begin{abstract}
Esse documento indica que os governos locais devem estabelecer com maior prioridade, tanto política como financeira, o aprimoramento dos sistemas de ensino para se tornarem aptos a incluírem todas as crianças. Essa é a referência mais concreta da mudança de paradigma de integração para inclusão, pois propõe uma mudança social para que seja possível lidar com toda diversidade humana, e não uma adaptação do indivíduo ao padrão considerado de normalidade. Por esse motivo, a Declaração de Salamanca pode ser considerada um divisor de águas como perspectiva de acesso à educação elaborada para um grupo que, historicamente, tem sido excluído, pois caminha no sentido oposto ao da classificação e patologização do indivíduo, privilegiando uma leitura da deficiência como diferença, e dessa como inerente à condição humana. (GARCEZ, 2004, p. 44-45)
\end{abstract}

Como cita a autora, trata-se da necessidade de uma análise do sistema como um todo, objetivando a transformação social. As leis que se colocam na direção de garantia aos direitos desses sujeitos nos remetem a questionar seu cumprimento quando o que vem sendo evidenciado no contexto escolar em consonância com as ações desencadeadas pelas políticas públicas de educação, manifestam as condições precárias de formação e de trabalho do professor, assim como evidenciam que os alunos não estão se apropriando do conhecimento. O que se verifica é que os sujeitos que se apresentam à escola, estão no exercício de uma prática educativa alienada.

Entende-se, portanto, que para contribuir com o debate sobre a importância da escola pública e sua função social, não se trata de defender a escola especial ou a escola inclusiva, mas de provocar pensar as crescentes demandas educacionais da escola regular que devem ser de qualidade para todos.

Dessa maneira, buscando alinhar as reflexões sobre inclusão e exclusão, também a partir dos sujeitos com deficiência, é importante contextualizar brevemente a conjuntura das escolas especiais. Não se pode deixar de mencionar que o alargamento das discussões na busca pela ampliação do direito à educação das camadas excluídas da escola ganhou força na década de 70, com o debate sobre a democratização do ensino, ocasião em que as pressões da população tornaram-se mais intensas, visto à disseminação do pensamento de que a ascensão social estava aliada ao processo educacional.

Ao propor pensar a escola de qualidade para todos, torna-se necessário buscar elementos que ajudem a analisar as amarras que se constituíram fortalecendo o caminho inverso. Sabe-se, através dos registros da década de 70, que houve um crescimento exponencial do número de alunos em atendimento segregado com a criação de classes 
especiais em escolas regulares em todo o território nacional. Carneiro (1997, p. 132), afirma que "neste processo de exclusão, a educação especial cumpre um papel relevante, na medida em que ela representa uma alternativa de atendimento àqueles alunos considerados incapazes de freqüentar escola comum".

Embora essas salas especiais inicialmente tenham sido concebidas como estratégicas para recebessem apenas alunos com deficiência intelectual, passaram a receber também grande número de alunos que apresentavam dificuldades de aprendizagem e/ou problemas de comportamento, alunos estes oriundos das camadas mais pobres da população que evidenciaram processo seletivo do capitalismo via escola, pois:

O caráter eletista, meritocrático, homogeneizador e competitivo das escolas oprimem o professor e o reduz a uma situação de isolamento e impotência, principalmente frente aos seus alunos com deficiência mental [...]. Diante disso, a saída encontrada pela maioria desses professores é desvincilhar-se desses alunos que não acompanham as turmas, encaminhando-os para qualquer outro lugar que supostamente entenda como ensiná-los. O número de alunos categorizados como deficientes mentais foi ampliado enormemente, abrangendo todos aqueles que não demonstravam bom aproveitamento escolar e com dificuldades de seguir as normas disciplinares da escola. (BATISTA, 2007, p. 12)

Esses passaram a fazer parte do grupo de alunos público alvo da educação especial, que, dentro das escolas regulares, os mantinham separados dos demais.

Dessa forma, a ampliação de vagas no ensino especial se intensificava e manifestava-se enquanto elemento seletivo promovido pela própria escola, chamando atenção para a cultura do estigma, da segregação e da exclusão das camadas populares e seus prejuízos frente o rendimento escolar. Nessa mesma década de 70, a exclusão de alunos já nas séries inicias da rede pública por diferentes motivos como evasão, falta de acesso e ou repetência, denunciaram que esses alunos, enquanto fracassados, eram tidos como portadores de algum problema não cabendo à escola resolver pois, o fracasso era identificado e justificado no próprio sujeito como aponta Batista:

Entendia-se que estes alunos necessitavam de condições escolares especiais o que incluía currículos e ensino adaptados, número menor de alunos por sala, professores especializados e outras condições particulares de organização pedagógica do processo educacional. Assim sendo, dada a essa composição específica, a escola especial sempre enfrentou o impossível: substituir adequadamente o compromisso da escola comum. (BATISTA, 2007, p. 8)

É necessário destacar que equivocadamente, frente à constatação do fracasso escolar, o aluno é identificado como sendo o responsável pelos seus déficits no processo de escolarização, o que ainda abre possibilidades para o encaminhamento dos mesmos à serviços 
considerados compensatórios como apoio, reforço escolar e até mesmo às salas especiais. Nesta dinâmica, a pedagogia, de maneira não consciente, reforça a cultura do fracasso e da exclusão incrustando-a na organização do próprio sistema educacional.

Diante dessa manifestação, surgem questões que precisam ser problematizadas para que se possa avançar nas reflexões sobre as causas da exclusão e suas manifestações na escola. Entendendo que alunos com e sem deficiência foram encaminhados às salas especiais, é necessário questionar sobre quais eram as aproximações entre os que justificaram o encaminhamento dos mesmos para o atendimento especializado e quais impactos estes alunos causavam e causam atualmente na escola.

Sabedores do direito à educação para todos, certamente não nos interessa problematizar o que vem a ser deficiência intelectual e o significado de dificuldades de aprendizagem, mas para este estudo é de fundamental importância a análise das manifestações, aproximações e distanciamentos dos fenômenos evidenciados por esses alunos sem desconsiderar suas características frente à diversidade humana. Dessa forma, o que se propõe é problematizar o cumprimento dos direitos plenos à educação a todos os sujeitos, objetivando assim apontar caminhos que contribuam para a superação do que está instituído.

Nessa objetivação, verifica-se que o processo de inclusão educacional vem mascarando uma realidade caótica das escolas: a exclusão de todos aqueles que são conduzidos pelo capital a fracassarem diante do sistema. Os alunos com defíciência intelectual e alunos com dificuldades de aprendizagem, denunciam esse processo explicitamente, pois a queixa escolar estando direcionadas a eles, encortinam as reflexões sobre o sistema como um todo visto que as discussões acerca do potencial de inteligência categoriza estes sujeitos como sendo os únicos fracassados na escola pública.

$\mathrm{Na}$ tentativa de superação das concepções hegemônicas, cabe-nos problematizar os desafios da escola como sendo uma instituição educacional para todos, ao considerar o movimento inclusivo como aquele que, para além do acesso e da matrícula, se pressupõe a participação com qualidade de todos os alunos nas atividades escolares.

Como anunciado, este estudo não tem pretensão de se deter nas reflexões acerca da deficiência intelectual ou dificuldades de aprendizagem, mas procurar analisar as demandas da escola a partir das manifestações do seu público quando esses alunos categorizados, muitas vezes, não correspondendo às expectativas frente às suas produções, causam impactos e permanecem "excluídos" mesmo estando "dentro" da escola.

$\mathrm{Na}$ intenção de declarar a importância fundamental da aprendizagem e das interações sociais para o desenvolvimento humano, em consonância com Omote (1995), é 
fundamental colocar que se acredita que o foco da queixa escolar não se manifesta no sujeito distanciado de sua história, pois se entende que o sucesso escolar e a inclusão social são determinados pelas relações que este indivíduo estabelece com o meio e pelas suas condições concretas de vida. Para tanto, é necessário direcionar a reflexão para o fato de que:

Mais do que olhar para o deficiente e examiná-lo detidamente para se compreender algo acerca da deficiência, é preciso olhar para a coletividade que o identifica como deficiente, encaixando-o em uma categoria de desviante e tratando-o distintamente. Ninguém é deficiente por si só. Alguém é deficiente perante uma audiência e dentro de determinadas circunstâncias. (OMOTE, 1995, p. 47)

Na busca pela compreensão e superação do que está instituído, sabe-se que é preciso resgatar o contexto em que foram estruturados os caminhos pelos quais a educação enveredou junto ao grupo de alunos que não correspondiam aos padrões de normalidade e que foram então encaminhados às salas especiais. Dessa maneira, na busca por elementos que identifiquem aproximações e distanciamentos entre a deficiência intelectual e dificuldades de aprendizagem é preciso o exercício da visão sócio-histórica. Em conformidade com Bock, entende-se que o sujeito é:

[...] um ser constituído no seu movimento; constituído ao longo do tempo, pelas relações sociais, pelas condições sociais e culturais engendradas pela humanidade. Um ser que tem características forjadas pelo tempo, pela sociedade e pelas relações. O homem é visto a partir da idéia de condição humana; o homem é um ser que constrói suas formas de satisfação das necessidades e faz isso com os outros homens. A relação indivíduo/sociedade é vista como uma relação dialética, na qual um constitui o outro. O homem constrói-se ao construir sua realidade [...] (BOCK, 2000, p. 24)

Entendendo o homem nesse movimento, faz-se necessário identificar os mecanismos que invadiram o sistema educacional sustentados pelas marcas do liberalismo que ainda permeiam as escolas, quando enfatizam o discurso da competência sustentado pelo respeito às diferenças e necessidades individuais.

Dessa maneira, é válido destacar que se busca apresentar as reflexões a partir da perspectiva histórica tendo clareza da necessidade da articulação e construção de uma escola articulada com outros espaços que venham atender às necessidades básicas de "aprendizagem" de todos os alunos. Portanto, na continuidade do capítulo, apresenta-se o processo de reestruturação da rede de ensino de Santo André, clarificando o processo de municipalização que se objetivou à democratização do acesso à educação. 


\subsection{A Educação no Município de Santo André: processo de municipalização do ensino e seu percurso histórico.}

Apontando para a descentralização do poder, a Constituição de 88 coloca dispositivos que indicam conferir total autonomia político-administrativa aos municípios ${ }^{4}$, declarando os mesmos como esferas autônomas entre as outras que compõem a federação.

Sabe-se que a ampliação dos direitos se expressa principalmente no que se refere à garantia à escolaridade, conforme declarado no artigo 208 da Constituição, quando indica a obrigatoriedade de:

- extensão do ensino fundamental obrigatório e gratuito para os que a ele não tiveram acesso na idade própria e a progressiva incorporação no ensino médio;

- atendimento em creche e pré - escola de crianças de zero a seis anos de idade; - atendimento especializado aos portadores de deficiência e ao aluno de baixa renda, através de programas suplementares de material didático, transporte, alimentação e assistência à saúde. (BRASIL, 1988, p.35)

$\mathrm{Na}$ continuidade da descrição do percurso a ser implementado, a Constituição Federal (BRASIL, 2010, p.35), através do artigo 211, coloca que "a União, os Estados, o Distrito Federal e os Municípios organizarão em regime de colaboração seus sistemas de ensino, sendo que os municípios atuarão prioritariamente no ensino fundamental e préescolar".

O percurso de descentralização a partir da municipalização do ensino coloca desafios apontando a necessidade de superação dos mesmos, uma vez que é necessária articulação de todos os envolvidos no processo, principalmente no tocante à distribuição dos recursos financeiros. Para o enfrentamento desses desafios, coloca-se a importância de se constituir a Comissão de Educação Municipal, devendo esta ser composta por representantes do Executivo, do Legislativo e da Sociedade Civil através de um representante da Secretária de Educação, representante de professores, diretores de escola e de pais, bem como prefeito ou Dirigente Municipal de Educação, cabendo a estes identificar as prioridades e, a partir de então, estabelecer diretrizes e formas de implementação de propostas que visem solução para as demandas da comunidade local.

Nesse encadeamento, década de 90, dois anos após a Constituição Federal de 1988 declarar o direto à educação à todos, Santo André, buscando transformações na área educacional, dá início ao planejamento e articulações objetivando encontrar caminhos

\footnotetext{
${ }^{4}$ Indica-se que nesse capítulo, o processo educacional será problematizado a partir de uma Política de Estado no âmbito municipal.
} 
possíveis para atender indistintamente os alunos na rede regular de ensino, quando então é promulgada a Lei Orgânica do município.

A administração política nesse período $^{5}$ firma compromisso com a luta pela garantia e manutenção do ensino, sinalizando entender que a educação para todos é o caminho para o desenvolvimento da sociedade andreense. Clarificando o percurso a ser implementado, a lei orgânica, declara no Artigo 247, que:

O Município organizará o sistema municipal de ensino, providenciando o atendimento escolar nas modalidades de:

I- educação infantil

II- educação de jovens e adultos

III- educação especial. (SANTO ANDRÉ, 1990, p.1)

Após dois anos da promulgação da lei orgânica municipal, em 1992, o município passa a contar com 37 unidades escolares quando, na sua maioria, atendia alunos da educação infantil e modalidade de jovens e adultos. O ano de 1992 é marcado pela objetivação da gestão em resgatar o papel da escola municipal enquanto provedora de um ensino para todos, sem distinção de condição ou de classe social, quando a administração municipal, incorpora em todas as suas propostas o tema "Inclusão", sendo este, o conceito responsável pelo início da viabilização de programas em todos os segmentos da atuação da política pública local.

Um recorte desse cenário educacional do município de Santo André será aqui destacado a partir da educação especial para que se possa apresentar o trabalho desenvolvido junto aos alunos matriculados na rede regular de ensino que possuíam diagnóstico de deficiência.

Em conformidade com as reflexões colocadas até este momento, as idéias de anormalidade, carência e de falta de condições para o desenvolvimento pedagógico se justificavam, ou ainda continuam sendo justificadas, no sujeito ou na família. Tal fato é evidenciado por Machado (2007, p. 145) ao afirmar que "essas idéias ganharam vida própria, pois muitas vezes [...] ouvimos que as crianças têm distúrbios de aprendizagem, desnutrição, família muito pobre, como se essas idéias não tivessem sido produzidas historicamente".

Anterior à apresentação das ações desencadeadas pela política pública educacional do município direcionada aos alunos com deficiência, entende-se como

\footnotetext{
${ }^{5}$ Clarifica-se os períodos citados nesta pesquisa e os respectivos partidos governamentais frente a política pública do município de Santo André sendo do ano de 1989 à 1992 - Partido dos Trabalhadores (PT); de 1993 à 1996 - Partido Trabalhista Brasileiro (PTB); de 1997 à 2008 - Partido dos Trabalhadores (PT) e de 2009 à 2012 - Partido Trabalhista Brasileiro ( PTB).
} 
importante recolocar que a Constituição Federal Brasileira de 1988 (BRASIL, 1988, art. 208, p. 96) já declarava que "o atendimento educacional aos portadores de deficiência será preferencialmente na rede regular de ensino" quando, neste momento da história de Santo André, a rede municipal de ensino ainda não oferecia atendimento aos alunos com deficiência.

Em atendimento ao preconizado na Constituição Federal, no ano de 1989, junto ao ensino regular, se dá a criação do Serviço Especial quando a equipe é formada a partir de concurso público contando com a contratação de seis pedagogos com habilitação nas diferentes áreas de deficiência e dois psicólogos. Esses profissionais iniciam o processo de atendimento aos alunos com deficiência que são matriculados nas EMEIs (Escola Municipal de Educação Infantil). Esse serviço da Educação Especial oferecido à população andreense já indicava o início de investimentos de políticas públicas locais para a construção de uma educação inclusiva quando se tinha como diretriz o respeito à diferença, entendendo-se que não se podia desconsiderar a segregação da pessoa com deficiência enquanto resultado de determinações históricas e culturais, cujo rompimento com os paradigmas de exclusão só se daria com as transformações das relações sociais.

Desse modo, o processo de "inclusão" dos alunos com deficiência na rede regular de ensino é iniciado a partir de 1991 conforme instituído e registrado nos artigos 252 e 253 da Lei Orgânica do Município, promulgada em 1990, quando esta declara que:

Art. 252 - É obrigatória a avaliação da criança em creche, pré-escola e ensino fundamental, com a finalidade de se diagnosticar deficiência física e mental.

Art. 253 - O Município assegurará, em sua rede oficial de ensino, educação especial às pessoas portadoras de deficiência e às autistas, por meio de ações educativas com vistas às suas particularidades, com a finalidade de garantir o máximo desenvolvimento de suas potencialidades, bem como sua integração no convívio social. (SANTO ANDRÉ, 1990, p. 2)

Observa-se nesse momento histórico consonância com os princípios de um processo educacional enquanto direito de todos quando, Santo André (2000, p. 17) afirma que este serviço "foi criado, como resultado das conquistas dos deficientes [...] rompendo com a dicotomia entre classe regular e classe especial $[\ldots]$ ”.

Sob esse contexto histórico, os alunos eram transferidos de escolas especiais para as EMEIs (Escolas Municipais de Educação Infantil) dando início a uma perspectiva educacional com foco na inclusão escolar, como estabelecido na Constituição Federal e reafirmado na Declaração de Salamanca. 
Quanto aos dados de matrícula dos alunos com deficiência, encontra-se registrado no documento Perfil do Município da Região Metropolitana de São Paulo, Fundação Sede, 1993, que a rede atendia no ano de 1992 "100 alunos com deficiência”. Número considerável por se tratar do início de um processo educacional inclusivo datado da década de 90 quando a problematização em torno das possibilidades da participação dos alunos com deficiência nas redes regulares de ensino eram timidamente debatidas. Nesse aspecto, a cidade de Santo André, dentre as outras regiões do $\mathrm{ABCD}$, torna-se pioneira.

Há poucos registros sobre o início desse percurso frente à experiência educativa denominada como inclusiva que se deu por apenas três anos, quando então, o serviço oferecido aos alunos com deficiência é interrompido no ano de 1993.

Tal fato é determinado pela gestão do período quando esta opta pelo retorno do trabalho educacional segregativo. A Revista Estação Gente, referindo-se a interrupção do atendimento educacional inclusivo, afirma que:

No ano de 1993, porém, o mesmo é interrompido por quatro anos, pois a então administração tinha outra concepção, isto é, era melhor para o deficiente sua freqüência às classes especiais, acredita-se na qualidade do atendimento segregado. O que se evidencia naquele momento é uma grande defasagem em relação a todos os movimentos que vinham trabalhando em defesa dos deficientes. (SANTO ANDRÉ, 1997. p. 17)

Sendo esse serviço interrompido, os alunos com deficiência voltam às salas especiais. É necessário clarificar que as "salas especiais" são projetadas dentro de uma escola comum, no entanto são formadas por um coletivo de alunos com diagnóstico de deficiência. Sobre esse formato de atendimento, Carneiro (1997, p. 127) afirma que esses alunos, "anteriormente segregados em instituição de ensino especial, continuam segregados, só que agora dentro de uma escola regular, dita para todos".

Entende-se que nesta perspectiva da segregação/integração, a hierarquização construída entre os alunos mais capazes e os menos capacitados é estabelecida também dentro das classes comuns, mas quando se trata de implementar a sala especial dentro da escola comum, pauta-se exclusivamente no modelo de hierarquia social, quando os mais desfavorecidos tem que ser mantidos afastados do todo. Nessa direção, Crochík (1997, p. 13) indica que "como se trata de pensar a diferenciação como forma de preconceito na escola pública, deve-se apontar para os elementos objetivos e subjetivos que permitem a segregação".

Do ponto de vista pedagógico e social, o que se propõe entre os anos de 1993 a 1996 pela gestão pública, pode ser declarado como sendo um retrocesso, pois se retorna aos 
padrões da "integração educacional" quando os alunos com deficiência eram aglutinados na mesma sala de aula. Estes passam a ser matriculados na classe especial e segundo Crochínk (1997, p. 14), "quando falamos de classes especiais, estamos positivando a negação, ou seja, afirmando aquele que é negado para que ele seja mais uma vez negado”.

A integração educacional materializa-se quando apenas em alguns momentos os alunos com deficiência podem participar das ações desencadeadas junto às salas comuns. Essa participação acontece quando thes é concedido a oportunidade de interagir, desde que os mesmos apresentem condições para se fazerem particípes, como propõe pensar Carneiro, afirmando que:

[...] discutir a integração desses alunos no ensino regular envolve questões tais como as diferentes concepções de deficiência e com elas todo o problema de avaliação, diagnóstico e prognóstico daqueles indivíduos que não correspondem à expectativa de normalidade colocada pelos padrões sociais. (CARNEIRO, 1997, p. 128)

Este modelo de educação especial integrativa se deu até que a nova administração, a partir de 1997, assumi novamente o formato de trabalho iniciado em 1990. Sendo assim, passa a atender a legislação ao reiniciar o atendimento em conformidade com o que estava proposto em diversas leis já citadas, como na Constituição Federal de 1988, na Declaração de Salamanca de 1994.

Sob nova administração, em 1997, o município retoma o processo educacional inclusivo, pautando-se no princípio do direito a educação para todos, independente do diagnóstico ou de qualquer manifestação apresentada pelos sujeitos, afinal, entendia-se que a escola matricula alunos e não suas características. Na perspectiva da garantia ao direito à educação, a política educacional do município passa a assumir enquanto objetivo:

- a democratização do acesso e garantia da permanência dos alunos nas escolas;

- a gestão democrática do sistema educacional;

- a qualidade de ensino, concebida seguindo os princípios da educação Inclusiva.

(SANTO ANDRÉ, 1997, p.9)

Além da retomada do processo educacional inclusivo, em 1998, participando do debate impetrado pelo governo estadual e referendado pelo FUNDEF - Fundo do Desenvolvimento Educacional Fundamental, Santo André opta pela implantação dos quatro primeiros anos do ensino fundamental quando, através da Lei Municipal 14.146 de 27 de Abril de 1998 (dando continuidade a reorganização e ampliação dos serviços educacionais), a rede municipal passa a atender não só os alunos da educação infantil e a modalidade de jovens e adultos como também, incorpora ao seu quadro, a modalidade do ensino fundamental I. 
Iniciando o processo de municipalização, os alunos são matriculados nas EMEIFs- Escolas Municipais de Educação Infantil e Fundamental e todos os que possuíam diagnóstico de deficiência passaram a freqüentar a sala de aula comum. Com esse movimento, retoma-se o que se concebia por processo educacional inclusivo.

Nessa concepção, busca-se recolocar o humano no centro do processo educacional quando então a Educação Especial e seus sujeitos, professores especialistas nas áreas de deficiência e todos os alunos atendidos por estes, são incorporados legitimamente ao processo educacional.

Dentro das categorias colocadas, sabe-se que a polêmica permeia as discussões acerca do potencial de inteligência dos alunos com deficiência, o que acarreta manifestações de preconceito e, portanto, a partir do ano de 1997, timidamente os pais reiniciam a busca pelo direito à participação dos seus filhos nessa escola regular, sendo que um pequeno número de alunos com deficiência inicia sua trajetória educacional na rede de ensino.

Em decorrência a esse movimento educacional inclusivo, entre os anos de 1997 a 1998, Santo André declara atender 98 alunos com deficiência, quando entre os anos de 1998 a 1999, há uma crescente demanda de matrículas de alunos com deficiência na rede, o que direciona a política pública local a criar mecanismos que viessem a potencializar e garantir a estrutura do serviço oferecido à população. Santo André (2000, p. 50) registra os dados de evolução de matrículas na Revista Estação Gente - Educação Inclusiva, indicando que até o ano de 1999 atendeu "127 alunos com deficiência clínica e 158 sem diagnóstico", estando estes últimos em observação, portanto totalizando 285 alunos sendo acompanhados pela equipe.

Diante do crescente índice de matrículas, os representantes da política pública local, frente ao projeto educacional inclusivo, entendiam que as demandas dos alunos com deficiência indicavam situações no cotidiano escolar que mereciam atenção e compreensão, pois, como declara Tanamachi, é preciso:

Tomar a escola a partir de concepções progressistas de Educação que, de modo crítico, buscam entender o homem concreto (produto das relações sociais que se estabelecem no nível da consciência mais ampla e capaz de produzir e transformar a sua própria história), apontando para a necessidade de uma Educação justa, capaz de atender aos seus interesses. (TANAMACHI, 2000, p. 81)

Dessa forma, quando as avaliações e discussões alargam o entendimento sobre o serviço oferecido às famílias e às escolas, identifica-se a necessidade de reestruturação do 
sistema quando então é criado o CADE (Centro de Atenção ao Desenvolvimento Educacional).

Nesse encaminhamento, para esta pesquisa, é importante analisar o percurso histórico, suas manifestações e concepções, bem como as ações desencadeadas por esta agência educacional, que se instituiu a partir do ano de 2000 no município de Santo André, quando em parceria com as escolas, propõe-se a atender as demandas advindas das queixas de professores que em suas salas enfrentam desafios para lidar com as manifestações dos alunos com deficiência ou com Transtorno Global do Desenvolvimento.

Embora os profissionais do CADE tenham como demanda acompanhar o processo de desenvolvimento dos alunos com deficiência, busca-se compreender esta agência da política pública educacional local e sua relação com os profissionais da educação pautada no eixo central da ação da escola como sendo o "desenvolvimento humano" independente de suas características. Nesse alinhamento reflexivo, recorre-se a Angelucci (2012) ao declarar que "trata-se de um projeto de Educação que pretende recolocar o humano no centro do processo, o que supõe, necessariamente, implicar-se com outro projeto de sociedade”.

\subsection{CADE - Centro de Atenção do Desenvolvimento Educacional: sua trajetória.}

Como já anunciado, o CADE - Centro de Atenção ao Desenvolvimento Educacional é implantado em 1999, quando o aumento da demanda de matrículas de alunos com deficiência cria novas necessidades junto à Secretaria de Educação.

Estando vinculado à Gerência da Educação Especial, esse equipamento, em sua formação inicial, é instalado no espaço físico de uma creche desativada (ainda sem acessibilidade arquitetônica), quando a equipe de profissionais é ampliada passando a ser composta por dez professores (seis deles com habilitação em áreas de deficiência e quatro formados em Pedagogia) e cinco profissionais da área clínica e terapêutica que em parceria, passam a atender 62 unidades.

Em busca de construir uma proposta educacional inclusiva e preservar a estrutura dessa agência (para que não fosse descartada por concepções de gestão pública), no ano de 2000, a Secretaria de Educação e Formação Profissional transformou o CADE em uma Unidade Administrativa em conformidade com a Lei Orgânica No 8144 de 22 de Dezembro de 2000, declarado por Santo André (2000, p. 1), indicando que "cria a unidade administrativa 
denominada Centro de Atenção ao Desenvolvimento Educacional - CADE - Direitos Humanos".

O CADE, enquanto agência do governo municipal é um dispositivo importante a ser problematizado neste estudo pelo fato de que as ações desencadeadas pelos seus profissionais ocorrem em parceria com os professores que têm em sua sala alunos com deficiência. A parceria entre os profissionais das escolas e do CADE se estabelece a partir da necessidade de aprofundamento das reflexões acerca da função social de todos os envolvidos com o aluno com deficiência e da relação deste com todos os outros. Sabe-se que, pelo diagnóstico e pelo prognóstico destes alunos, os profissionais da escola multiplicam as queixas escolares sobre os que não conseguem corresponder aos padrões de normalidade impostos pela escola. Sobre esse aspecto, Carneiro afirma que:

[...] há muitos preconceitos acerca das capacidades intelectuais das crianças provenientes de classes populares. Se além de pobres (ou muitas vezes por ser pobres), apresentarem alguma deficiência, a discriminação é ainda maior: A exclusão pelo fracasso escolar é um ônus; somada à estigmatização da deficiência [...] é um duplo ônus [...]. (CARNEIRO, 1997, p. 131)

Portanto, com a intenção de problematizar as relações estabelecidas entre todos os envolvidos nesse processo, cabe colocar o que é determinado ao profissional do CADE a partir da lei Orgânica, quando esta determina que:

Art. $2^{\circ}$ - São competências do CADE: auxiliar o professor no diagnóstico das dificuldades relativas ao ensino e aprendizagem apresentadas, prioritariamente, aos alunos com necessidades educativas especiais; orientar os professores do ensino regular de educação infantil, ensino fundamental, educação de jovens e adultos e os monitores de creches que interagem com alunos com necessidades especiais; propor caminhos para a superação das dificuldades encontradas, de ordem pedagógica ou clínica, nas instâncias adequadas, oferecer atendimento clínico em parceria com a Secretaria de Saúde; estender o atendimento especializado aos demais usuários e formar os funcionários da unidade. (SANTO ANDRÉ, 2000, p. 1).

Neste momento da história do CADE, a parceria da saúde e educação ocorre num mesmo espaço físico.

Como já colocado, no prédio designado para atender as demandas oriundas das necessidades apresentadas pelos alunos com deficiência, atuavam equipe clínica com especialização nas áreas da fisioterapia, fonoaudiologia e psicologia, professores de Educação Especial e Pedagogos.

Esta equipe propõe construir uma rede de apoio para, juntos (equipe de professores e terapeutas), atuarem viabilizando suporte não só aos professores através das adaptações técnicas de materiais pedagógicos, bem como otimizando ações que atendessem às 
necessidades mapeadas junto aos alunos com deficiência, com o objetivo de potencializar seus recursos.

Dessa forma, a equipe realiza um trabalho itinerante, observando e avaliando os alunos nas escolas e também os atendendo no prédio do CADE de acordo com as especialidades e as necessidades apresentadas pelos alunos com deficiência.

Nesse formato, os profissionais da saúde e da educação, permaneceram juntos atendendo aos alunos da rede até o início de 2003, quando uma nova reorganização da equipe é colocada em prática.

Frente a nova organização da equipe, os profisssionais da Educação Especial e os Pedagogos permanecem atuando de acordo com o designado para suas funções a partir do mesmo espaço físico (inclusive contando a partir de então com uma significativa ampliação do quadro de professores) enquanto que os profissionais com especialização nas áreas clínica e terapêutica são realocados e retornam para exercerem suas funções junto à Secretaria da Saúde, mais especificamente no CREM (Centro de Reabilitação Municipal), fundado no ano de 2000. Sobre esse movimento, Carla Bertual declara que:

[...] a construção do SUS é a constituição de uma rede de serviços hierarquizados pelo grau de complexidade das ações práticas, integrados através da referência e contra-referência, eficazes e distribuídos especialmente de forma a assegurar o amplo acesso dos usuários. A orientação de sua atividade, apolítica de saúde deve ser democraticamente escolhida sendo assegurada a ampla participação popular. (BERTUAL, 1997, p. 162)

Nesse reordenamento das ações, a Secretaria de Saúde é responsabilizada e convidada a repensar o processo de atendimento aos munícipes, pois entende-se que todos têm direito ao atendimento, independente de estarem ou não matriculados na rede municipal de ensino, legitimando assim o critério do SUS (Sistema Único de Saúde), que é a universalização do atendimento. Além de esta reorganização colocar o atendimento clínico e terapêutico no foco de sua área, a saúde, objetiva-se também alargar a compreensão sobre a parceira estabelecida com a educação, pois, naquele momento, predominava o atendimento pautado no modelo clínico. Maluf (1994, p.157) propõe pensar no equívoco deste ao afirmar se "tratar de modo centrado no indivíduo problemas cuja origem é multideterminada, e que são socialmente influenciados mesmo nos casos em que sua base é de natureza orgânica".

Dada à necessidade, coloca-se que essas mudanças se deram juntamente com o avançar das idéias da Política Pública de Educação local, quando os conceitos que permeavam o processo educativo eram problematizados a partir das formações que envolviam análise sobre o papel da saúde, a função da educação e o público alvo da Educação Especial. 
Quanto à Educação Inclusiva, buscava-se a compreensão do como construir este processo a partir da interlocução dos profissionais da saúde e da educação, estabelecendo parceria de modo que uma área não sobrepusesse a outra, ambas compreendendo o propósito educativo de todos os envolvidos neste processo histórico.

Com o distanciamento da equipe clínica e terapêutica, a Educação entende que a parceria deveria continuar. No entanto, cada profissional atuando a partir da Secretaria a que se vinculava, continuaria compondo o quadro de profissionais que em "rede de apoio" atenderiam as necessidades apresentadas pelos alunos com deficiência.

Ao atender às demandas num prédio antigo, sem acessibilidade arquitetônica, as formações e discussões sobre a problemática em questão desencadeiam novas necessidades que são justificadas a partir dos mapeamentos na rede pelos profissionais do CADE, ao fazerem o levantamento das reais condições apresentadas pelos professores. As ações da equipe vão se reestruturando a partir das queixas sobre o desenvolvimento dos alunos com deficiência, sendo válido destacar que, neste movimento, a assessoria passa a oferecer escuta aos professores que relatam seus dramas sobre o desenvolvimento dos alunos com dificuldades de aprendizagem. Sobre esse aspecto, Souza propõe pensar que:

Os protagonistas da escola em condições sociais, culturais e materiais específicas realizam a existência cotidiana da escola singular e ao fazê-lo refletem todos os elementos formais e não formais do sistema relacionados com os de seu contexto social. (SOUZA, 2000, p. 127)

Entre os anos de 2001 e 2002, com o alargamento das concepções inerentes ao processo, a equipe do CADE se aproximava cada vez mais das angústias dos professores frente ao rendimento escolar dos alunos com deficiência, mas também, grandes angústias são motivadas pelo baixo desempenho dos alunos caracterizados como aqueles que apresentavam dificuldades de aprendizagem. Tais manifestações sinalizam a importância de ações formativas e de participação da assessoria nos planejamentos pedagógicos, pois se percebe que as queixas se direcionam exclusivamente aos sujeitos. Sobre esse aspecto, Carneiro (1997, p. 142) afirma que "não se trata evidentemente de negar as limitações, sejam elas físicas, sensoriais, neurológicas ou mentais, mas trata-se de lidar com o indivíduo que se relaciona e expressa o movimento da sociedade em que vive".

Vale colocar que, nesse momento da história da educação no município, principalmente quando o fenômeno do fracasso escolar permeia o processo educativo, a equipe do CADE se torna alvo de muitas cobranças, visto que ainda com um número reduzido 
de profissionais não consegue se fazer presente, periodicamente, em todas as unidades escolares.

Analisando as situações mapeadas no município, a equipe identifica a importância, não só de um novo espaço, mas também da ampliação do seu quadro de funcionários, pois percorrendo as escolas e entrando em contato com as demandas dos alunos e seus professores, surge a urgente necessidade de problematização sobre o percurso de todos os agentes da escola quando estes manifestam estranheza frente às manifestações dos alunos, suas necessidades e possibilidades educativas.

Nesse movimento, em 2002, acontece o I Seminário de Gestão de Educação Inclusiva no Museu de Arte de Santo André, quando se apresenta o mapeamento realizado com as famílias dos alunos com deficiência, o diagnóstico de acessibilidade pedagógica das unidades escolares e levantamentos realizados com as instituições parceiras, além do desencadeamento das reflexões sobre os desafios e dificuldades encontrados pelos alunos e seus professores frente ao processo de educação inclusiva. Neste seminário, reapresentam-se as diretrizes que norteiam a política de Educação Inclusiva sendo elas: acesso, permanência, democratização da gestão e construção da qualidade social da Educação. No final desse mesmo ano, 65 professores da rede municipal de ensino se inscrevem para processo seletivo para compor a equipe do CADE, quando no início de 2003 são selecionados 11 destes, que passam a fazer parte da equipe (os professores neste momento da história ainda não assumiam função gratificada de professor assessor) iniciando assim minha atuação a partir de estudos sobre a deficiência física, deficiência mental, deficiência auditiva e surdez, deficiência visual e cegueira, múltipla deficiência e Transtornos Globais do Desenvolvimento. Ampliou-se o serviço do CADE, sendo neste momento composto por 23 profissionais, todos da Educação.

Nesse mesmo ano, o CADE também passa a dispor de uma coordenadora, fato que viabiliza à Gerência da Educação Inclusiva, maior disponibilidade para articulações junto à política pública local.

No ano de 2003, na Bolívia, Chefes de Estado dos Países Ibero-americanos, assinam documento, definindo esse, como um ano estratégico para o fortalecimento de políticas públicas de inclusão das pessoas com deficiência e, para Santo André, esse também passa a ser um ano decisivo e marcante na trajetória da Educação Inclusiva. Para além das articulações de política pública local, Santo André, representado pela Gerência do CADE, busca compartilhar os conhecimentos participando do Congresso de Pedagogia em Cuba, apresentando o Projeto de Educação Inclusiva. Segundo registros de Santo André (2003, p. 5), 
"este Congresso possibilitou uma importante troca de experiência e reflexão para os diferentes modelos de atuação e as diferentes realidades apresentadas pelos países participantes”.

Naquele mesmo ano, no mês de novembro, dando continuidade as ações direcionadas à qualificação de todo o processo educacional inclusivo, a Secretaria de Educação, a partir da Gerência da Educação Inclusiva, lança o livro Poéticas das Diferenças (2003), um dos materiais construídos pelos profissionais da educação que deveria ser acessibilizado a todos os envolvidos no processo, pois estratégica e legitimamente fora objetivado para ser um instrumento de formação a partir do diálogo estabelecido com os mesmos frente às suas atividades educativas. A elaboração desse livro foi projetada entendendo que não bastava identificar as patologias, deficiências e limitações dos alunos, pois diante de tais características era necessário reconhecer as necessidades, possibilidades, potencialidades e recursos dos alunos frente ao processo de construção do conhecimento, e não suas incapacidades.

Ainda em 2003, no dia 3 de Dezembro, Dia Internacional pela Luta pelos Direitos da Pessoa com Deficiência, na câmara dos vereadores do município de Santo André, foi realizado o lançamento do Guia de Recursos para Pessoas Portadoras de Deficiência (2003). Esse material fora construído com o objetivo de facilitar o acesso às informações (principalmente para as famílias dos alunos com deficiência) sobre os diversos serviços existentes no próprio município que pudessem atender gratuitamente a população nas áreas de esporte, saúde, cultura, transporte, lazer, assistência jurídica e social, defesa dos direitos e profissionalização.

Com o avançar das articulações e reflexões sobre todo o processo, é importante colocar que, entre os anos de 2003 a 2006, cada professor passa a ser responsável por uma determinada área de deficiência, portanto muitas vezes uma mesma unidade recebia orientações de dois ou mais profissionais, dependendo da quantidade e especificidade de cada aluno matriculado na escola. $\mathrm{Na}$ medida em que as discussões avançam e a equipe do CADE mapeia em movimento as demandas da rede e as suas próprias, cada profissional passa a atender às escolas, problematizando todas as áreas de deficiências, pois se entendia que neste formato, pensando o aluno e não sua deficiência, a equipe de professores contribuiria muito mais, podendo articular o processo como um todo e não só objetivando especializar-se numa determinada área de deficiência. Amplia-se a compreensão de que é preciso pensar o sujeito e sua história e não apenas sua deficiência quando nesse momento, a equipe do CADE entende que sua atuação exigia pensamento crítico que analisasse a totalidade do processo, pois como declara Meira (2000, p. 60), "a Educação, enquanto um processo ao mesmo tempo social e 
individual, genérico e singular, é uma das condições fundamentais para que o homem se constitua de fato como ser humano, humanizado e humanizador".

Nesse contexto, os profissionais são designados para estabelecerem parcerias com as escolas onde o aspecto formativo direcionado aos professores dos alunos com deficiência seria o centro do trabalho da equipe do CADE. O professor seria o foco deste atendimento, pois, nessa concepção, entendia-se que os alunos seriam beneficiados na medida em que seus professores tivessem acesso à formações que objetivassem a transformação da sua ação frente à "todos os alunos", pois se entendia que:

[...] a existência de mecanismos institucionais e de ações cristalizadas produzem na criança e no professor a impossibilidade de pensar a sua própria condição de submissão e de exclusão no processo educacional. A intervenção vem no sentido de possibilitar o pensar com a criança e o professor essa relação esteriotipada e produtora de repetência, da repetição de práticas que estigmatizam, excluem, oprimem e rotulam. (SOUZA, 2000, p. 127).

Pensar a vida cotidiana da escola conduziu a equipe do CADE a entrar em contato com professores, equipe técnica das escolas (merendeiras, porteiros, secretárias, pessoal da limpeza e outros), diretores, assistentes pedagógicos, coordenadores, pais e profissionais das áreas clínica e terapêutica. Nas reflexões sobre o processo, manifestações equivocadas se evidenciam, pois se deslocam do centro do debate, à função social destes profissionais, destinando as discussões à busca da culpa pelo baixo desempenho dos alunos.

É válido recolocar que, durante todo o percurso de suas ações, a equipe do CADE, se depara com as queixas dos professores frente aos alunos com deficiência sendo que estas queixas se acentuavam e se agravavam quando os mesmos professores se reportavam aos relatos sobre os alunos com dificuldades de aprendizagem. Entende-se que nesse movimento, o baixo rendimento escolar nos alunos com deficiência era justificado pelo seu diagnóstico, enquanto que os alunos com dificuldades e sem diagnóstico eram os que mais causavam inquietações aos professores. Sobre esta categoria de alunos e seus professores, Patto afirma que:

Em termos escolares, são freqüentes as menções a uma aprendizagem lenta e pobre, à apatia e ao desinteresse em sala de aula, às dificuldades de abstração e de verbalização, ao desajustamento diante das regras e exigências disciplinares da escola, aos altos índices de reprovação escolar, além das já tradicionais referências aos problemas de nutrição e saúde e de suas repercussões sobre a aprendizagem e o rendimento escolares. [...] Nesta linha de raciocínio, os educadores vão ainda mais longe, atribuindo ao baixo nível de escolaridade a responsabilidade pela incapacidade pessoal e profissional destes indivíduos, materializada em sua incapacidade de ascensão social. (PATTO, 1997, p. 262-263). 
Diante das necessidades mapeadas junto à rede de ensino, os professores do CADE, entendendo a necessidade de refletir sobre sua atuação, passam a participar de formações baseadas no desenvolvimento humano, no processo pedagógico e nas diferentes áreas de deficiências.

No ano de 2004, ampliam-se as discussões sobre os direitos da pessoa com deficiência. Santo André participa das discussões desencadeadas pelo FOPEI - Fórum Permanente de Educação Inclusiva -, cujo tema "Políticas Públicas para a Inclusão Social das Pessoas com Deficiência" fundamenta o objetivo do município em ampliar suas ações direcionadas a este público. Neste mesmo ano é criado o Centro de Formação de Professores.

Mesmo com o constante investimento da política pública local e a crescente articulação junto às ações objetivadas para atender as demandas advindas das necessidades de todos os envolvidos no processo (professores e alunos), inicialmente, a relação profissional entre os professores assessores do CADE e os profissionais da rede se dava com certa formalidade e fragilidade quando inclusive manifestações de preconceito e de negação eram materializadas pelo discurso ou pelas ações de professores e de suas equipes diretivas e técnicas. Descrédito e ceticismo eram posicionamentos comuns entre os profissionais da educação e das famílias diante de todo o processo educacional inclusivo.

Entrar em contato com as manifestações de negação dos professores acerca das necessidades dos alunos com deficiência era uma das demandas da equipe de professores assessores que, no exercício de escuta atenciosa e formativa, buscava caminhos que conduzissem os sujeitos da escola à possibilidade de reelaboração de seus conceitos e concepções frente ao preconceito e às estranhezas que apresentavam e exercitavam. Portanto, a Secretaria de Educação, representada pela Gerência da Educação Inclusiva, passa a compreender a importância da ampliação dos canais de formação e informação direcionada aos professores da rede.

$\mathrm{Na}$ busca por um ensino de qualidade, a equipe de professores assessores do CADE, passa a desempenhar papel decisivo na construção da mudança de atitude dos profissionais da educação frente aos alunos com deficiência. Ainda nesse mesmo período, em horário de trabalho, todos os professores dos alunos com deficiência são contemplados com formações realizadas pela equipe. Sobre esse processo, Santo André (2004, p.2) declara que "cerca de 500 professores da rede municipal que atendem alunos com deficiência estão recebendo formação sobre a Educação Inclusiva". Durante todo o ano letivo, encontros formativos acontecem nas escolas e no Centro de Formação não só com os profissionais da educação como também com os pais dos alunos com deficiência. Processo que começa dar 
sustentação às necessidades a partir da interlocução que se construía empírica e teoricamente junto às demandas dos alunos e de todos os envolvidos, pois se alarga a compreensão acerca da importância do conhecimento como instrumento de compreensão da realidade e elaboração para a transformação da mesma.

Em 2005, acontece a I Conferência Municipal de Defesa dos Direitos das Pessoas com Deficiência a qual contou com a participação da sociedade civil, representantes da administração municipal e equipe do CADE, que debateram o tema acessibilidade. Agregando ao tema debatido, nesse mesmo ano, foi inaugurado o espaço físico designado para ser sede do CADE, passando a receber e atender seus profissionais e todas as demandas da educação inclusiva em prédio concebido arquitetonicamente de maneira a focar os princípios de sustentabilidade e acessibilidade.

Ainda no ano de 2005, é criado o NUPEI - Núcleo de Práticas em Educação Inclusiva - voltado para o atendimento dos alunos com Transtorno Global do Desenvolvimento. Este serviço, oferecido no contra turno da aula regular, compôs também com o atendimento voltado aos alunos com surdez e deficiência auditiva que eram atendidos no horário oposto de suas atividades escolares. Tal proposta tinha como objetivo atender as demandas específicas desses alunos de modo a potencializarem seus recursos para que, em sala de aula regular, pudessem participar proativamente.

$\mathrm{Na}$ continuidade de implementação dos projetos voltados ao atendimento das necessidades dos alunos acompanhados pela equipe do CADE, a política pública local, inaugura o CAPSI- Centro de Apoio Psicossocial Infantil -, sendo este um serviço que em ação conjunta com a educação, atenderia alunos com sofrimento mental.

Os momentos de encontros e reflexões com famílias, professores, equipes técnica e diretiva de cada unidade escolar sobre o aumento da demanda e das necessidades mapeadas junto às pessoas a respeito dos processos pedagógicos, conduziram a implantação da política pública local a partir de articulações que otimizassem parcerias com instituições que pudessem compor no atendimento aos alunos com deficiência. Tais atendimentos aconteciam no CREM - Centro de Reabilitação Municipal -, que, de acordo com o que já fora colocado sobre a universalização do sistema de saúde, atendia toda população do município, criando assim um déficit no atendimento.

Portanto, em decorrência do mapeamento realizado, ainda no ano de 2005, parcerias foram estabelecidas com: o Centro de Aconselhamento Genético / USP, DERDIC Divisão de Educação e Reabilitação dos Distúrbios da Comunicação / PUC, Fundação Dorina 
Nowil, Instituto Therapon, Lar Escola São Francisco/ UNIFESP e NANI - Núcleo de Atendimento Neuropsicológico Infantil Interdisciplinar.

Esse último veio a compor com o processo de diagnóstico e formação sobre o desenvolvimento dos alunos com dificuldades de aprendizagem uma vez que, como já citado, os professores sinalizavam angústias e fragilidades frente ao fracasso escolar apresentado pelos alunos que não tinham deficiência, mas que não correspondiam às expectativas no desenvolvimento acadêmico. É importante destacar que no processo de diagnóstico dos alunos encaminhados, reuniam-se a família, os professores do CADE e a equipe do NANI para, em rede de apoio, problematizarem as necessidades e potencialidades dos alunos, com a finalidade de devolutiva às professoras sobre o levantamento realizado junto ao seu aluno.

Com o avançar das idéias e das ações encaminhadas que atendessem qualitativamente o percurso educativo dos alunos com deficiência, após três anos de atuação como professores itinerantes, os professores do CADE, são beneficiados assumindo funções gratificadas, após a Câmara Municipal aprovar e promulgar a lei $n^{\circ}$ 8887, de 10 de Novembro de 2006 afirmando, a partir do Art. 8', que "ficam criadas no quadro do Magistério Municipal, 30 (trinta) funções gratificadas de Professor Assessor de Educação Inclusiva". (SANTO ANDRÉ, 2006, p. 1)

O quadro de profissionais assume, a partir de então, nova identidade quando os PAEIs (Professores Assessores de Educação Inclusiva) são apresentados pela Secretaria de Educação às equipes das escolas e incorporados a elas, assumindo um lugar legitimado junto às mesmas, pois, em parceria efetiva passam a tomar decisões, realizando os encaminhamentos sobre as demandas necessárias de maneira articulada com todos os sujeitos da escola. Nesse movimento, a rede municipal de Santo André é informada que a equipe diretiva de cada unidade escolar passaria a ser composta pelo diretor e seu vice, assistente pedagógico e professor assessor de educação inclusiva. Uma grande conquista, visto que a assessoria passa a desempenhar as ações compartilhadas e legitimadas com o coletivo de cada unidade escolar não precisando mais se submeter a conquistar um espaço de concessão para poder participar frente as demandas advindas das necessidades educacionais especiais dos alunos com deficiência, seus professores e famílias.

No ano de 2007, o Parapan-Americano reuniu no Rio de Janeiro 1.300 atletas de diversos países das Américas quando todos buscam classificação para participarem da Paraolimpíada de Pequim. Em Santo André, no mesmo período, a Secretaria de Educação realiza investimento nas formações direcionadas às assistentes pedagógicas de cada unidade escolar uma vez que se entendia que tais assistentes deveriam participar da tomada de decisão 
e de encaminhamento frente às demandas dos alunos com deficiência. Dessa forma, tais assistentes recebem formação durante aquele ano letivo a partir das diferentes áreas de deficiência, quando o foco dos estudos e das discussões são direcionados de forma a instrumentalizar os professores dos alunos com deficiência. Entendia-se que oportunizar cursos especializados nas diferentes áreas da deficiência fazia parte da demanda da equipe do CADE no entanto, ao longo de sua trajetória, os desafios encontrados nas escolas remetiam a debates bastante complexos, exigindo uma visão multidisciplinar sobre as especificidades das deficiências, mas, sobretudo, para o exercício pedagógico, pois os relatos sobre as dificuldades de aprendizagem a cada ano se intensificavam.

A equipe de professoras assessoras passa então a problematizar junto às assistentes pedagógicas o desenvolvimento dos alunos com dificuldades de aprendizagem antes que os mesmos fossem encaminhados para diagnósticos. Sobre tais aspectos, Moysés considera que, aos alunos considerados "doentes", são solicitados diagnósticos como se estes estivessem impregnados de problemas, quando na verdade se percebia que:

\begin{abstract}
São crianças que não passam numa prova de ritmo e sabem fazer uma batucada. Que não tem equilíbrio e coordenação motora e andam em muros e árvores. Que não tem discriminação auditiva e reconhecem canto de pássaros. Crianças que não sabem dizer os meses do ano, mas sabem época de plantar e colher. Não conseguem aprender os rudimentos da aritmética e, na vida, fazem compras, sabem lidar com dinheiro, são vendedoras na feira. Não têm memória e discriminação visual, mas reconhecem uma árvore pelas suas folhas. Não tem coordenação motora com o lápis, mas constroem pipas. Não tem criatividade e constroem seus brinquedos do nada. Crianças que não aprendem nada, mas aprendem e assimilam o conceito básico que a escola lhes transmitem, o mito da ascensão social, da igualdade de oportunidades e depois assumem toda a responsabilidade pelo seu fracasso escolar. (MOYSÉS, 2001, p. 42)
\end{abstract}

Durante esses encaminhamentos, na tentativa de compreender os fatos, suas múltiplas determinações e as possibilidades de superação, os professores assessores solicitam formações voltadas à problematização da pedagogia e às possibilidades de contribuição da ação educativa frente às demandas do cotidiano escolar, pois era preciso, em conformidade com Moysés (2001, p. 20), “compreender as necessidades que determinam a participação do indivíduo no processo de construção do saber e as finalidades que o norteiam contribui para a ampliação do conhecimento deste processo".

No ano de 2008, o município investe na ampliação das Salas de Recursos Multifuncionais (extinto NUPEI- Núcleo de Práticas Educativas Inclusivas) e na formação de professores assessores que poderiam atuar nestas salas quando se tem como objetivo que estes profissionais, pudessem ser multiplicadores do processo de formação sobre o AEE - 
Atendimento Educacional Especializado. Dessa forma, seis professores assessores são selecionados para participarem da formação oferecida pelo MEC.

Frente ao crescente número de matrículas de alunos com deficiência, ainda em 2008, dando continuidade às discussões e articulações que qualificassem o processo, a equipe do CADE, juntamente com a Secretaria de Educação, passa a analisar a contratação do ASI (agente social de inclusão) que, segundo orientações do MEC, poderia atuar na perspectiva de contribuir com as demandas advindas dos alunos com deficiência. Conforme as orientações da Nota Técnica (BRASIL, 2010),

Dentre os serviços da educação especial que os sistemas de ensino devem prover estão os profissionais de apoio, tais como aqueles necessários para promoção da acessibilidade e para atendimento a necessidades específicas dos estudantes no âmbito da acessibilidade às comunicações e da atenção aos cuidados pessoais de alimentação, higiene e locomoção. (BRASIL, 2010, p. 1)

Na busca por orientar a organização e oferta desses serviços, a Nota Técnica clarifica a função desse profissional de apoio colocando que devem cumprir com sua demanda de trabalho considerando os seguintes aspectos:

- Os profissionais de apoio às atividades de locomoção, higiene, alimentação, prestam auxílio individualizado aos estudantes que não realizam essas atividades com independência. Esse apoio ocorre conforme as especificidades apresentadas pelo estudante, relacionadas à sua condição de funcionalidade e não à condição de deficiência.

- A demanda de um profissional de apoio se justifica quando a necessidade específica do estudante público alvo da educação especial não for atendida no contexto geral dos cuidados disponibilizados aos demais estudantes.

- Em caso de educando que requer um profissional "acompanhante" em razão de histórico segregado, cabe à escola favorecer o desenvolvimento dos processos pessoais e sociais para a autonomia, avaliando juntamente com a família a possibilidade gradativa de retirar esse profissional.

- Não é atribuição do profissional de apoio desenvolver atividades educacionais diferenciadas, ao aluno público alvo da educação especial, e nem responsabilizar-se pelo ensino deste aluno.

- O profissional de apoio deve atuar de forma articulada com os professores do aluno público alvo da educação especial, da sala de aula comum, da sala de recursos multifuncionais, entre outros profissionais no contexto da escola.

- Os demais profissionais de apoio que atuam no âmbito geral da escola, como auxiliar na educação infantil, nas atividades de pátio, na segurança, na alimentação, entre outras atividades, devem ser orientados quanto à observação para colaborar com relação no atendimento às necessidades educacionais específicas dos estudantes. (BRASIL, 2010, p.2)

Inicialmente, esse profissional, ao ser contratado, seria orientado a partir de formações a estabelecer parceria com o professor, auxiliando-o nos momentos em que os 
alunos com deficiência apresentassem necessidade de apoio para se alimentar, se posicionar, usar o banheiro, etc. Fica clarificado que somente quando os alunos manifestassem necessidades específicas, a partir de sua deficiência, esse profissional, desempenharia sua função colaborando e oferecendo apoio ao professor e ao aluno.

A formação daquele profissional se daria no âmbito técnico, no entanto, os mesmos participariam do planejamento colaborando com as reflexões, porém não seriam os responsáveis pelo processo pedagógico, visto não serem formados em pedagogia. Entendia-se a importância de um sujeito que pudesse compor com o trabalho, mas também se tinha clareza de que ninguém poderia assumir o papel do professor frente ao processo educativo.

Ainda no ano de 2008, foram contratados 30 agentes sociais de inclusão que passaram a prestar serviço apenas nas unidades que de fato tinham alunos com deficiências mais comprometedoras. Entendia-se que estes alunos, sendo dependentes por conta de necessidades advindas de suas deficiências, necessitavam de apoio direcionado e que, portanto, os professores necessitavam de um parceiro.

É nesse contexto que mais uma demanda mapeada pelo CADE é atendida pela Secretaria de Educação quando estabelece parceria com a Fundação Santo André e os alunos com dificuldades de aprendizagem passam a ser encaminhados para a referida instituição e avaliados por uma equipe clínica e terapêutica. É válido recolocar que a partir da queixa escolar sobre as "dificuldades de aprendizagem", os alunos só eram encaminhados para avaliação na Fundação Santo André após a equipe do CADE ter promovido reflexões com a professora deste aluno acerca dos diferentes aspectos do seu desenvolvimento.

A esse respeito, Patto (1997, p. 292) afirma que "muitos educadores têm uma idéia fragmentária, professores e diretoras tendem a atribuir o baixo rendimento da escola à incapacidade dos alunos e ao desinteresse e desorganização de suas famílias". Portanto, a equipe do CADE preocupava-se quanto a possibilidade de que os diagnósticos tivessem o poder de rotular os alunos ao invés de se tornar um instrumento de informação a respeito das reais necessidades (psicológica, fonoaudiológica, psicopedagógica e outras) que, sendo mapeadas no sujeito, indicava necessidade de atendimento clínico e terapêutico.

Predominantemente, nesse momento da história do CADE, tinha-se clareza da importância e necessidade de investimentos direcionados à formação dos pais, professores, professores assessores, equipes técnicas, diretivas e ASIs. As formações problematizavam a diversidade; preconceitos e aspectos das necessidades decorrentes das deficiências eram constantes. 
No ano de 2009, nova gestão administrativa assume a Secretaria de Educação, sendo preciso que a equipe do $\mathrm{CADE}$ caminhasse concomitante às mudanças, porém entendendo que não se tratava de rupturas, mas sim, de possibilidades de transformação.

O primeiro desafio era preservar integralmente a continuidade da equipe, uma vez que todos tinham sido privilegiados com formações nas especificidades técnicas no campo das deficiências ao longo dos nove anos de existência do CADE.

Na seqüência, buscando caminhos para garantir a continuidade e sustentação de suas ações, a equipe de professores assessores do CADE elabora o "Contrato de Grupo" através de estudos e discussão coletiva.

Nesse documento, busca-se registrar as ações objetivadas a partir dos princípios norteadores, que sinalizaria às escolas ser necessário considerar que:

\begin{abstract}
Uma criança quando nasce, seja lá onde for, tem condições suficientes de estímulos para se realizar plenamente como gente, tanto assim é que aprende a olhar o mundo, a ouvir, a reagir, a andar, a mexer, com as coisas, a construir coisas... e a falar! Essas coisas em si são muito pessoais, individuais, e a sociedade deixa isso acontecer naturalmente, como algo esperado, diria mesmo, esperado biologicamente, como se fosse uma herança hereditária da raça humana, da qual compartilham todos. Os que por alguma razão nasceram com deficiências biológicas gravíssimas - o que acontece muito raramente- apresentam restrições de vida, sem dúvida, mas mesmo para estes, em muitos casos, a deficiência biológica não impede completamente sua locomoção, a reflexão, o fazer e o falar. (CAGLIARI, 1997, p. 195).
\end{abstract}

Em linhas gerais, vale colocar que se entendia que os professores da rede municipal de ensino necessitavam de formações e que os agentes formadores continuariam sendo os integrantes da equipe do CADE, quando então o "Contrato do Grupo", construído a partir de uma perspectiva de gestão participativa, é problematizado por todos. Todos os profissionais do CADE envolvidos no processo, puderam se posicionar, reflexionar, clarificar e registrar no coletivo, suas concepções, ações e demandas enquanto profissionais que de maneira bastante desafiadora, circulariam pelo município tendo como função articular o processo educacional numa perspectiva "inclusiva", lidando com diferentes frentes e sujeitos, sendo eles: equipes diretivas, funcionários das escolas, profissionais clínicos e terapêuticos, famílias, professores e alunos.

\footnotetext{
${ }^{6}$ O Contrato de Grupo foi elaborado pelos professores assessores de educação inclusiva, no início do ano letivo de 2009, quando os profissionais do CADE, Centro de Atenção ao Desenvolvimento Educacional, entendiam a necessidade e importância de elaborar, unificar e registrar suas ações para que as mesmas pudessem ser encaminhadas à rede de ensino e, após analisadas, pudessem ser incorporadas ao Projeto Político Pedagógico da escola. Este Contrato de Grupo clarificava e problematizava as ações formativas e intenções de parceria da equipe do CADE com as equipes diretivas, equipes clínica e terapêutica, pais, professores, ASIs e todos os representantes das UEs, tendo, por princípio, a inclusão de todos os alunos na escola. Dessa maneira, o Contrato de Grupo pretendia ser um documento norteador, objetivando ações que pudessem viabilizar e qualificar o processo de Educação para todos dentro da Rede Municipal. O mesmo segue anexo.
} 
Após construído, o "Contrato do Grupo", deixa clarificado suas objetivações, devendo em seguida ser enviado às unidades escolares para ser analisado pelos professores e demais profissionais da escola. Na perspectiva de qualificação do processo, buscavam-se sinalizar caminhos de superação frente aos desafios da escola, sugerindo que esse documento fosse analisado e anexado ao Projeto Político Pedagógico de cada unidade de ensino. Em sua essência, esse documento propunha que a equipe do CADE buscasse, em parceria formativa com as escolas, favorecer o envolvimento e o desenvolvimento dos alunos numa perspectiva de educação para todos. No entanto, é engavetado ${ }^{7}$, não legitimando a essência do seu teor que era ser "incluído" nas discussões dos Projetos Políticos e Pedagógicos de forma a envolver à todos no processo, promovendo assim participação proativa.

No que se referia as demandas dos alunos com dificuldades de aprendizagem, em 2009, a partir da gerência do CADE, reinicia-se interlocução com a Fundação Santo André, especificamente através da equipe da Neurodificuldades.

Naquele momento da parceria, tem-se como objetivo que todas as unidades escolares do município, após intervenção reflexiva das professoras assessoras, pudessem encaminhar alunos com dificuldades de aprendizagens que seriam avaliados pela equipe multidisciplinar e, após levantamento de suas necessidades, seriam atendidos pela mesma.

Concomitante a esse processo de atendimento e acompanhamento, entendia-se ser necessário que tanto os profissionais da saúde quanto os professores dos alunos em tratamento pudessem travar um diálogo reflexivo e formativo sobre o desenvolvimento do aluno acompanhado. Ao delinear o projeto, buscava-se avaliar a dimensão da medicalização do processo ensino e aprendizagem quando todos os profissionais envolvidos reflexionariam e se posicionariam buscando contribuir a partir da problematização do desenvolvimento do aluno na sua totalidade. Nessa perspectiva, todos os professores dos alunos encaminhados e as assistentes pedagógicas das referidas unidades, participariam do processo de formação com a equipe do CADE e da Fundação Santo André.

Tal processo tinha por objetivo o estudo sobre as dificuldades de aprendizagem como dislexia, dislalia, entre outros. Entendia-se a importância desta formação sendo movimentada pelos profissionais do CADE em parceria com as assistentes pedagógicas, os professores dos alunos avaliados, equipe clínica e terapêutica. Compreendia-se que ao analisar as dificuldades de aprendizagem de maneira fragmentada, não focada na relação com a

\footnotetext{
${ }^{7}$ A construção do Contrato de Grupo se dá num momento conturbado da nova gestão e por motivos de ordem política não tão claros, o mesmo deixa de ser encaminhado às unidades escolares, fato que inviabiliza sua análise pelo coletivo escolar.
} 
pedagogia, compunha-se com modelos reducionistas que de maneira equivocada tratam os problemas de modo isolado e projetado no aluno. Sobre tal aspecto, Tanamachi (2000, p. 78) declara que "ao centrarem no aluno a responsabilidade pelo seu fracasso, justificam assim o status quo da própria educação" e este processo precisava ser superado.

Neste momento, estava clarificado para os profissionais do CADE a importância da articulação do processo de educação inclusiva na totalidade quando questionava-se como os alunos e suas famílias reagiam ao fracasso escolar. As preocupações se davam em torno da problematização do modo como as equipes escolares e os professores desses alunos os percebiam e os compreendiam diante do quadro de dificuldades de aprendizagem. A equipe perguntava-se em que dimensão concebia-se a patologização do desempenho escolar.

No entanto, no ano de 2010, mudanças no formato de trabalho são comunicadas à equipe de professores assessores quando, concomitante a estas, os mesmos são deslocados do prédio que era destinado para centralizar todo o encadeamento de suas ações e reuniões, passando então a não ter mais um local fixo destinado para a realização das suas demandas organizacionais, formativas e administrativas. Nesse mesmo ano, 30\% dos profissionais do CADE se deslocam para outras funções, acarretando um déficit significativo no quadro de professores assessores de educação inclusiva.

Com o quadro reduzido (contando com 20 professores assessores de educação inclusiva) essa agência do governo local tenta suprir as necessidades advindas da rede municipal de ensino que agora contava com aproximadamente 900 alunos com deficiência, matriculados em 93 unidades. É válido acrescentar que naquele momento, quando se deu a redução do número de professores assessores de educação inclusiva, no mesmo período, a Secretaria de Educação, investe na ampliação do quadro de Agentes Sociais de Inclusão, passando de 30 para 64 ASIs.

Naquele momento, os Agentes Sociais de Inclusão, assumem papel relevante para a rede de ensino e mediante esse processo, são solicitados cada vez mais pelas equipes das escolas e até mesmo pelos próprios professores assessores de educação inclusiva, que vêem na atuação desse profissional uma possibilidade de dar respostas imediatas e simultâneas às queixas de desconforto advindas dos sujeitos da escola, frente às manifestações dos alunos com deficiência.

$\mathrm{Na}$ medida em que se amplia e dá-se ênfase para o papel dos Agentes Sociais de Inclusão e diminui-se o número de professores assessores de educação inclusiva, as possibilidades de reflexão teórica sobre as necessidades educativas especiais são reduzidas, criando novas necessidades a serem problematizadas. 
Em decorrência da ênfase do trabalho do ASI em detrimento ao trabalho dos PAEIs, as ações vinculadas às necessidades educativas passam para a dimensão de atendimento às necessidades imediatas. A parceira estabelecida com a Fundação Santo André, que inicialmente buscava enfatizar as possibilidades educativas após o processo de diagnóstico numa perspectiva de formação, passa a ser requisitada cada vez mais para colocar em movimento o diagnóstico e o tratamento.

O desvelamento do cotidiano escolar aponta para a complexidade das relações estabelecidas entre o ensino e aprendizagem, porém, as perguntas permanecem sem respostas, pois o modelo patologizante de interpretação do processo educacional não é questionado, ao contrário, intensifica-se assim a produção de diagnóstico e o atendimento terapêutico como se estes pudessem dar respostas à educação sobre os motivos que levam o aluno a não aprender. Tal movimento sugere pensar que os profissionais da educação não precisam se perguntar quais relações e situações vividas na cotidianidade escolar são produtoras do não aprendizado dos seus alunos. Souza contribui nesta reflexão declarando que:

Tais relações envolvem aspectos da política educacional, da organização
institucional, da formação de professores, das histórias individuais e profissionais,
das relações da escola com os pais e destes com a escola, da relação face a face da
sala de aula, da constituição de grupos em sala de aula [...] esse conjunto de relações
entrelaçam na história escolar de cada criança e na história profissional de cada
professor. Considerando que as relações escolares são produzidas no contexto
escolar, como conhecê-las, como apreendê-las? (SOUZA, 2000, p.3)

O CADE, ao restringir suas ações e formações nas áreas da deficiência distanciando-se assim de formações a partir do caráter dialético da educação fundamentado ao longo da sua própria história enquanto agência formadora, evidencia sua fragilidade e equívocos frente a sua função social. Tal fato, segundo Meira (2000, p. 52), denota "o quanto a sociedade moderna impede, das diferentes formas, sua emergência e desenvolvimento [...] sendo preciso estar atentos para o gradativo desaparecimento das forças críticas na sociedade capitalista $[\ldots] "$.

Sabe-se que a interpretação do processo educacional a partir de modelos patologizantes da educação precisam ser superados, no entanto, no decorrer de sua história, o CADE retrocede quando, tentando responder as demandas da educação de maneira imediatista, inaugura em 2012 o CAEM - Centro de Atendimento Educacional Multidisciplinar -, quando, representado pela atual gerência da educação inclusiva através da Secretária de Educação, declara que: 
O CAEM irá fortalecer a parceria entre Educação e Saúde, concentrando avaliações e atendimentos clínicos em espaço educacional [...] Os trabalhos realizados com alunos deficientes e com transtornos funcionais específicos, como dislexia e hiperatividade, serão agora concentrados no CAEM. No espaço haverá psicólogos, fonoaudiólogos e psicopedagogos. Além disso, os profissionais irão atuar na orientação familiar e formação nas unidades escolares. [...] Os estudantes que chegam sem diagnóstico nas escolas passam por avaliação e anamnese (procedimento inicial para detectar disfunção de saúde), feitas pelos profissionais das unidades escolares e equipe da gerência de Educação Inclusiva [...] (SANTO ANDRÉ, 2012, p.1)

Esse atendimento clínico e terapêutico que adentra o espaço educacional não dá ênfase à ação pedagógica, pois distancia sutilmente o professor da percepção e compreensão de como esta produção do fracasso escolar foi engendrada no cotidiano escolar.

Nessa nova perspectiva, isenta-se o sistema econômico, político e social da sua responsabilidade pela produção e reprodução da desigualdade social, pois numa tentativa pseudodrámatica de resgate do sujeito, oferece-se o atendimento terapêutico projetando a causa do problema nas suas características individuais, responsabilizando assim o sujeito por aquilo que acontece a ele. Desconsidera-se, portanto, o território no qual os sintomas foram construídos, fragilizando assim as relações estabelecidas, inclusive dentro dos muros da escola.

É válido acrescentar que, mesmo sendo denominado como Centro de Atendimento "Educacional" e estando sediado dentro dos muros da escola, esse equipamento não conta em sua equipe, com a parceria de professores, sendo constituído por psicólogos, fonoaudiólogos e psicopedagogos que, de acordo com a declaração da representante da Secretaria de Educação, passam a orientar as famílias e a oferecer formações às escolas. Dessa maneira, é importante ressaltar que, ao se distanciar do seu objetivo central, a formação de professores, a equipe de professores assessores do CADE se distancia também da possibilidade de cumprir integralmente sua finalidade quando deixa de problematizar questões emergentes de sua prática à luz dos avanços teórico-críticos já conquistados até então.

Toda equipe limita-se a atuar em direção a questões necessárias, porém secundárias, que na melhor das hipóteses se dão na execução de formações sobre as deficiências, adequações de materiais específicos e indicações de atividades adaptadas para alunos com deficiência e remanejamento dos ASIs. No entanto, sabe-se que essencialmente os professores estão necessitados de profissionais que possam se envolver de fato com tarefas de reflexão teórico-prática em uma perspectiva crítica quando as formações devem colocar, antes de mais nada, as finalidades das ações dos educadores e a real função da escola para todos. 
Acredita-se que, com clareza sobre sua identidade e finalidade, o CADE, enquanto agência formadora poderá contribuir significativamente se eleger a "Educação" como objeto de reflexão e ação, quando poderá oferecer aos professores subsídios teórico práticos, contribuindo para a consolidação de conhecimento que favoreça a todos os sujeitos, pois na escola, esses sujeitos estão inseridos em um processo fundamental de humanização; momento em que estes podem apropriar-se do conhecimento e dele fazerem uma ferramenta que potencialize seu desenvolvimento.

Em conformidade com Meira (2000, p. 66) acredita-se que "é fundamental que os profissionais construam sua intervenção a partir do conhecimento profundo das multideterminações presentes no encontro entre o sujeito humano e o processo educacional", quando, diante dessa perspectiva, este estudo pretende na continuidade analisar as relações estabelecidas entre os profissionais do CADE, a gestão de política pública e os profissionais de educação da rede municipal de ensino de Santo André, na tentativa de analisar as possibilidades e os limites de atuação frente ao que está instituído neste momento histórico diante do movimento educacional inclusivo. 


\section{A INVESTIGAÇÃO NA REALIDADE DA EDUCAÇÃO INCLUSIVA}

Neste capítulo expõe-se o contexto no qual a pesquisa foi desenvolvida e explicase como a mesma foi organizada, revelando os procedimentos metodológicos para a apreensão da realidade investigada.

Para apresentar o objetivo desta pesquisa, recorre-se a Bernardes (2012, p. 20), ao declarar que "o movimento de constituição dos professores e de seus estudantes ocorre de forma dialética, ou seja, ambos implicam no processo de transformação da consciência uns dos outros". Nesse alinhamento reflexivo, tem-se como objetivo, a análise dos limites e das possibilidades que a política pública de Educação Inclusiva cria para a ação pedagógica do professor e do professor assessor no cotidiano escolar, entendendo que estes também se implicam nos seus processos de transformação enquanto sujeitos da educação pela relação que estabelecem.

É válido recolocar que, neste estudo, compreende-se que os sujeitos professor e professor assessor de educação inclusiva estão cotidianamente ligados a partir da ação pedagógica que desencadeiam, com o objetivo de atender às necessidades advindas dos alunos com deficiência e/ou com dificuldades de aprendizagem visto se tratar de um processo educacional inclusivo.

Dessa forma, enquanto processo analítico, será problematizada a relação escola e professor assessor bem como a relação entre este último e a gestão pública. Sabe-se existir limites e possibilidades que são criados pela relação da gestão pública com o trabalho do professor assessor, assim como existem possibilidades e limites postos na relação professor assessor e escola. Sabe-se também que estas relações não são dissociadas, mas estão intimamente imbricadas. No entanto, para efeito de análise da realidade concreta, os dados da pesquisa serão divididos em três segmentos como segue abaixo:

- limites e possibilidades dadas a partir da gestão de política pública;

- limites e possibilidades de atuação da professora assessora e da professora assessorada no contexto da educação inclusiva;

- limites e possibilidades do professor assessor na atuação junto ao coletivo da escola

Embasados pelos fundamentos teóricos propostos pela pedagogia histórico-crítica e psicologia histórico-cultural, a partir de Tanamachi (2011), sabe-se da necessidade de interpretar a realidade e, para tanto, a exigência é da localização da relação sujeito-objeto buscando compreender como o professor e o professor assessor se relacionam, a partir da 
gestão da política pública com as necessidades que surgem no cotidiano da educação inclusiva.

Nessa perspectiva, sabe-se que a linha teórica que orienta e sustenta esta pesquisa permite explicar a realidade concreta ao considerar o caráter material da existência humana e a historicidade dos sujeitos a partir da lógica dialética. Segundo Tanamachi (2011, p. 5), "entendemos como lógica dialética o processo de conhecimento sobre a realidade que permite reconhecer o movimento e as contradições nas relações entre os homens e suas formas de organização [...]".

Dessa forma, diante das funções assumidas pelo professor e professor assessor na realidade concreta da educação inclusiva, busca-se a compreensão acerca dos limites e possibilidades de atuação de ambos, cuja finalidade é apontar caminhos possíveis para a superação do que está instituído.

\subsection{A realidade concreta e os sujeitos no movimento da pesquisa}

Apresenta-se o universo da pesquisa declarando que seu campo de investigação é a cidade de Santo André, município que integra o $\mathrm{ABC}$ paulista, localizado na região metropolitana de São Paulo. A população daquele, de acordo com o último censo realizado pelo IBGE - Instituto Brasileiro de Geografia e Estatística, divulgado em dezembro de 2011, atinge um índice de 676 mil habitantes.

Coloca-se que o município conta com diferentes serviços culturais. Um deles, localizado na região central, é a Casa da Palavra, um espaço reservado a atividades relacionadas a manifestações da palavra a partir da escrita e da fala. Outro destaque da cidade é o Museu de Santo André Dr. Octaviano Armando Gaiarsa que conta com acervo histórico, formado por objetos, fotografias, documentos, livros, jornais e revistas, além de exposições temáticas que são abertas à população.

A Escola Parque do Conhecimento Sabina é outro espaço cultural e educacional da cidade, sendo prioritariamente destinado aos alunos e professores do município. Neste espaço, são oportunizadas experiências educativas e o debate sobre assuntos relacionados ao mundo das ciências, artes e tecnologia. A Escola Parque do Conhecimento Sabina foi construída em uma área que abriga entre demais atrações, um aquário com diferentes peixes, arraias e tubarões, um pinguinário, além de réplicas de dinossauros. Outro destaque dentro do 
município é o Parque Escola, sendo também um espaço educativo atrativo uma vez que conta com bosque, bromeliário, cactário, diversificadas plantas ornamentais, aromáticas e ervas medicinais, além de plantas suculentas e um espaço destinado à criação de bicho-pau.

Nesse contexto, coloca-se que o Sistema Municipal de Ensino de Santo André conta com 51 Escolas Municipais de Educação Infantil e Ensino Fundamental (EMEIEFs), 10 Centros Educacionais (CESAs), 5 Centros Públicos de Educação de Jovens e Adultos (CPEJAs), 31 Creches Municipais e 18 Creches Conveniadas.

Os alunos munícipes estão distribuídos em diferentes modalidades de ensino, sendo elas: Educação Infantil, Ensino Fundamental I e Educação de Jovens e Adultos e nesse formato a cidade de Santo André administra 115unidades escolares.

Nas creches, os alunos são atendidos antes de completarem o primeiro ano de vida e são acompanhados até atingirem idade para serem matriculados no Ensino Fundamental I, sendo então transferidos para as EMEIEFs, onde cursam até o $6^{\circ}$ ano.

$\mathrm{Na}$ modalidade de Educação de Jovens e Adultos (EJA), os alunos contam com aulas em 25 EMEIEFs e em 5 Centros Públicos, onde nesses últimos, lhes são disponibilizadas vagas em diferentes cursos profissionalizantes como manicure, auxiliar de serviços, podologia, pedreiro, eletricista, pintor, auxiliar de cozinha, informática básica e avançada e outros.

Os CESAs - Centros Educacionais de Santo André - concentram-se em um só lugar, espaço destinado à creche, EMEIEF e Centro Comunitário, com área para caminhada, parques, quadra e ainda programação de atividades culturais, esporte e lazer para a comunidade e os alunos, podendo ser denominados como sendo complexos educacionais.

Dentro desse universo, o governo municipal de acordo com Santo André (1997), sinaliza a intenção de concretizar um projeto político-pedagógico que contribua com a construção de uma cidade democrática. Desta forma, em 1997, através da Secretaria de Educação e Formação Profissional, implementou o Programa de Educação Inclusiva, como já foi colocado no capítulo anterior. No entanto, é válido retomar que o Programa de Educação Inclusiva, desde 1997, fora desenvolvido a partir da elaboração de um plano de trabalho com o objetivo de proporcionar acesso, permanência e qualidade educacional às crianças, jovens e adultos. 
Segundo dados da Secretaria de Educação do município de Santo André, até o final de $2011^{8}$, encontram-se matriculados nas escolas municipais 936 alunos com deficiências ou transtornos, divididos nas categorias de deficiência intelectual, deficiência física, deficiência auditiva, pessoa com surdez, deficiência visual, pessoa com cegueira, transtorno global do desenvolvimento, deficiência múltipla e surdocegueira.

Desse total de 936 alunos, 193 fazem parte da Educação Infantil, 499 frequentam o Ensino Fundamental I e 244 estão matriculados na Educação de Jovens e Adultos. É válido indicar que nesse mesmo ano, Santo André conta com 11 salas de recursos multifuncionais em conformidade com o preconizado no Atendimento Educacional Especializado.

Como já indicado no capítulo anterior, desde 2003 eu fazia parte da assessoria do Centro de Atenção ao Desenvolvimento Educacional (CADE), sendo que no ano de 2011, atuando enquanto professora assessora iniciei a presente pesquisa.

No exercício da minha função, no período de levantamento dos dados para esta pesquisa, atuava em uma creche, três EMEIEFs e também no Centro de Formação dos Professores. Na itinerância, uma vez por semana, apresentava-me a um destes espaços para junto com os professores analisar as demandas e o desenvolvimento pedagógico dos alunos com deficiência. Convém retomar que a atribuição do professor assessor, segundo Santo André (2001, p. 1), é “auxiliar o professor no diagnóstico das dificuldades relativas ao ensino e a aprendizagem, apresentadas prioritariamente aos alunos com necessidades educativas especiais". Dessa forma, nos encontros semanais, tinha como objetivo, problematizar com os profissionais da escola, o planejamento pedagógico, as necessidades de viabilização de materiais que garantissem equiparação de oportunidades e também debatíamos sobre os desafios diante da tentativa de implantação de uma cultura inclusiva.

O Centro de Formação de Professores Clarice Lispector era um dos locais onde aconteciam as reuniões de grupo, às segundas-feiras. Nesses encontros (semanais ou quinzenais), a equipe de professoras assessoras de educação inclusiva, levantava as demandas das escolas e discutia as necessidades, desafios e elaborava as possibilidades de trabalho.

$\mathrm{Na}$ creche, havia apenas três crianças com deficiência matriculadas, todas, segundo seus pais, professores e equipe clínica e terapêutica, em franco processo de desenvolvimento.

\footnotetext{
${ }^{8}$ Os dados desta pesquisa referem-se ao ano de 2011, pois neste mesmo período ingresso no Programa de PósGraduação - ProMuSPP, passando a realizar esta pesquisa concomitante ao exercício de professora assessora de educação inclusiva no município de Santo André.
} 
Nas três EMEIEFs os profissionais apresentavam-me uma demanda maior, pois em se tratando de quantidade de alunos com deficiência, todas elas tinham em média 17 alunos matriculados e distribuídos nas três modalidades de ensino: educação infantil, ensino fundamental I e educação de jovens e adultos, sendo que estes estudavam em diferentes turnos: manhã, tarde e noite. Tal fato me exigia, tempo e condições para assessorar os três turnos destas unidades.

Nas EMEIEFs também aconteciam reuniões pedagógicas semanais com todos os professores no período noturno. É necessário declarar que, enquanto PAEI, desde o início da minha função, entendia ser importante participar destas reuniões pedagógicas para poder oferecer escuta aos professores dos alunos com deficiência. No entanto, a partir dos estudos realizados no GEPPESP (Grupo de Pesquisa Educação, Sociedade e Políticas Públicas: concepções da teoria histórico-cultural), alarga-se minha compreensão de que nas reuniões pedagógicas, poderia, de maneira sistematizada e reflexiva, articular coletivamente com os profissionais da escola, sua função social e suas possibilidades de contribuição frente ao processo pedagógico. Esse posicionamento refere-se ao que Machado (2007, p. 163) indica ser necessário no encaminhamento de soluções às demandas da escola, visto que "a queixa escolar é constituída em uma história coletiva. Avaliar a produção da queixa escolar implica buscar o quanto é possível alterar essa produção, afetando os fenômenos nos quais ela se viabiliza".

Nessa perspectiva, a minha presença enquanto pesquisadora na escola de maneira sistemática seria essencial. Segundo Asbahr (2011), a permanência prolongada em campo intensifica qualitativamente a convivência entre a pesquisadora e o grupo pesquisado. Dessa forma, elege-se uma das EMEIEFs quando, concomitantemente atuando como PAEI e como pesquisadora, poderia analisar com mais profundidade as demandas e manifestações dos profissionais, pois estaria presente e próxima a todos.

A partir destas considerações, esta pesquisa acontece em uma escola municipal de educação infantil, ensino fundamental e educação de jovens e adultos instalada na periferia do município de Santo André, localidade onde há elevado índice de trabalhadores com baixa renda.

Dessa maneira, os motivos que determinam a identificação da escola e da professora que faz parte da pesquisa referem-se a diferentes aspectos anunciados abaixo, sendo eles: 
- $1^{\circ}$ critério: As demandas advindas da unidade de ensino indicavam necessidades e possibilidades de contribuição frente às discussões e encaminhamentos para a educação inclusiva, ao mesmo tempo em que o levantamento de dados se daria simultaneamente às intervenções realizadas;

- $2^{\circ}$ critério: Nessa unidade, havia alunos matriculados nas salas com deficiência intelectual e com dificuldades de aprendizagem;

- $3^{\text {o }}$ critério: A professora que era acompanhada por mim enquanto professora assessora de educação inclusiva demonstrou interesse em participar na pesquisa e se disponibilizou a problematizar a sua função social numa escola de educação inclusiva;

- $4^{\circ}$ critério: A professora integrante desta pesquisa manifestava desconforto frente às manifestações de um determinado aluno com dificuldades de aprendizagem sendo que uma das queixas se dava em torno ao fato de que grande parte das famílias dos alunos com deficiência ou dificuldades de aprendizagem, muitas vezes não acompanhavam o processo educativo do seu filho;

- $5^{\circ}$ critério: A professora se queixava da pouca oferta de formações;

- $6^{\circ}$ critério: A professora além de se dispor a participar, estava atuando numa classe com demanda adequada ao objeto da pesquisa;

- $7^{\circ}$ critério: Segundo a equipe escolar e a professora, o aluno com dificuldades de aprendizagem, precisaria ser avaliado pela equipe clínica e terapêutica da Fundação Santo André, pois o mesmo precisava de um diagnóstico e de tratamento. Essa necessidade sinalizada pela escola indicava a importância de problematização sobre tal processo.

Dessa maneira, na unidade de ensino participante da pesquisa a observação das manifestações dos profissionais da educação, coleta de dados e registros diversos se deu 
durante todo o ano letivo de 2011, período em que eu enquanto pesquisadora e assessora estive em contato direto com a professora, agente social de inclusão, alunos, pais, equipe diretiva e equipe clínica e terapêutica que atendiam os alunos com deficiência.

Naquele período, semanal ou quinzenalmente, era agendado um encontro com a professora que passava a ser acompanhada de forma mais próxima, possibilitando o registro dos dados de pesquisa a partir da ação pedagógica. É importante destacar que tanto a ação pedagógica da professora quanto da professora assessora foram registradas ao longo da pesquisa. Tais registros e as proposições dessa estratégia serão problematizados ao longo do capítulo.

Clarifica-se que na sala de aula integrada à pesquisa, estava matriculada uma aluna com 6 anos e com diagnóstico de deficiência intelectual. Nesse caso, as manifestações de inquietação e questionamentos da professora eram constantes, e foram se agravando na medida em que mesmo sendo assídua e se mostrando receptiva às propostas pedagógicas, a aluna não conseguia se apropriar da rotina e dos espaços da escola. Segundo a professora, a aluna não sabia explorar o caderno, usar o banheiro sozinha e não tinha autonomia nem para se alimentar. Essa aluna era acompanhada por uma agente social de inclusão que atendia as necessidades apresentadas pela aluna no que se referia a higiene, alimentação e outros cuidados pessoais. Em muitos momentos, também auxiliava durante a realização das atividades pedagógicas.

Nessa mesma turma havia um aluno, também com 6 anos, que sofria violência doméstica, fora abrigado em lar assistencial e que também despertava angústias na professora pois, durante as aulas, muitas vezes, quando irritado, batia nos colegas, na professora e se recusava a participar das atividades propostas. Era recorrente a queixa de sua professora quanto ao fato do mesmo fugir da sala de aula e manifestar muita resistência para retornar. Esse aluno também apresentava distúrbio de fala, e sempre que a professora tentava se comunicar com ele, mostrava-se frustrada por não conseguir obter informações sobre o que ele estava sentindo e sobre quais os motivos o faziam querer afastar-se do grupo.

Sempre que me apresentava à escola, era procurada pela professora para problematizar o comportamento do aluno. A professora alegava que era difícil lidar com a situação, pois o aluno já havia batido nela e em outros colegas e não havia ninguém da família que pudesse ajudá-la a compreender melhor o que estava acontecendo com ele. Nesses momentos, era solicitado o encaminhamento do aluno para avaliação diagnóstica.

$\mathrm{Na}$ tentativa de contribuir e de exercer minha função enquanto professora assessora da educação inclusiva, comecei a questionar-me quanto à escassez de profissionais 
no CADE, visto que $30 \%$ da equipe, no ano de 2010 , deixam a função de professor assessor de educação inclusiva, quando, então, 10 vagas não são preenchidas.

Ao longo de 2011, preocupava-me a constatação de que profissionais destinados ao trabalho formativo (tão necessário e ao mesmo tempo tão esperado pelos profissionais da educação) deixassem de ser contratados. Como já colocado, apenas 20 professores assessores de educação inclusiva passam a atender toda a rede municipal de ensino.

Mesmo sobrecarregada pela demanda, mantenho-me inquieta e atenta às manifestações dos professores quando intensifico minha dedicação ao atendimento às queixas trazidas por estes.

Tendo como objetivo problematizar os limites e as possibilidades da ação pedagógica do professor e do professor assessor frente ao processo educacional inclusivo, feito o destaque ao contexto da pesquisa, é necessário acrescentar que a professora e a professora assessora de educação inclusiva foram o foco da mesma, pois estas estavam diretamente em contato com os alunos com e sem deficiência, articulando assim, as demandas advindas da diversidade da sala de aula.

Coloca-se que embora a função social do professor seja uma questão já há muitos anos problematizada, no exercício da minha função enquanto professora assessora de educação inclusiva entrei em contato com manifestações de fragilidades, pois muitos professores, diante dos alunos com necessidades educacionais especiais, alegam não saber o que fazer. Essa fragilidade diante da função social de educador é sinalizada por Rocha (2000, p. 193) da seguinte forma: "os educadores preocupados com o fracasso escolar em nosso país, sentem-se culpados quando o sistema se desmonta em suas mãos”.

Nessa direção, no exercício da assessoria, foi possível constatar que profissionais da educação, através de ações e discursos, demonstravam pouca compreensão sobre os fenômenos manifestados no cotidiano escolar. Professores fragilizados sinalizavam a urgente necessidade da problematização da função social que exerciam, principalmente frente às manifestações e demandas dos alunos com deficiência e com dificuldades de aprendizagem. Diante desse cenário, a partir de Abramowicz entende-se que:

[...] a escola tem sido utilizada para tantas coisas, tantas exigências (merenda, campanhas das mais variadas, ensino religiosos etc.) que anda perdida diante de tanta multiplicidade. Tudo isso não teria importância se as professoras não tivessem ficado tão sozinhas no cotidiano: com um salário tão irrisório, com as escolas tão empobrecidas (tanto as que cursaram para se formar, quanto as condições estruturais das escolas que atuam). A escola não tem podido cumprir com tantas tarefas a ela atribuídas, e depositar tantas funções na escola é uma estratégia para que tudo dê errado. A escola tem produzido 'desertores' e analfabetos. (ABRAMOWICZ, 1997, p. 166) 
Diante dos fatos mencionados ao longo desse texto, constata-se, que a cultura da exclusão instalou-se na escola quando, as manifestações declaradas, indicam a importância de intensificar reflexões acerca deste fenômeno. Portanto, ao longo da pesquisa, surge a necessidade de análise das possibilidades e limites que a política pública de Educação Inclusiva cria para a ação pedagógica do professor e do professor assessor uma vez que este se apresenta às escolas enquanto agente formador, na tentativa de propor caminhos para a superação do que está instituído.

Entendendo que as condições de existência a partir das questões sociais, econômicas, políticas e culturais por vezes são potencializadoras ou limitadoras da condição humana, concorda-se que toda atividade humana parte de uma necessidade e surge a partir de um motivo. Segundo Bernardes (2009, p. 239), quando os sujeitos estão em atividade "o motivo e o objetivo correspondem à necessidade de humanização dos indivíduos na relação com o gênero humano". Dessa forma, o motivo que me conduz a pesquisar a minha ação pedagógica enquanto professora assessora de educação inclusiva se dá no momento em que percebo que, no movimento caótico das escolas, eu, reproduzia o discurso hegemônico sobre incluir alunos, bem intencionada, mas de maneira equivocada.

No decorrer do exercício da assessoria, começo a questionar-me sobre quem são os excluídos ou incluídos no sistema público de ensino, buscando reflexionar sobre as manifestações dos alunos com ou sem deficiência, dos seus professores e dos professores assessores de educação inclusiva, passando então a compreender os processos de inclusão e exclusão enquanto produção social. Tal constatação coloca-me as necessidades: transformarse e contribuir para transformar o meio pela ação pedagógica.

$\mathrm{Na}$ busca por respostas, deparo-me com a contraposição de conceitos dentro/fora, incluído/excluído, conceitos que permeiam o processo pois, como já colocado, inclusão e exclusão se manifestam a partir da lógica do sistema educacional independente de haver alunos com deficiência matriculados no mesmo.

Este movimento remete a reflexões sobre a minha função social e a função social dos professores frente ao desafio da educação inclusiva quando os equívocos, as inquietações, medos e estranhezas podem ser compreendidos se levarem-se em conta algumas questões, tais como a constituição dos sujeitos e as marcas sociais e culturais impregnadas no sistema capitalista, que obscurecem a possibilidade de reflexão e consequentemente, de superação do processo alienante ao qual nos integramos. Na tentativa de esclarecimento sobre processo de alienação, recorre-se a Heller, ao declarar que: 
[...] alienação é sempre alienação em face de alguma coisa e, mais precisamente, em face das possibilidades concretas de desenvolvimento genérico da humanidade [...] a vida cotidiana de todas as esferas da realidade, é aquela que mais se presta à alienação [...] na cotidianidade, parece 'natural' a desagregação, a separação de ser e essência. (HELLER, 1985, p. 37)

$\mathrm{Na}$ condução da linha teórica que sustenta esta pesquisa, passa-se então a compreender a necessidade de análise da ação pedagógica frente às demandas da educação inclusiva.

Desta maneira, enquanto pesquisadora entende-se que para objetivar o fim almejado nesta pesquisa, não bastava interpretar a realidade somente a partir da ação pedagógica do professor da sala de aula. Também seria necessário analisar a minha ação pedagógica enquanto professora assessora de educação inclusiva para que, em parceria, pudéssemos debater, analisar, explicar e apontar caminhos para superação e transformação do movimento instituído na escola.

Ao perceber a evidente necessidade de análise da minha ação pedagógica, são traçados novos objetivos para o meu exercício enquanto professora assessora e pesquisadora. Essa ação relaciona-se ao que Vázquez (1977, p. 189) afirma quando coloca que "pelo fato de propor-se objetivos, o homem nega uma realidade efetiva, e afirma outra que ainda não existe. Mas os fins são produto da consciência, e por isso a atividade que eles governam é consciente".

Passo a entender a necessidade de mudança das condições particulares dentro dos limites da assessoria que até então só me possibilitavam olhar a realidade social da educação inclusiva na sua aparência. Diante das condições existentes para o exercício da minha função, avaliei que minhas ações precisariam ser planejadas e adequadas para que se tornasse possível captar a realidade da educação inclusiva nas suas múltiplas determinações. Entendia ser necessário problematizar com os professores a função social da escola quando planejamento e formações precisavam ser articulados.

Diante de reflexões e inquietações, encontro em Vázquez subsídio teórico quando este afirma que:

[...] se o homem aceitasse sempre o mundo como ele é, e se, por outro lado, aceitasse sempre a si mesmo em seu estado atual, não sentiria a necessidade de transformar o mundo nem de transformar-se. O homem age conhecendo, do mesmo modo que se conhece agindo. $\mathrm{O}$ conhecimento humano em seu conjunto integra-se na dupla e infinita tarefa do homem de transformar a natureza exterior e sua própria natureza. (VÁZQUEZ, 1977, p. 192). 
As situações-problema da escola, como escasso tempo e poucas possibilidades de reflexão junto aos professores, são mapeadas; porém, na busca por qualificar o processo de assessoria, esses elementos, passam a ser problematizados como sendo fatores determinantes para a reprodução da cotidianidade.

Passo a compreender que, num círculo vicioso, enquanto professora assessora, minha atuação se dava a partir de estruturas alienantes quando, pelas condições dadas no cotidiano escolar, intensifica-se os limites de minha atuação. Constato que minha práxis limitava-se a reprodução.

Frente ao contexto apresentado, algumas inquietações se destacavam acerca dos desdobramentos advindos dos alunos com dificuldades de aprendizagem e das demandas dos alunos com deficiência. Sobre os alunos com tais características, questionava-se como estes estabeleciam relação com o conhecimento e, quanto aos seus professores, buscava-se compreender quais impactos o diagnóstico poderia causar frente ao processo de ensino.

Nesse percurso reflexivo, recoloca-se que diante das múltiplas inquietações e possibilidades de encaminhamentos, optou-se por observar o percurso educativo dos envolvidos no processo da educação inclusiva pois, segundo Vázquez (1977, p. 40), “a prática como fim da teoria exige uma relação consciente da necessidade prática que deve ser realizada com a ajuda da teoria".

Nesta perspectiva, sabe-se que esse movimento exigia da assessoria conhecimento e condições de análise da totalidade do que se manifestava na escola. Tal processo é ressaltado a partir das relações estabelecidas entre os sujeitos envolvidos no contexto educacional quando as ações de gestão de política pública e as ações pedagógicas da PAEI, da equipe diretiva (diretora e vice) e da professora se imbricam frente ao atendimento que direcionam aos alunos. Dessa forma, a gestão de política pública é representada no círculo central, uma vez que entende-se que toda ação pedagógica dos demais sujeitos advém das condições dadas a estes pela gestão pública.

A partir da imagem abaixo se tem a intenção de tornar mais evidente as relações entre as diferentes instâncias do objeto da pesquisa. 


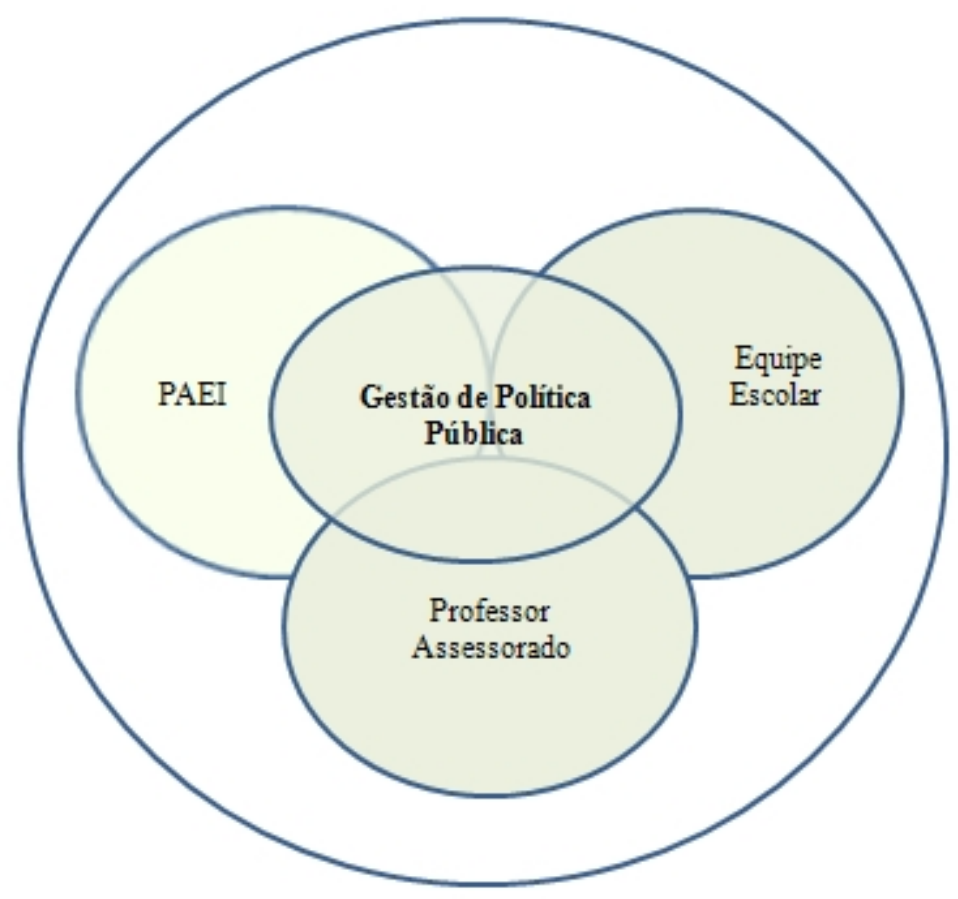

Quadro 01: Síntese do movimento dos eixos de análise no contexto educacional inclusivo

Ressalta-se que as dimensões da ação pedagógica do PAEI devem ser consideradas em cada um dos eixos representados acima, entendendo que os mesmos não podem ser compreendidos isoladamente pois, em conformidade com Asbahr, é necessária:

uma compreensão da realidade escolar para além das produções individuais dos sujeitos, buscando analisar como as práticas e relações escolares são produzidas em um contexto que abarca desde as relações engendradas na própria escola até as relações da escola com as políticas públicas educacionais vigente. (ASBHAR, 2011, p. 109)

Dessa forma, coloca-se que os eixos devem ser analisados em sua inter-relação pois, na busca por problematizar a escola que se intitula inclusiva, sabe-se que em sua essência excludente é possível encontrar uma variedade de manifestações entre todos os envolvidos no processo. Junto à equipe escolar e professor assessorado, surgem sentimentos de estranheza, inquietações, negação, medos e desconfortos. Por parte da gestão de política pública, rupturas e movimento de descontinuidade. Enfim, sabe-se que esses elementos influenciam diretamente na ação pedagógica.

Tais manifestações do cotidiano escolar conduziram a pesquisa a focar essas dimensões sinalizando que num contexto conturbado em que o volume de ações da assessoria distanciava a todos das possibilidades de reflexão, entendia-se, a partir de Souza (2000, p. 
127), a necessidade de "reconstruir a vida cotidiana da escola tendo como referentes necessários os sujeitos que a constituem [...]”, portanto, fazia-se necessário articular espaços para problematização do processo.

Neste contexto, a dialética inclusão/exclusão permeia esta pesquisa, sinalizando a forma como a atual sociedade se organiza, refletindo, assim, o processo histórico pautado nas ações alienadas produzidas histórica e coletivamente no cotidiano, pois, segundo Patto (2000, p. 65), "a desigualdade e a exclusão são justificadas cientificamente [...] através de explicações que ignoram a sua dimensão política e se esgotam no plano das diferenças individuais de capacidade".

Portanto, estar diretamente envolvida com o movimento da escola, buscando coletar dados, analisar e interpretar a dinâmica estabelecida pelos sujeitos ativos que nela se manifestavam, remete declarar que esta investigação se dá na realidade concreta do cotidiano escolar.

Propondo a problematização do cotidiano da escola, em todos os encontros com a professora que faz parte da pesquisa (a partir dos relatos, registros e observações), busca-se refletir sobre a ação pedagógica para além das evidências do imediato, que se objetiva a partir das queixas sobre as dificuldades de aprendizagem e das condutas dos alunos.

Desse modo, avalia-se que no início de 2011, no exercício da função de professora assessora, realizava inúmeras ações de maneira desarticulada, sem que houvesse um planejamento que indicasse uma finalidade clara; idealizada pela assessoria. No entanto, a partir das reflexões desencadeadas no coletivo do grupo de estudos, passa-se a perceber e a defender a necessidade de compreensão sobre a ação pedagógica de todos os envolvidos no processo da educação inclusiva, tendo como objetivo a superação frente ao exercício da assessoria.

Esse processo é apresentado, pois se entende que, de um movimento a outro, o exercício da ação pedagógica se dá inicialmente, a nível reiterativo para, na sequência, transformar-se. Este movimento de transformação será apresentado a seguir pois, durante a coleta dos dados da pesquisa, busca-se compreender as relações estabelecidas quando se problematiza na historicidade do processo o que acontece na escola a partir dos princípios políticos e culturais que norteiam a prática coletiva educacional inclusiva.

\subsection{Etapa da Ação Pedagógica Reiterativa}


No movimento da realidade concreta da educação inclusiva, constata-se que a forma de atuação da assessoria do $\mathrm{CADE}$, em geral, não possibilitava a criação de mecanismos que colaborassem com o processo de transformação dos professores que eram acompanhados pelo professor assessor. A reprodução do movimento caótico da assessoria não permitia a criação de uma nova realidade. Sobre esse aspecto, Vásquez afirma que:

[...] a práxis imitativa ou reinterativa tem por base uma práxis criadora já existente, da qual toma a lei que a rege. É uma práxis de segunda mão que não produz uma nova realidade; não produz uma mudança qualitativa na realidade presente não transforma criadoramente, ainda que contribua para ampliar a área do já criado e, portanto, para multiplicar quantitativamente uma mudança já produzida. Não cria, não faz emergir uma nova realidade humana, e nisso reside sua limitação e sua inferioridade em relação à práxis criadora. (VÁSQUEZ, 1977, p. 258)

Como já colocado anteriormente, a partir de Vázquez (1977), entende-se que o grau de consciência que o sujeito revela no percurso da ação pedagógica, não deixa de refletir no produto de sua atividade. Dessa forma, convém retomar que enquanto professora assessora de educação inclusiva, os registros sobre o percurso educativo do aluno, inicialmente se davam com a intenção de cumprir a normativa. De certa forma, este registro fornecia dados aos profissionais das escolas sobre as demandas do aluno acompanhado, no entanto, não colocava os profissionais em movimento junto ao processo educacional.

Frente ao exercício de uma práxis reiterativa, o registro sobre as ações desencadeadas pela assessoria se dava de maneira livre, quando nos espaços em branco cabia posicionar desde as necessidades dos alunos, suas manifestações e avanços, como somente o registro da visita à escola. Este movimento em torno do registro dependia de como cada professor assessor conceituava esse instrumento.

Além das concepções diferenciadas, outro agravante era o tempo, afinal, como já colocado, cada professor assessor era responsável por uma quantia de três a cinco unidades escolares, dependendo do número de matrículas de aluno com deficiência, sendo que, raramente conseguia estar uma vez por semana em cada uma das unidades.

A cada tentativa de encontro com os profissionais das escolas, percebia-se que todos estavam cada vez mais absorvidos pela dinâmica do cotidiano escolar.

As queixas, fragilidades e estranhezas por parte dos profissionais que atuavam junto aos alunos com deficiência evidenciavam que o movimento da assessoria, enquanto ação pedagógica, limitava-se a reproduzir ações ao nível da práxis imitativa pois, segundo Vásquez: 
$\mathrm{Na}$ práxis imitativa, estreita-se o campo do imprevisível. O ideal permanece imutável, pois já se sabe por antecedência, antes da própria realização, o que se quer fazer e como fazer. A lei que rege o processo prático já existe, de forma acabada, anteriormente a esse processo e ao produto no qual ele culmina. (VÁZQUEZ, 1977, p. 258)

Diante de um processo prático já existente, enquanto professora assessora seguia apenas reproduzindo o que estava instituído: preencher fichas, analisar e acompanhar planejamentos pedagógicos, atender alunos, professores, diretores, pais, buscar informações sobre tratamentos clínicos e terapêuticos, acompanhar alunos com deficiência em diferentes espaços das escolas e em salas de recursos multifuncionais, orientar e compartilhar informações com as agentes sociais de inclusão, enfim, reproduzir a realidade da assessoria em diferentes unidades escolares sem reflexão sobre o processo.

Este processo alienado no exercício da função de assessoria pode ser melhor compreendido quando Bernardes (2009, p. 238) coloca que "tal realidade descaracteriza a atividade pedagógica como uma particularidade da práxis que visa ao processo de transformação da própria sociedade por meio da transformação dos indivíduos[...]”. Nesse alinhamento reflexivo, entende-se que diante das dificuldades encontradas nas escolas, as ações enquanto professora assessora apresentavam-se fragmentadas, distanciando-me cada vez mais da percepção da função social que exercia.

Sobre este aspecto, Vázquez (1977, p. 247) colabora afirmando que "a repetição se justifica enquanto a própria vida não reclama uma nova criação [...] O homem não vive num constante estado criador. Ele só cria por necessidade. Repete, portanto, enquanto não se vê obrigado a criar".

Diante das evidências, entendia-se que não bastava apenas descrever a realidade quando a reprodução desse formato de trabalho se deu até o momento em que surge uma nova necessidade: buscar mecanismos que conduzissem ao processo de superação, pois o movimento caótico das escolas e suas demandas apontavam que o exercício enquanto professora assessora cada vez mais se limitava à reprodução de uma práxis reiterativa. Segundo Vázquez (1977, p. 246), “a prática reiterativa tem parentesco com a espontânea [...] Mas estes vínculos não são imutáveis; eles se dão no contexto de uma práxis total, determinada por sua vez por um tipo peculiar de relações sociais".

Frente às relações estabelecidas com os profissionais da educação, suas demandas e necessidades, entende-se que as possibilidades existentes nas escolas, exigiam da assessoria uma posição realista, portanto, conduziram-me a organização de uma nova ação pedagógica frente ao exercício da função de assessora. 
Nesse momento, a partir da elaboração do nível de consciência sobre a função que exercia, a assessoria se dá, entendendo da importância de promover reflexões que conduzissem o professor à percepção do seu papel social frente aos alunos, independente das características, afinal, aquele, não era professor somente do aluno com deficiência ou com dificuldades de aprendizagem, era professor de todos que se apresentavam a ele.

$\mathrm{Na}$ intencionalidade de clarificar e qualificar o processo educativo, a cada encontro intensifica-se a busca por espaços de reflexão e de estudo entendendo que, para colaborar com o processo, só seria possível encontrar caminhos para superação a partir de reflexões sobre a função social da escola e do professor, pois, segundo Saviani:

Do ponto de vista da educação o que, significa promover o homem? Significa tornar o homem cada vez mais capaz de conhecer os elementos de sua situação para intervir nela transformando-a no sentido de uma ampliação da liberdade, da comunicação e colaboração entre os homens. [...] Esta distância entre o que é e o que deve ser constitui o próprio espaço vital da existência humana; com efeito, a coincidência total entre o ser e o dever-ser, bem como a impossibilidade total dessa coincidência seriam igualmente fatais para o homem. (SAVIANI, 1982, p. 41)

Diante da percepção da necessidade de emancipação dos sujeitos da escola que fazia parte desta pesquisa, intensifica-se a busca por reflexões e ações que pudessem qualificar o processo da práxis pedagógica quando, em conformidade com Saviani, entende-se que, para haver a promoção do homem, este precisa estar capacitado a entender os elementos de sua história para que, a partir do conhecimento, possa intervir nela, transformando-a.

Partindo da perspectiva de necessidade da busca por transformação, e na objetivação de contribuir para a emancipação dos sujeitos participantes desta pesquisa, a assessoria do $\mathrm{CADE}$ se propõe à construção de uma ação pedagógica reelaborada, de forma a se distanciar da reprodução do que se encontrava instituído na escola.

\subsubsection{Etapa da Ação Pedagógica Reelaborada}

Sabe-se que, para objetivar o fim almejado, é preciso condições adequadas, mas, se elas não existem, entende-se que estas precisam ser planejadas, pois não basta somente interpretar e descrever a realidade.

Nessa perspectiva, a necessidade de reelaborar a ação pedagógica enquanto professora assessora intensifica-se pois, segundo Vásquez: 


\begin{abstract}
A prática exige um constante vaivém de um plano a outro, que só pode assegurar-se se a consciência se mostra activa no decurso de todo o processo prático. Resulta assim, que se é certo que a actividade prática sobretudo como práxis individual, é inseparável dos fins que a consciência traça, estes fins não se apresentam como produtos acabados, mas num processo que só atinge o seu termo quando o fim ou resultado ideal, depois de sofrer as modificações exigidas pelo processo prático, é já um produto real. Desse modo, ajustando-se mutuamente uma a outra e avançando por caminhos distintos até o final do processo de hipótese em hipótese - a actividade teórica-, e de experiência em experiência - a actividade prática -, ambas convergem num produto objetivo ou resultado ideal. (VÁZQUEZ, 1977, p. 48)
\end{abstract}

Num exercício de busca pela unidade do teórico e do prático na atividade da assessoria, entende-se ser somente a partir da elaboração da consciência que os sujeitos podem estabelecer relação com o meio, visando transformação. Nesta perspectiva de superação e de transformação, entende-se a necessidade de reelaborar a práxis de forma a qualificar todo o processo de assessoria, sendo que uma das etapas da pesquisa consistia em reorganizar a agenda para encontros com os professores de forma a atender a demanda com periodicidade e qualidade.

Dessa forma, em 2011, atuando ao mesmo tempo como professora assessora de educação inclusiva e enquanto pesquisadora, percebe-se a necessidade de direcionar maior atenção à escola participante desta pesquisa. Após distribuição da demanda de trabalho, continuava atendendo todas as unidades de ensino, no entanto, direcionava mais tempo à professora integrante da pesquisa, na busca por analisar sua ação pedagógica e os desdobramentos desta a partir da relação estabelecida com a assessoria a partir das condições existentes para o exercício da mesma. Dessa maneira, no período em que a pesquisa acontece e de acordo com as possibilidades, semanal ou quinzenalmente, era agendado um encontro com a professora que manifestara interesse em participar dos estudos e desta forma, a professora, uma aluna com deficiência intelectual e um com quadro de dificuldades de aprendizagem, passaram a ser acompanhados sistematicamente. Nesses encontros, diante do processo pedagógico as manifestações da professora e do aluno eram acompanhadas e analisadas a partir das produções e das relações estabelecidas entre si, possibilitando assim o registro dos dados da pesquisa.

Entendia-se a importância de colocar a professora em contato com os fundamentos teóricos que sustentavam esta pesquisa. Dessa forma, justificando a importância dos mesmos para a compreensão da função da escola e do professor, coloca-se para a professora que outra etapa planejada referia-se ao processo de estudos.

Sendo necessário aprofundamento nas análises sobre as práticas pedagógicas e sobre as ações que envolviam a aprendizagem escolar, após a professora manifestar interesse, 
inicia-se a "tentativa" de estudos. É necessário explicitar que mesmo interessada, a mesma queixava-se do pouco tempo disponível, fato que comprometeu diretamente esse propósito.

A organização, elaboração e articulação do planejamento da assessoria e da professora, considerada outra etapa importante desta pesquisa, tratava-se da busca por tempo e espaço adequados para a realização da mesma.

Durante a dinâmica estabelecida para a realização dessa demanda, ficou estipulado que o planejamento semanal da assessoria e da professora seria elaborado e discutido ao longo dos encontros. A professora integrada a esta pesquisa, passa a receber orientações e lhe é solicitado que passe a registrar em seu semanário, dúvidas, impressões, inquietações, idéias e dados das necessidades e conquistas sobre seus alunos. Entendia-se que o tempo para o cumprimento de tal tarefa era escasso, mas procuravam-se alternativas para solucionar esta questão. Todas as semanas, em diferentes espaços (parque, local da merenda, pátio, quadra, corredores da escola, porta de sala de aula, biblioteca e salas de informática ou outros) tentava-se problematizar as ações pedagógicas planejadas. É aspecto importante colocar que os registros nos semanários nem sempre eram realizados. No entanto, em todos os encontros, a professora, após queixar-se da falta de tempo para realizar os registros, relatava suas iniciativas e tentativa de organização diante dessa demanda pedagógica.

Outra etapa reelaborada desta pesquisa refere-se ao instrumento de registro do planejamento semanal do professor assessor de educação inclusiva. Esse instrumento foi problematizado ao longo da pesquisa e passou por transformações.

Inicialmente, o registro se dava de maneira livre, sem tópicos que envolvessem a todos que atuavam diretamente com o aluno com deficiência como segue?:

\section{Prefeitura de \\ Santo André}

Secretaria de Educação e Formação Profissional

CADE - Centro de Atenção ao Desenvolvimento educacional

REGISTROS: 2011 ALUNO (A):

Conversa e orientação à professora indicando que a aluna precisa ser estimulada a perceber e fazer uso das normas durante utilização do caderno;

É necessário envolver a família enviando atividades para que a mãe possa realizar junto com a filha;

É importante antecipar informações, por exemplo, enviando textos para serem lidos antes de serem utilizados na classe;

Figura 1: Registro das ações pedagógicas realizado pela PAEI.

No entanto, clarifica-se que as modificações no registro do professor assessor é uma interferência planejada já na tentativa de criar condições para que as mudanças

\footnotetext{
${ }^{9}$ O registro foi digitado de acordo com o original evitando-se o nome dos sujeitos: professora e aluno.
} 
qualitativas pudessem ocorrer. Dessa forma, em busca de respostas, e na medida em que a práxis do professor assessor entra também no foco da pesquisa, o registro enquanto pesquisadora e professora assessora de educação inclusiva passa a abordar os seguintes itens:

a. Sujeitos: professor/ professor assessor de educação inclusiva/ aluno

b. Descrição da necessidade

c. Ação encaminhada pela assessora do CADE

d. Ação a ser realizada pela professora

e. Retorno das ações realizadas pela professora

f. Descrição da nova demanda

Convém esclarecer que pelo pouco tempo disponível, entende-se que esse instrumento, contendo todos esses elementos, amplia a complexidade do trabalho frente ao registro; no entanto, o mesmo foi utilizado por mim, enquanto professora assessora na função de pesquisadora, somente na unidade participante da pesquisa. Nas demais escolas onde atuava, somente enquanto professora assessora opto por manter o mesmo formato de registro utilizado pelas demais profissionais do CADE. Essa opção está vinculada ao fato de não haver condições de executar esse procedimento em todas as unidades devido à grande quantidade de alunos sendo acompanhados pela assessoria.

É importante colocar que o planejamento do professor assessor foi redirecionado e redefinido de acordo com as necessidades que foram se apresentando ao longo da pesquisa. $\mathrm{O}$ planejamento deixa de ser um mero instrumento de registro enquanto professora assessora realizava na escola, passando a se tornar um instrumento de retomada das ações junto a professora e equipe escolar.

A necessidade de reelaboração da ação pedagógica conduziu, então, a reorganização do processo, e o planejamento da assessoria passa a incluir tópicos que envolvia a todos de forma a possibilitar reflexões sobre as demandas, necessidades, desafios e perspectivas educacionais.

No instrumento de planejamento e registro enquanto pesquisadora e professora assessora, os tópicos faziam referência aos sujeitos da ação pedagógica. Dessa forma, os dados da pesquisa são coletados a partir desse instrumento, contendo manifestações da ação pedagógica de todos os envolvidos no processo: professora acompanhada, professora assessora, agente social de inclusão e equipe diretiva. 
Vale destacar que diante dos tópicos descrição da necessidade, ação encaminhada pela assessora do CADE e retorno das ações realizadas, o planejamento tinha como objetivo envolver os sujeitos do processo, quando na retomada da práxis pedagógica as reflexões sobre as demandas, necessidades e perspectivas educacionais estariam em movimento, pois todos problematizariam sua função social. Numa dinâmica envolvendo planejamento, encaminhamentos e replanejamento, busca-se de maneira articulada atender não só às necessidades apresentadas pelos alunos, mas tinha-se a intenção de conduzir ações que atendessem as necessidades e expectativas apresentadas pela professora sobre o exercício da ação educativa no coletivo da sala de aula.

Partindo desse novo formato de acompanhamento e registro, tinha-se o objetivo de que os encontros com a professora integrada à pesquisa e demais profissionais da escola, se intensificassem para que juntos, pudessem se perceber partícipes do processo.

Além dos itens constados no planejamento e registro da assessoria, outros dados observados ao longo dos encontros foram registrados, e na medida em que se ampliaram, foram acrescidos de mais informações, impressões, questionamento e hipóteses levantadas pela pesquisadora a partir da análise das condições e atuação da professora frente ao desenvolvimento dos seus alunos com deficiência intelectual e dificuldades de aprendizagem e sobre as condições para o exercício da assessoria.

É válido declarar que se entende que o processo de transformação e ressignificação do instrumento de registro é considerado como sendo o primeiro momento de análise dos dados que ocorre ainda durante a pesquisa de campo.

Em razão deste processo, procurando documentar o pensamento através dos registros, durante a realização das leituras dos elementos que se apresentaram à escola e somando-se às observações e análises do percurso educativo da professora e da professora assessora, os dados foram organizados e serão apresentados na sequência.

\subsection{Procedimentos analíticos}

Em conformidade com Oliveira (1996, p. 27), entende-se que esta pesquisa deve apresentar seu movimento considerando "o cotidiano escolar desde os seus pressupostos até suas implicações teórico práticas”. 
Dessa forma, apresentam-se os dados da pesquisa com o objetivo de mostrar o movimento da mesma saindo dos limites do imediato na busca pela essência dos fenômenos pesquisados, sendo eles os limites e as possibilidades dados pela política pública local para o exercício da função do professor e do professor assessor diante da educação inclusiva.

Entende-se que a primeira parte da organização dos dados se caracteriza como uma descrição empírica quando esta se baseou nas seguintes categorias descritivas:

- o cenário de investigação, sendo eles: a escola e a sala integrada a pesquisa;

- a descrição empírica dos dados, sendo: a ação pedagógica da professora assessora

Na continuidade da pesquisa, busca-se superar a descrição empírica, pois, como se sabe, descrever é apenas a primeira parte a ser realizada pelo pesquisador na busca pela compreensão da realidade. Torna-se necessário, portanto, a construção de categorias de análise que indiquem a possibilidade de superação do concreto caótico, pois, segundo Meira (2000, p. 40), "é preciso situar os dados no quadro histórico articulando os dois momentos fundamentais da atividade de conhecer: o momento da aparência, trazido pelos dados, e o da essência, construído através do pensamento teórico". Dessa forma, busca-se alinhar os eixos e as categorias de análise de forma a indicar os limites e as possibilidades advindas de todos os segmentos envolvidos na pesquisa, sendo eles: a gestão de política pública, a equipe escolar, a professora assessora de educação inclusiva e a professora assessorada como segue abaixo.

$\mathrm{Na}$ busca pela construção das categorias de análise, a partir dos eixos gestão de política pública, PAEI, escola e professor assessorado e também frente aos dados levantados, no processo de construção das mesmas desencadeiam-se alguns questionamentos. Frente aos eixos de análise, pergunta-se: quais desdobramentos devem ser considerados e analisados para que a realidade desejada possa ser objetivada? Frente aos dados, o que precisa ser destacado de forma que seja superado a análise descritiva do processo? Como compreender o objeto da pesquisa para além da aparência de forma a pinçar dos dados elementos que indicassem os limites, as possibilidades e as necessidades para a superação do problema?

A partir da condução teórica e dos questionamentos, elaboram-se as categorias de análise entendendo que, no processo, as mesmas possibilitariam apreender e indicar os limites e as possibilidades de atuação dos sujeitos frente ao fenômeno da educação inclusiva. Tais categorias passam a nortear a análise dos dados, sendo elas: 
- categoria da governança do tempo e do espaço

- categoria da imediaticidade das necessidades na realidade concreta

- categoria da dimensão tarefeira na ação pedagógica

Entende-se que tal organização, a partir das categorias de análise, permite maior compreensão acerca do movimento da pesquisa, e entende-se também que na busca pela análise da realidade por meio do levantamento dos dados e do processo do envolvimento na realidade concreta, torna-se necessário o retorno à mesma pois segundo Asbhar (2011, p. 118), "após esse processo de abstração, ou análise da realidade por meio das abstrações, torna-se necessário voltar à realidade para explicá-la".

Sendo submetida à gestão de política pública, entende-se que a categoria da governança do tempo e do espaço incide diretamente sobre a categoria da imediaticidade das necessidades na realidade concreta uma vez que toda ação pedagógica desencadeia-se dentro dos limites e das possibilidades advindas das condições acerca do tempo destinado para a realização de tais ações no cotidiano da escola.

Nessa condução de análise, entende-se que as categorias da governança do tempo e do espaço e da imediaticidade das necessidades na realidade concreta reduzem a atuação de todos os envolvidos no processo, conduzindo assim os sujeitos da escola a atuarem na lógica da categoria da dimensão tarefeira na ação pedagógica.

Coloca-se que as três categorias estão diretamente relacionadas no entanto indicase que as mesmas foram individualmente problematizadas com a intenção de otimizar a explicitação da análise dos dados pois entende-se ser necessário a superação da descrição empírica.

A imagem a seguir visa retratar as relações estabelecidas entre as categorias de análise e os envolvidos no processo educacional, sendo eles a professora, a professora assessora de educação inclusiva e os sujeitos da equipe escolar (diretor, vice, assistente pedagógico e agente social de inclusão). 


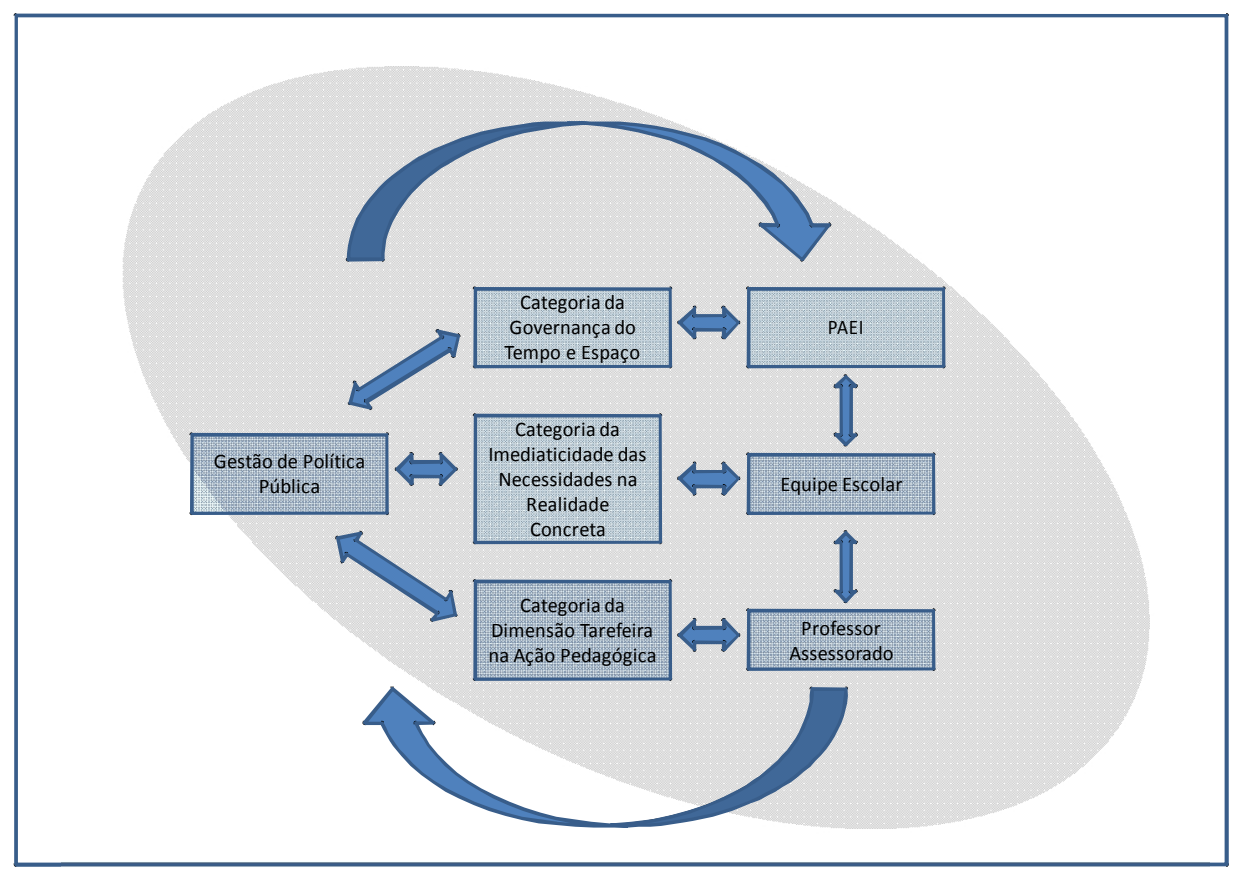

Quadro 02: Movimento de Análise na Realidade Concreta

Ressalta-se a partir do esquema que as três categorias apresentam elementos que são indissociados e, sendo assim, se apresentam conjuntamente no contexto analisado.

A partir destes elementos, retorna-se à realidade concreta da educação inclusiva compreendendo, a partir da condução teórica, ser necessário a busca pela totalidade de determinações e relações do contexto analisado.

\subsubsection{Categoria da governança do tempo e do espaço}

A categoria da Governança do tempo e do espaço, entendida ser movimentada pela gestão da política pública local, é analisada a partir das condições organizacionais e estruturais para o exercício da assessoria uma vez que em conformidade com o primeiro capítulo, entende-se que esta influencia diretamente o cotidiano escolar.

Para análise dessa categoria, é abordada a agenda mensal e as pautas das reuniões realizadas com a equipe do $\mathrm{CADE}$, entendendo que ambas indicam os limites e as possibilidades para as realizações das ações da professora assessora a partir do que idealizava a gestão da política pública local durante o período da realização da pesquisa em questão.

Abaixo apresenta-se uma agenda mensal onde indicam-se os encontros realizados com a equipe de professores assessores e destes com os sujeitos envolvidos no processo 
educacional inclusivo. Destaca-se de acordo com esta agenda, que a equipe de professores assessores teve a oportunidade de encontrar-se nos dias 02,14 e 28 de fevereiro.

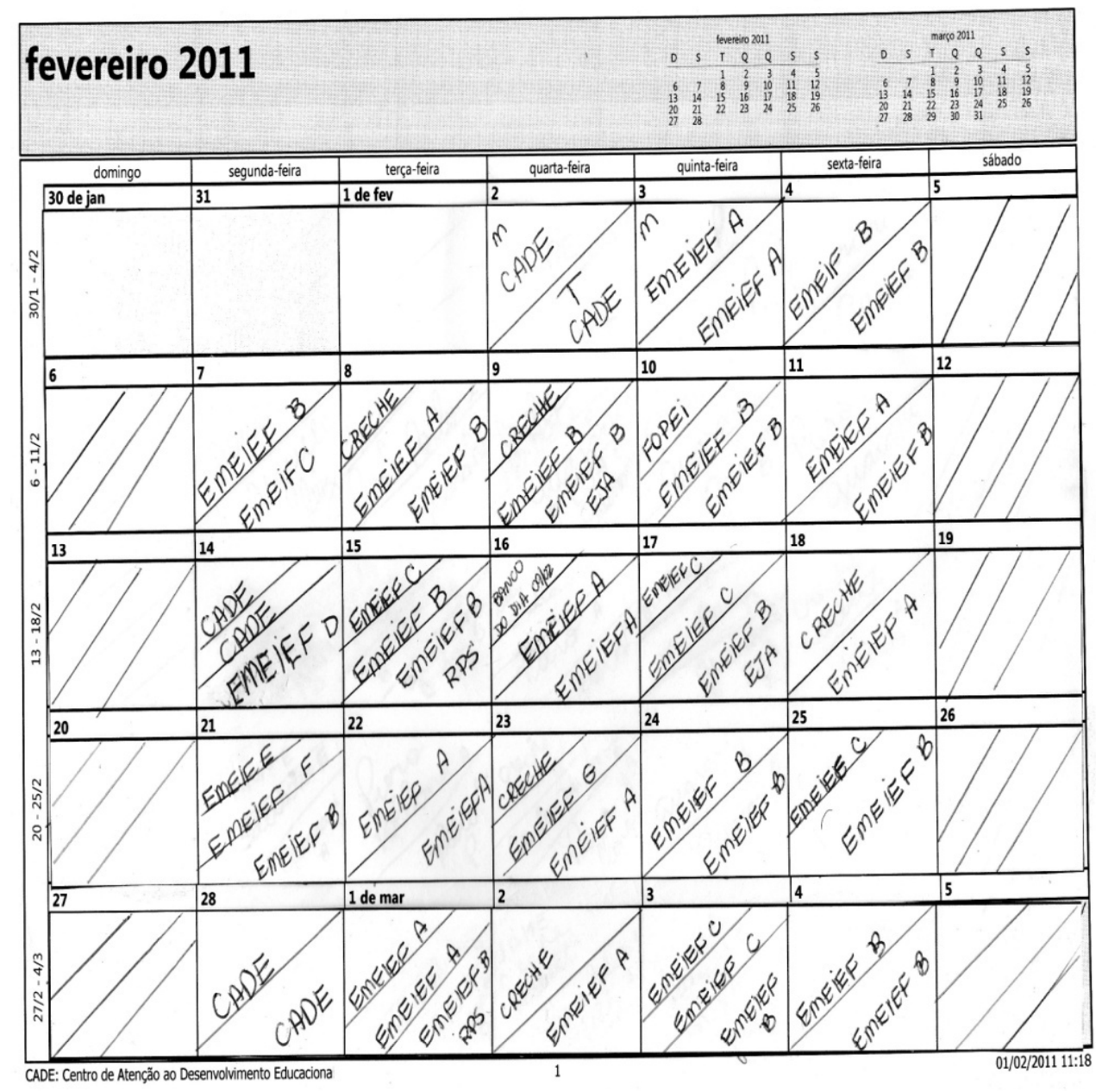

Figura 02: Agenda mensal da PAEI.

O que chama a atenção nessa agenda é o fato de que a mesma indica que a professora assessora realizou naquele mês um total de 39 encontros com distintas equipes em diferentes dias, turnos e locais sendo:

- Na EMEIEF A um total de 9 encontros (indica-se que nesta unidade acontece a pesquisa)

- Na EMEIEF B: 13 encontros

- Na EMEIEF C: 5 encontros

- Na CRECHE: 5 encontros

- Outros espaços ( Sala de Recursos e FOPEI) 4 encontros

- Reunião da equipe do CADE: 3 encontros 
Nessa condução da análise coloca-se que um limite a partir da agenda mensal apresenta-se quando esta prioriza a atuação do professor assessor em campo, ou seja, indica que na concepção da gestão de política pública, estar em contato com as escolas era prioridade, pois, estando no cotidiano, a assessoria poderia emergencialmente atender às demandas advindas das necessidades dos alunos com deficiência. Dessa forma, os encontros da equipe do CADE passam a ser semanal ou quinzenal, distanciando assim a possibilidade de estudos e compartilhamento de ideias.

Essa organização inviabiliza o avanço das percepções do grupo frente ao processo educacional inclusivo, pois, diante do reduzido número de reuniões, as discussões tornaram-se escassas e sempre atravessadas por queixas da própria equipe de assessores sobre a crescente demanda, quando então, estes eram conduzidos a pensarem as deficiências e seus desdobramentos a partir de aspectos biologizantes.

Alinhada ao movimento instituído percebe-se, a partir das pautas apresentadas nas reuniões da equipe, que as ações se dão de maneira a conduzir o grupo ao cumprimento de inúmeras ações organizacionais, distanciando a todos da possibilidade de reflexão sobre o processo educacional inclusivo na sua totalidade.

A pauta a seguir apresenta ações que são desenvolvidas nos encontros formativos entre os professores assessores e equipe de coordenação do CADE:

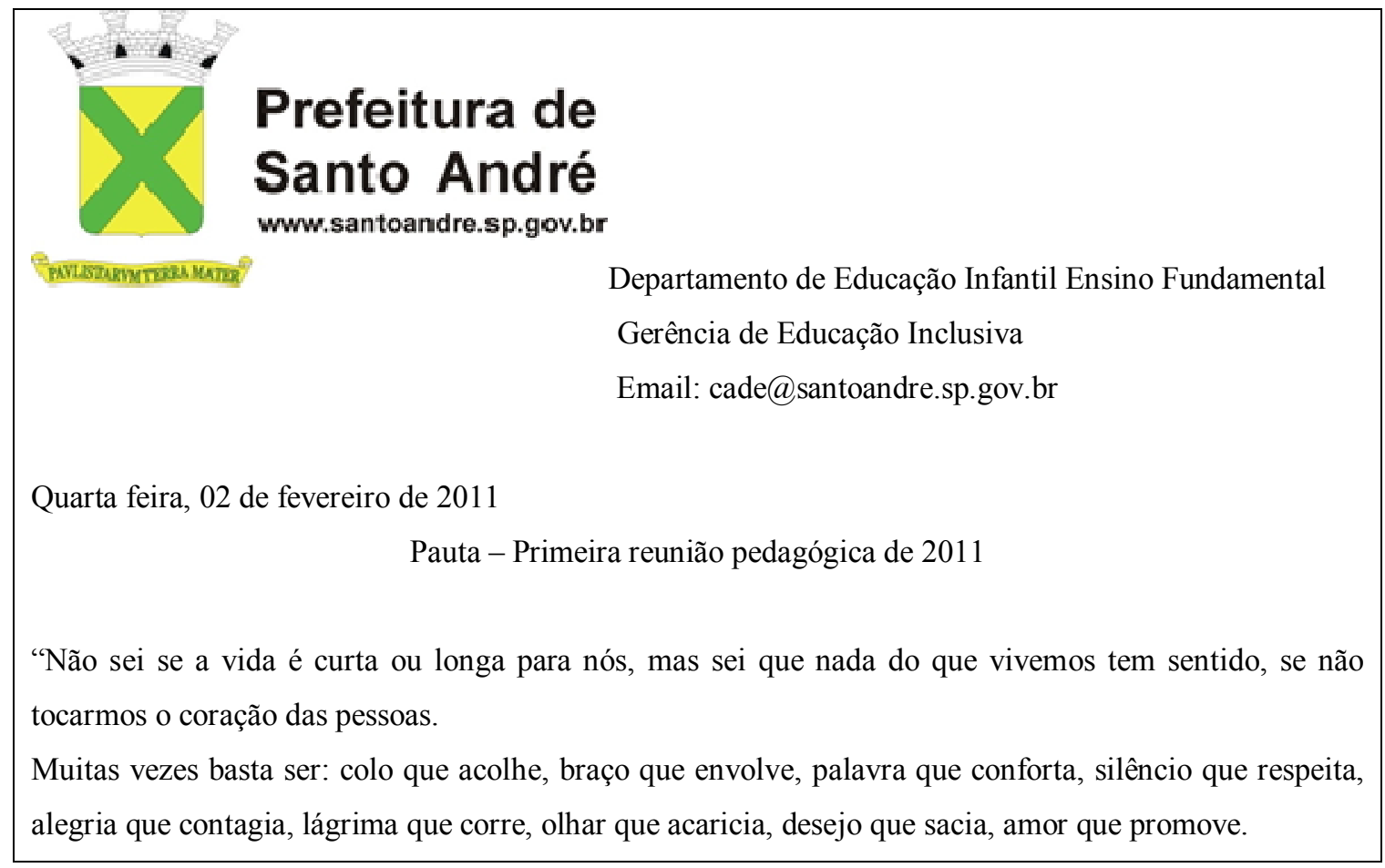


E isso não é coisa de outro mundo, é o que dá sentido à vida. É o que faz com que ela não seja nem curta, nem longa demais, mas que seja intensa, verdadeira, pura enquanto durar. Feliz aquele que transfere o que sabe e aprende o que ensina". Cora Coralina

\section{Manhã}

- Reorganização Unidades escolares;

- 2011: Documentação para registro;

- Formações realizadas em Janeiro;

- Ampliação ASI e nova organização/formação;

- Organização de demandas, matrículas, transporte;

- Transporte- Leitura do decreto N 16. 107, de 25 de novembro de 2010;

- Projeto Político Pedagógico 2011 - organização sala de recurso, plano de trabalho da PAEI; material pedagógico para compras, organização de ASI;

- Projeto Formadores do Saber - material didático

- Demandas PAEI

- Devolutivas individuais PAEIs ( 2 semana de fevereiro)

- Parceria Fundação Medicina ABC

Tarde

- Texto de introdução à sondagem;

- Em grupos analisar a proposta de sondagem e acrescentar elementos se necessário;

- Plano de trabalho 2011

Bom trabalho

Coordenação CADE

Figura 03: Pauta de reunião da equipe do CADE

Dessa pauta destaca-se o fato da mesma apresentar uma significativa quantidade de ações sendo desenvolvidas no âmbito da organização das demandas da assessoria. Notase que mesmo sendo uma pauta referente ao início de um ano letivo, não há indicações de planejamento ou levantamento acerca das expectativas e das necessidades formativas para a equipe de professoras assessoras. Ao contrário, na pauta indica que em Janeiro foram realizadas formações com as agentes sociais de inclusão e tal fato merece destaque, pois as formações com esta equipe de profissionais (ASI) deixam de ser realizadas pela equipe de professores assessores passando a serem realizadas pela equipe clínica e terapêutica da Fundação de Medicina do $\mathrm{ABC}$ (destaque à parceria com tal instituição na própria pauta). Não se descaracteriza a importância destas formações, no entanto coloca-se que ao distanciar a equipe de professores assessores desta demanda, acentua-se o distanciamento entre estes 
profissionais, ASI e professor assessor do CADE, que no cotidiano da educação inclusiva, precisam ampliar suas percepções acerca do desenvolvimento pedagógico dos alunos. Sobre esse movimento, busca-se reflexão em Tanamachi (2000, p. 79) quando declara que "os modelos tradicionais enfatizam ora aspectos psicológicos, ora pedagógicos, sem buscar analisá-los dialeticamente e a outros determinantes que constituem a realidade da educação escolar".

Como já anunciado, as formações do CADE ficam sob a responsabilidade da Fundação Santo André. Dessa forma, durante o segundo semestre de 2009 e nos anos de 2010 e 2011, em muitas oportunidades, a equipe do CADE passa a receber profissionais da área terapêutica, para discutirem as manifestações das dificuldades de aprendizagem a partir de temas como dislexia, TDAH (transtorno do déficit de atenção e hiperatividade), TDA (transtorno e déficit de atenção), TGD (transtorno global do desenvolvimento), problemas de fala e problemas emocionais como indicado nas pautas dos dias 02, 14 e 28 de fevereiro de 2011, quando as mesmas destacam a parceria da educação com a Fundação de Medicina do $\mathrm{ABC}$.

Tais pautas indicam que outro limite colocado se dá, pois, conduzidos pela organização da política pública local, os professores assessores são distanciados da possibilidade da reflexão sobre si mesmo enquanto sendo parte de uma instituição sociocultural, neste caso, a escola. Dessa forma, em conformidade com Patto (2005) compreende-se que a cultura escolar tem sido legitimada a partir dos processos de exclusão explicados pedagógica e socialmente uma vez que se conduz à especialização dos problemas de aprendizagens focadas no aluno.

Compreende-se, portanto, que de forma bem intencionada, porém equivocada, a equipe de professores assessores de educação inclusiva passa a buscar nas demais ciências como a psicologia, psiquiatria, fonoaudiologia, neurologia e outras, respostas para os desafios encontrados na escola sem problematizar a relação da pedagogia com seus sujeitos. Segundo Souza:

Os protagonistas da escola em condições sociais, culturais e materiais específicos realizam a existência cotidiana da escola singular e ao fazê-lo refletem todos os elementos formais e não formais do sistema relacionados com seu contexto social. $\mathrm{Na}$ experiência cotidiana dos sujeitos, transpor as portas da escola constitui ao mesmo tempo uma continuidade, pois apenas desloca âmbitos sociais contíguos e mantém a sua própria identidade [...]. (SOUZA, 2000, p. 127) 
Dessa maneira, diante de um quadro caótico, a assessoria se distancia da possibilidade de construção de um olhar crítico que permitisse identificar as finalidades históricas e sociais presentes na trajetória da educação escolar e seu contexto histórico social. Coloca-se que dentro dos limites, os encontros da equipe foram destinados pela política pública a transformarem-se em tempos e espaços organizacionais e formativos restritos e tarefeiros. Segue outra pauta que possibilita a identificação deste movimento.

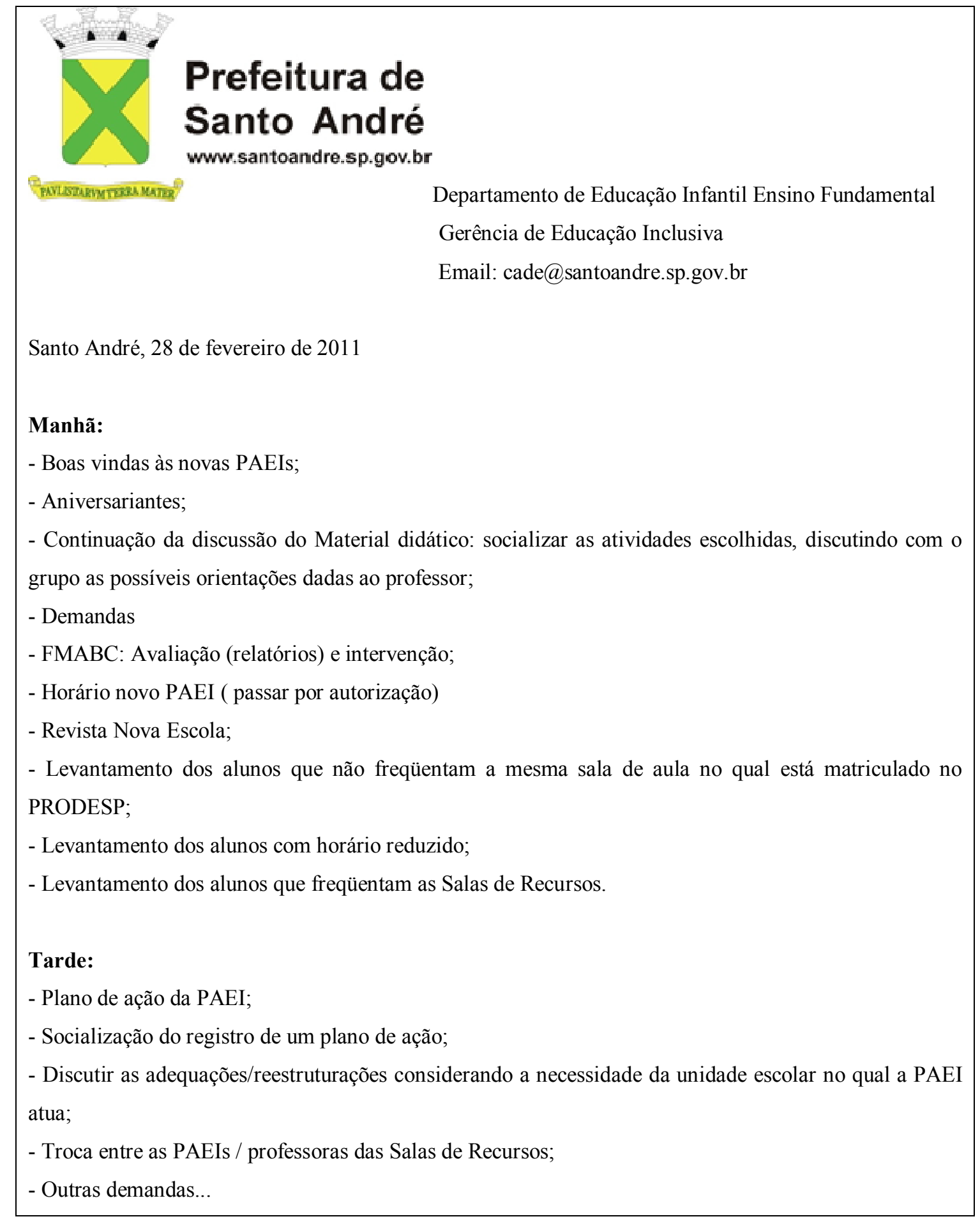

Figura 04: Pauta de reunião da equipe do CADE 
Tal análise é concebida uma vez que além dos poucos encontros entre a equipe, as pautas indicam que as formações se dão de forma restrita. No caso desse mês apresentado, destaca-se das mesmas os seguintes ítens:

- Em grupos analisar a proposta de sondagem e acrescentar elementos se necessário (pauta do dia 02 de fevereiro de 2011)

- Troca entre as PAEIs (pauta do dia 14 de fevereiro de 2011)

- Socialização do registro de um plano de ação (pauta do dia 28 de fevereiro de 2011)

Esses itens merecem destaque, pois os mesmos apontam ações formativas sendo realizadas pelo próprio grupo de PAEIs, sinalizando que as mesmas são conduzidas a agir reflexivamente sobre sua prática, compartilhando entre si saberes e experiências.

A partir de Facci (2004) entende-se que nesse movimento, o grupo é conduzido a realizar o compartilhamento de ideias a partir da perspectiva do professor reflexivo. Contribuindo, Pimenta (2002, p. 23) afirma haver "um oferecimento de treinamento para que o professor torne-se reflexivo".

$\mathrm{Na}$ perspectiva da pedagogia do professor reflexivo, referindo-se ao conceito do termo, Facci (2004, p. 66) coloca que “a massificação do termo distancia o profissional de uma reflexão no sentido marxiano, dificultando o engajamento dos docentes em práticas mais críticas, reduzindo-o a um fazer técnico, a um praticismo[...]". Portanto entende-se que a perspectiva do professor reflexivo indica que a prática e a reflexão devem guiar a ação pedagógica, sendo esse exercício uma contradição, pois tal perspectiva minimiza a condição do professor acerca da compreensão sobre sua função frente ao desenvolvimento da ação pedagógica.

Sobre esse aspecto, Serrão (2002) ao fazer a crítica a abordagem do "professor reflexivo" propõe pensar que atrelado ao exercício da função, há aspectos de ordem política e institucional que configuram o trabalho do professor e que, portanto, superar e romper com uma prática profissional envolvida numa trama social contraditória e complexa não depende exclusivamente de uma atitude reflexiva por si só, pois tal perspectiva propõe limites que a própria organização da sociedade capitalista impõe aos mesmos.

Dessa forma, a partir da gestão da política pública local, entende-se que este formato de formação destinada à equipe do $\mathrm{CADE}$, impõe mais um limite para o exercício da 
assessoria ao distanciar as PAEIs de uma formação didático - metodológica sustentada a partir de fundamentos políticos, filosóficos, históricos e sociais.

Nessa categoria de análise, na busca pela compreensão acerca das possibilidades dadas pela política pública local, nota-se que as pautas das reuniões evidenciam um significativo volume de ações sendo executadas nos poucos tempos e espaços destinados para as reuniões entre as professoras assessoras.

O volume de tarefas a serem realizadas pela equipe conduz a percepção da possibilidade da realização de inúmeras ações organizacionais bem como tentativas de formações focadas no sujeito baseando-se especificamente nas necessidades advindas daqueles que apresentavam necessidades educacionais especiais.

\subsubsection{A Imediaticidade das Necessidades na Realidade Concreta}

A categoria da Imediaticiadade das Necessidade na Realidade Concreta será analisada a partir dos dados levantados junto aos professores da escola e equipe diretiva escolar a partir dos registros das ações desenvolvidas nos encontros com a mesma. É necessário esclarecer que, compondo a equipe diretiva, atuavam em parceria uma diretora, uma vice diretora e uma assistente pedagógica.

Nessa categoria, um limite se apresenta ilustrado pelo fato de que ao adentrar a unidade de ensino para dar continuidade a uma ação já desencadeada na semana anterior (junto a professora assessorada), muitas vezes não conseguia fazê-lo, pois era solicitada a analisar inúmeros acontecimentos em parceira com a equipe diretiva ou com outros professores. Acontecimentos esses que muitas vezes não estavam relacionados aos alunos com deficiência, mas com alunos que apresentavam comportamentos inadequados ou que estavam apresentando quadro de dificuldades de aprendizagem. Tal fato é exemplificado com a apresentação do relato abaixo, cabendo esclarecer que este é um registro realizado no exercício da assessoria durante a pesquisa:

Manhã: conselho de ciclo na EMEIEF. Já na chegada a escola às 7 h30 fui recebida pela diretora que sinalizou estar feliz com minha presença. Solicitou-me alguns minutos para conversar e relatou os últimos acontecimentos com alguns professores que tem causado a ela alguns desconfortos por conta de posturas inadequadas. Logo chegou um aluno encaminhado pela sua professora que segundo a diretora tem apresentado dificuldades de aprendizagem. Ela (diretora) solicitou-me que 
conversasse com o aluno que cabisbaixo relatou-me uma história triste sobre a morte do seu coelho. A assistente pedagógica me pede ajuda solicitando que encaminhasse $\mathrm{o}$ aluno para tratamento. $\mathrm{O}$ conselho de ciclo começa às 9 horas. Vários casos sobre os alunos com dificuldades de aprendizagem são relatados, todos imersos em muita angústia e evidenciando o problema sócio- econômico e cultural da clientela. Poucos são os encaminhamentos que se repetem aos do bimestre anterior: chamar família, encaminhar para terapeuta, solicitar apoio do CADE... e quanto às ações pedagógicas? Toda vez que se sugere uma reflexão sobre o processo de adequação de atividades ou até mesmo faz-se sugestões de possibilidades de intervenção, os professores dizem já ter realizado todas elas. Fica evidente que querem entender o que o aluno tem enquanto sujeito que não aprende. Tarde: [...] Participei do conselho no período da tarde onde os problemas apresentados pelos alunos do $5^{\circ}$ ano são muitos e em diferentes situações: comportamentos inadequados/dificuldades para ler/dificuldades para escrever e calcular entre outras demandas. Acompanhei tentando contribuir com as discussões até as $17 \mathrm{~h} 30$. A assistente pedagógica solicitou que eu retornasse para ajudá-la a encaminhar os alunos que foram citados por problemas emocionais.[...] Ela pediu-me ajuda afirmando estar muito preocupada. (PAEI, EMEIEF em 03/10/2011)

Nesses encontros com os sujeitos da escola, evidenciava-se o quanto os professores e a equipe diretiva careciam de momentos de estudos, reflexões e atenção, pois equivocadamente buscavam compreender o problema focado somente no aluno. Sobre este aspecto Patto colabora declarando que:

[...] ao fechar o foco numa criança e numa família descontextualizadas social, política e institucionalmente, realiza-se uma manobra eficientíssima que despolitiza o cotidiano e justifica as desigualdades produzidas pela estrutura social de classes, ao transformá-las em desigualdades pessoais de aptidão para aprender. (PATTO, 2005, p. 170)

Cabe colocar, que esse momento do cotidiano escolar é evidenciado visto se tratar do encontro de profissionais da educação, incluindo a assessoria, que, de maneira bem intencionada, porém equivocada busca compreender, o que o aluno tem quando produz os problemas de aprendizagem.

Coloca-se também que, sendo um local de trabalho coletivo, o conselho de ciclo enquanto espaço formativo, deixa de ser funcional na medida em que profissionais da educação, o utilizam prioritariamente para manifestar queixas sobre o fracasso escolar dos seus alunos. Atuando na imediaticidade das necessidades do cotidiano caótico, a equipe segue desconhecendo as verdadeiras causas das dificuldades de escolarização da maioria dos seus alunos. Sobre este aspecto Patto declara que:

[...] as raízes da insuficiência do ensino oferecido na maior parte das escolas públicas só podem ser alcançadas se não esquecermos que a escola é uma instituição social, que a sociedade que inclui é uma sociedade extremamente desigual e injusta e que a política educacional é um dos instrumentos de reprodução desse estado de coisas. (PATTO, 2005, p. 49) 
Dessa forma, outro limite no exercício da assessoria é indicado, pois se entende que tanto os professores dos alunos com deficiência ou com dificuldades de aprendizagem, quanto o professor assessor de educação inclusiva, a agente social de inclusão, enfim as equipes escolares, absorvidos pela demanda na imediaticidade dos conselhos de ciclo e de toda dinâmica da escola, sinalizam pouca clareza sobre a função social do lugar que ocupam. Fragilizados pelo sistema, seguem reproduzindo o cotidiano do fracasso escolar ao nível da ação pedagógica reiterativa.

Diante do exposto, entende-se que todos, tomados pelo volume de ações que surgem na imediaticidade do processo, são distanciados da possibilidade de análise crítica sobre os reais motivos do fracasso escolar, fato que contribui para o processo de exclusão daqueles tidos como "alunos de inclusão".

Mesmo diante da intenção da busca pela compreensão acerca do problema educacional e da tentativa de incluir os alunos que apresentam necessidades educacionais especiais, a equipe escolar, ASI (agente social de inclusão), os professores e o professor assessor não avançam em suas hipóteses. Segundo Machado (2000, p 150), “conseguir uma prática inclusiva implica ir contra a maré que o próprio sistema produz [...]", no entanto, percebe-se a partir dos dados que, impactados e atarefados diante da demanda educativa, os profíssionais da educação não conseguem problematizar e encaminhar um processo de organização de ensino didático e metodológico que possibilite condições adequadas para que haja aprendizagem dos alunos que apresentam necessidades educacionais especiais.

Por se tratar da análise de um dado que descreve a ação coletiva da escola, colocase compreender que o Conselho de Ciclo, enquanto espaço coletivo poderia ser favorecedor de encaminhamentos que visassem a superação do que está instituído na escola, pois como declara Bernardes:

É por meio do trabalho coletivo na escola, do processo de estudo compartilhado, da luta de classe e da representatividade dos interesses educacionais na sociedade letrada que o educador assume níveis cada vez mais claros e mais desenvolvidos da consciência sobre o seu lugar social como representante de uma classe de trabalhadores que detém a possibilidade de transformação da sociedade por meio do desenvolvimento da consciência dos indivíduos com que se relaciona no seu contexto de trabalho [...]. (BERNARDES, 2009, p. 241)

No entanto, a partir do relato enquanto PAEI coloca-se mais um desafio para o exercício da assessoria, pois se clarifica a necessidade de estudo por parte de todos os 
envolvidos de maneira que em conformidade com a autora, pudessem assumir níveis mais claros e desenvolvidos sobre sua função social.

Dessa forma, o relato da assessoria também evidencia outro limite de atuação frente a esta necessidade mapeada junto ao grupo de professores, ASI e equipe diretiva, pois nas escolas sendo professora assessora de educação inclusiva, tinha que atender a todos os professores dos alunos com deficiência e, diante da imediaticidade das necessidades, entendia enquanto possibilidade, problematizar o contexto de sala de aula como um todo somente com a professora eleita para a realização desta pesquisa.

$\mathrm{Na}$ realidade concreta da cotidianidade escolar, outro limite enfrentado pela assessoria, era viabilizar o volume de trabalho. Clarificando esse processo coloca-se que, na busca por atender todas as unidades escolares (profissionais da educação e alunos) uma agenda semanal era organizada pelas professoras assessoras de educação inclusiva. Nessa agenda, a assessoria distribuía as demandas da semana e, prioritariamente, eram marcados encontros com as professoras que tinham alunos com deficiências graves, visto a necessidade da parceria com os profissionais do CADE, ampliar-se. Nos demais dias da semana, distribuía-se o tempo procurando atender os professores dos demais alunos com deficiências menos comprometedoras, seus familiares e também se buscava informações desses, sobre os atendimentos realizados com os profissionais das áreas clínica e terapêutica.

Nesse movimento de análise, a agenda semanal evidencia limites de atuação da professora assessora, quando indica a necessidade de encontros com todos os profissionais das diferentes unidades que assessorava em diferentes horários além da necessidade de atendimento aos diferentes segmentos: escola, família e atendimento clínico e terapêutico. Para clarificação da análise desta categoria, tal agenda ${ }^{10}$ é apresentada:

\begin{tabular}{|c|c|c|c|c|}
\hline $2^{a}$ feira- $7 /$ fev & $8 /$ fev & feira-9/fev & ra- 10/fev & $1 /$ fev- \\
\hline $\begin{array}{l}\text { Manhã: } \\
\text { EMEIEF A } \\
\text { Organizando o } \\
\text { horário com a } \\
\text { Agente Social } \\
\text { de Inclusão. } \\
\text { Verificando as } \\
\text { listas dos } \\
\text { alunos; } \\
\text { Avaliando as } \\
\text { demandas da } \\
\text { escola }\end{array}$ & $\begin{array}{l}\text { Manhã: EMEIEF } \\
\text { C } \\
\text { Conversando com a } \\
\text { equipe sobre a } \\
\text { demanda da escola } \\
\text { e sobre } \\
\text { organização a dos } \\
\text { horários da Agente } \\
\text { Social de Inclusão; } \\
\text { Trocando } \\
\text { informações com o } \\
\text { professor }\end{array}$ & $\begin{array}{l}\text { Manhã: Creche } \\
\text { Trocando } \\
\text { informações com a } \\
\text { professora sobre a } \\
\text { rotina da creche; } \\
\text { Orientações e busca } \\
\text { de informações junto } \\
\text { a mãe do aluno com } \\
\text { Sindrome de Down } \\
\text { que tem restrições } \\
\text { médicas alimentares } \\
\text { e que foi transferido }\end{array}$ & $\begin{array}{l}\text { Manhã: } \\
\text { (Fórum permanente de } \\
\text { Educação inclusiva) } \\
\text { Representando } \\
\text { município de Santo } \\
\text { André no encontro dos } \\
\text { membros do fórum } \\
\text { com os município que } \\
\text { fazem parte do ABC } \\
\text { Paulista (início das } \\
\text { discussões da } \\
\text { organização sobre os }\end{array}$ & $\begin{array}{l}\text { Manhã: EMEIEF } \\
\text { A } \\
\text { Trocando } \\
\text { informações com a } \\
\text { secretária da escola } \\
\text { e com a vice } \\
\text { diretora sobre a lista } \\
\text { de alunos } \\
\text { acompanhados e } \\
\text { sobre a necessidade } \\
\text { de revisão no caso } \\
\text { do aluno promovido }\end{array}$ \\
\hline
\end{tabular}

\footnotetext{
${ }^{10}$ Para preservação das identidades, nos diferentes instrumentos de dados, usam-se nomes e ou códigos de forma a garantir o anonimato das escolas e dos sujeitos participantes da pesquisa.
} 


\begin{tabular}{|c|c|c|c|c|}
\hline 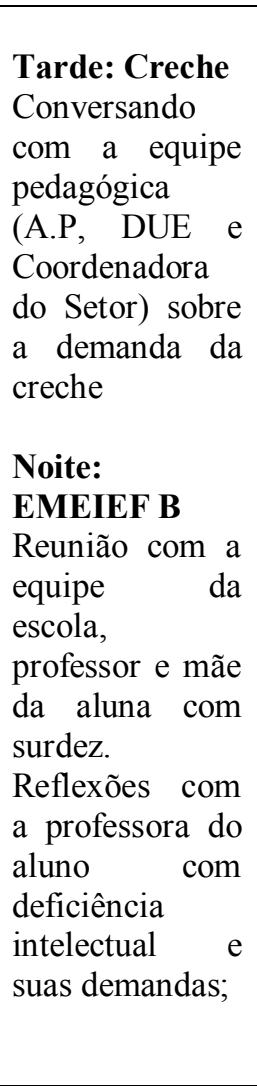 & 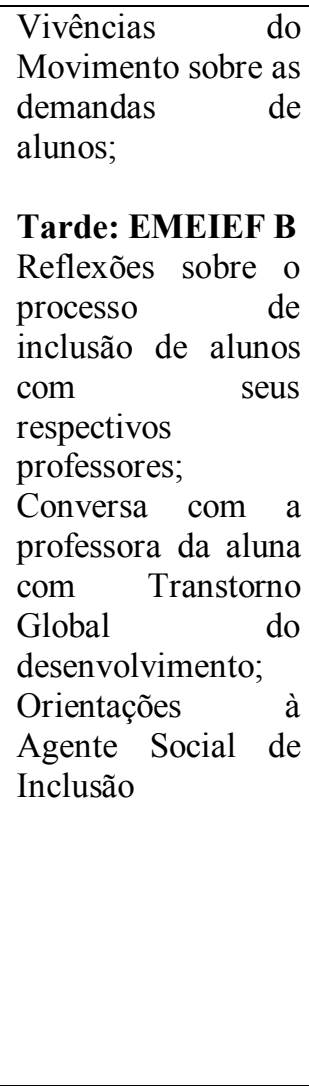 & 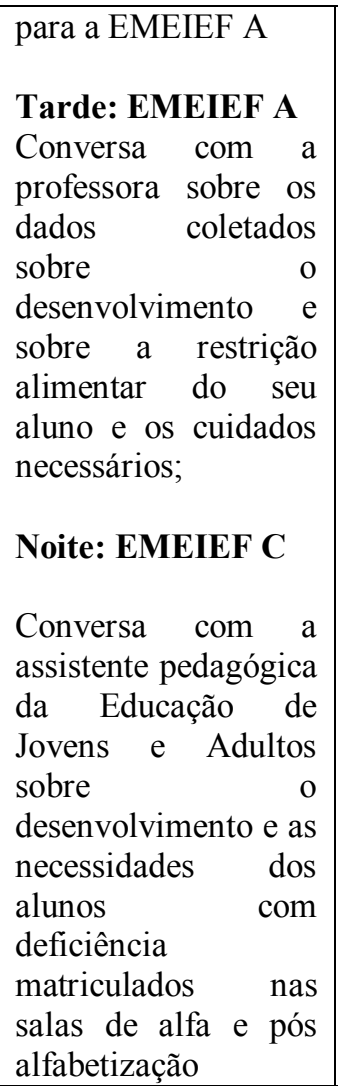 & $\begin{array}{l}\text { encontros seguintes) } \\
\text { Tarde: EMEIEF C } \\
\text { Conversando com as } \\
\text { professoras do período } \\
\text { da tarde e com a } \\
\text { assistente pedagógica } \\
\text { sobre o } \\
\text { desenvolvimento dos } \\
\text { alunos com } \\
\text { deficiência; } \\
\text { Noite: EMEIEF C } \\
\text { Atuando na Educação } \\
\text { de Jovens e Adultos; } \\
\text { conversa com as } \\
\text { professoras desta } \\
\text { modalidade de ensino. } \\
\text { Conversa com a } \\
\text { família do aluno do } \\
\text { período da tarde sobre } \\
\text { o seu processo de } \\
\text { inclusão e sobre } \\
\text { encaminhamento para } \\
\text { avaliação na Fundação } \\
\text { Santo André }\end{array}$ & $\begin{array}{l}\text { Tarde: EMEIEF C } \\
\text { Trocando } \\
\text { informações com a } \\
\text { assistente } \\
\text { pedagógica e com a } \\
\text { professora do aluno } \\
\text { cadeirante: } \\
\text { organização do } \\
\text { mobiliário do } \\
\text { mesmo. Trocas de } \\
\text { informações com a } \\
\text { Agente Social de } \\
\text { Inclusão, assistente } \\
\text { pedagógica e } \\
\text { diretora da escola. }\end{array}$ \\
\hline & & $7 \mathrm{~h} 00$ & $8 \mathrm{~h} 00$ às $12 \mathrm{~h} 00$ & \\
\hline 101000 & $15 n 00$ as 20 nou & $18 \mathrm{~h} 00$ às $20 \mathrm{~h} 30$ & & ás $17 \mathrm{~h} 00$ \\
\hline & & & $3 \mathrm{~h}$ & \\
\hline
\end{tabular}

Quadro 03: Agenda semanal da PAEI

Além da busca por atender a todas as escolas e diferentes segmentos, baseada na agenda semanal, é necessário colocar que ao adentrar a escola, deparava-me com outro limite: equacionar o tempo para direcionar atenção a todos os professores e sujeitos envolvidos com o processo de desenvolvimento dos alunos com deficiência, pois como já indicado, em cada escola, uma média de cinco professores por período aguardam o atendimento da assessoria.

No interior dessa reflexão, cabe colocar que um dos grandes desafios posto a professora assessora de educação inclusiva (PAEI) é superar o imediatismo desenfreado que impede a articulação e continuidade das ações dessa com todos os envolvidos no processo.

A categoria da imediaticidade das necessidades na realidade concreta expressa a rapidez com que fluem os acontecimentos em torno dos alunos considerados com necessidades educacionais especiais, sendo eles com ou sem deficiência. Recoloca-se que essa imediaticidade nem sempre possibilita estudos e reflexões das equipes escolares sobre o processo de desenvolvimento dos mesmos a partir dos aspectos pedagógicos, culturais, econômicos e político. 
Nessa direção, Koche (2010) colabora afirmando que usualmente o homem interpreta a si mesmo a partir do senso comum, também denominado como conhecimento empírico. Segundo o autor:

[...] esse conhecimento surge como conseqüência da necessidade de resolver problemas imediatos, que aparecem na vida prática e decorrem do contato direto com os fatos e fenômenos que vão acontecendo no dia a dia, percebidos principalmente através da percepção sensorial. (KOCHE, 2010, p. 24)

Em concordância com o mesmo, compreende-se que diante do limite para o exercício da assessoria nesta categoria, as condições declaradas pela organização das agendas semanais conduzem o professor assessor de educação inclusiva à realização das ações de forma espontânea e instintiva e isto se dá, pois segundo Patto (2005, p. 11), “por despreparo ou por má-fé, os que governam insistem na tecla das soluções técnicas, investem nas máquinas em detrimento das pessoas [...]" fato que impossibilita análise para além da aparência dos fenômenos que se apresentam no cotidiano da educação inclusiva.

Na busca por apontar as possibilidades de atuação nesta categoria, destaca-se um trecho do registro realizado na EMEIEF C, pois o mesmo indica que ao adentrar a unidade escolar enquanto PAEI "pude dar atenção à ASI (agente social de inclusão) que se mostra incomodada e fragilizada, pois percebe as dificuldades que os professores têm para lidar com os alunos com deficiência”.

Dessa forma entende-se que diante de uma agenda semanal que sobrecarrega a PAEI, há poucas possibilidades de efetiva atuação. Junto à ASI, coloca-se que em raros momentos a assessoria consegue propor estudo e análise sobre o processo de desenvolvimento dos alunos que são acompanhados por ela. A mesma, imersa na imediaticidade do processo, torna-se uma mera executora de tarefas enquanto cuidadora. Diante do dado apresentado a partir do relato enquanto PAEI uma possibilidade evidenciada é a de oferecer escuta atenciosa àqueles que estão envolvidos diretamente com os alunos que apresentam necessidades educacionais especiais, no caso deste relato, à agente social de inclusão.

Ainda sobre a possibilidade de oportunizar escuta atenciosa, bem como sobre os limites encontrados para o avanço das ações em parceria com a professora assessorada segue depoimento:

O trabalho da assessora foi de suma importância no decorrer deste ano com as inclusões da minha turma [...] me deu suporte, me acolheu nos momentos mais dificeis, me orientou na retomada de algumas práticas, sugeriu e comemorou comigo várias conquistas que conseguimos ao final deste período. Em vários momentos 
observei seu 'sofrimento' em não poder assessorar com mais tranqüilidade devido à corrida rotina em acompanhar várias escolas ${ }^{11}$. (ANA, 2011, registro escrito)

Esse depoimento reafirma que o exercício da assessoria esbarra na problemática de uma ação que se restringe ao acolhimento dos sujeitos. Essa análise é colocada pois não se trata, evidentemente de negar a importância da escuta atenciosa direcionada aos professores, mas sim de apontar que a excessiva demanda advinda da quantidade de escolas a ser assessorada e da agenda semanal a ser organizada, minimizam a ação educativa da professora assessora. Esta, estando diante de um tempo restrito, não consegue direcionar suas ações na condução de um processo que auxilie os sujeitos da escola à busca pela compreensão acerca dos acontecimentos em torno da educação inclusiva nas suas miltideterminações. Tanamachi colabora ao declarar que:

[...] a escola de um modo geral, não vem se constituindo em um tempo/espaço da construção do conhecimento, mas em ritos de soberania e competitividade, em hábitos e práticas que privilegiam a repetição e a rotina, que levam a sensação de impotência na criação de alternativas para as demandas da comunidade educacional. (TANAMACHI, 2000, p. 8)

Em consonância com esta afirmação, coloca-se que a ação educativa, da professora assessorada, professora assessora e demais sujeitos da escola, permanece no nível da ação reiterativa uma vez que os mesmos não encontram condições adequadas que oportunizem momentos de análise para as demandas apresentadas pelos alunos permanecendo assim na dimensão empírica da ação-reflexão-ação, ou seja, todos permanecem na dimensão da imediaticidade das necessidades na realidade concreta da educação.

\subsubsection{Dimensão Tarefeira na Ação Pedagógica}

Na continuidade, a partir da categoria da dimensão tarefeira na ação pedagógica, analisam-se os dados levantados com a professora assessorada e professora assessora a partir do registro de planejamento das ações de ambas.

Em concordância com Abramowicz (1997), entende-se que a tarefa de ensinar não tem sido fácil, e, desta forma, coloca-se que durante os encontros agendados entre a

\footnotetext{
${ }^{11}$ Depoimento da professora participante da pesquisa retirado de instrumento de avaliação sobre o desempenho do trabalho do CADE enviado à Secretaria de Educação no final do ano letivo de 2011.
} 
professora assessorada e a professora assessora, percebe-se existir poucas condições para a condução de reflexões na direção da busca pela compreensão da ação pedagógica na sua totalidade, pois sabe-se que, frente ao movimento tarefeiro instituído nas escolas, organizar tempo e espaço para análise do processo é desafiador.

Ressalta-se que, estando diante da análise da categoria da dimensão tarefeira, as questões referentes à governança do tempo e espaço se apresentam indicando que estão diretamente relacionadas entre si, impossibilitando a continuidade desta análise sem declarar e apontar o embricamento entre ambas.

Diante disso, é válido declarar que um limite a partir da categoria da dimensão tarefeira manifesta-se quando o tempo de assessoria direcionado à professora, além de restrito, era conturbado pela dinâmica do cotidiano que não contava com espaços oportunos e adequados para o desencadear e avançar das reflexões.

Sobre o tempo restrito (em instrumento de avaliação enviado aos professores pela Secretaria de Educação no final de 2011), a professora participante da pesquisa quando indagada sobre suas expectativas frente à periodicidade da assessoria na escola, avalia que esta se deu de forma a atender parcialmente suas expectativas.

Apresenta-se a seguir este instrumento de avaliação, pois o mesmo legitima a análise em torno dos dados apresentados nesta categoria a partir do posicionamento da professora participante da pesquisa: 


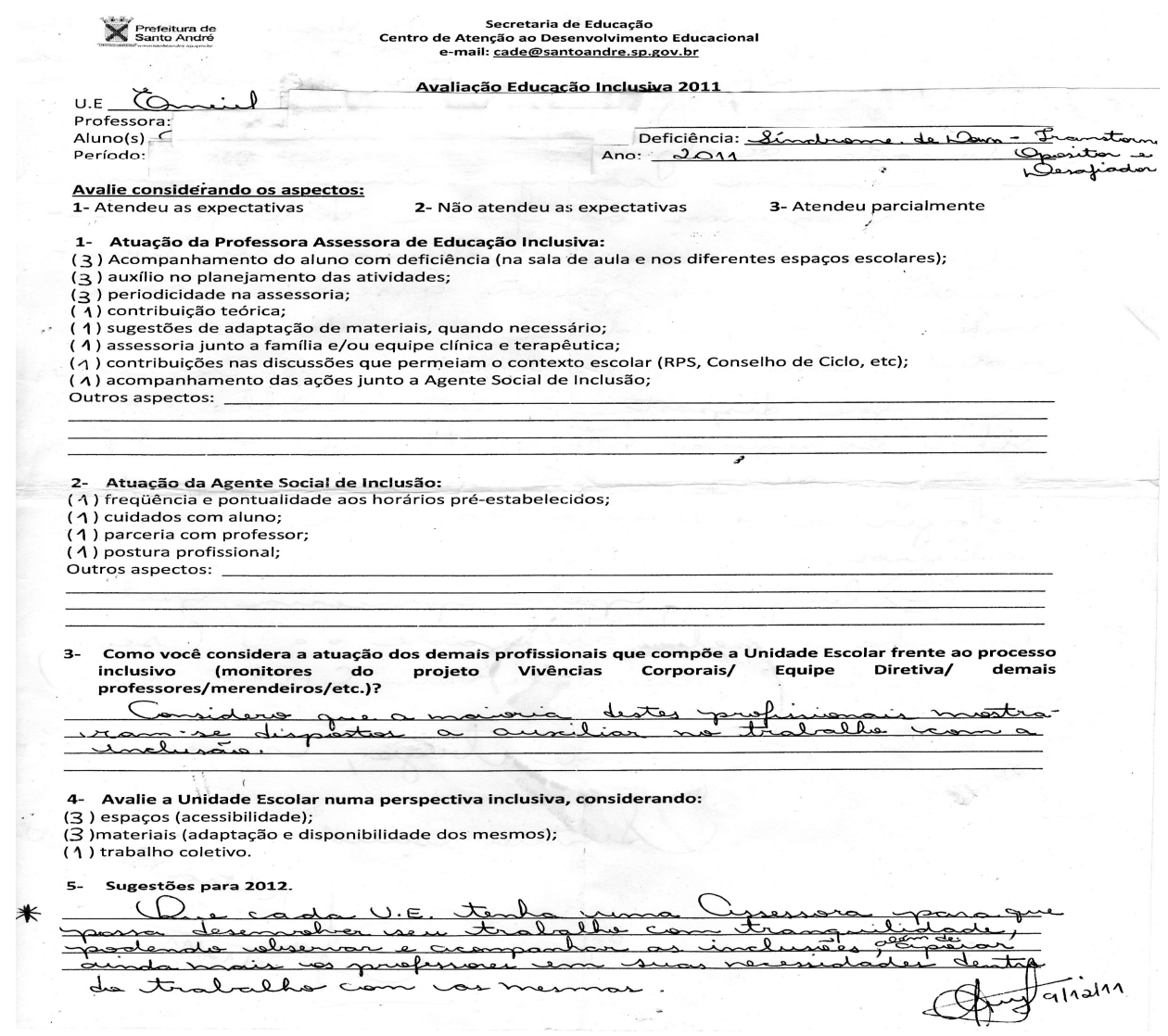

Figura 05: Avaliação sobre o CADE realizada pela professora assessorada.

Nesse instrumento, quando questionado à professora como esta considera a atuação dos profissionais que compõem a unidade frente ao processo educacional inclusivo ela declara que "considero que a maioria destes profissionais mostraram-se dispostos a auxiliar no trabalho com a inclusão".

Ainda no mesmo instrumento de avaliação solicita-se que a professora avalie, para diferentes questões, se: 1- atendeu às expectativas; 2 - não atendeu às expectativas; e 3atendeu parcialmente. Compondo a sua avaliação a mesma opta pelo item três, classificando a periodicidade da assessoria enquanto um atendimento parcial às suas necessidades.

Tal avaliação sinaliza que a professora percebia os limites do acompanhamento da equipe do $\mathrm{CADE}$, pois aquela legitima a disponibilidade da assessoria para atuar junto às demandas dos alunos com necessidades educacionais especiais de sua classe, no entanto, a condição para atuação dessa ação não se efetiva, pelas condições já declaradas.

Cabe colocar que, mesmo entendendo da importância de instituir momentos de estudos com a professora assessorada, esses ficam relegados a segundo plano, uma vez que há na unidade participante da pesquisa, por período, muitos professores e outros sujeitos como, 
por exemplo a ASI, esperando uma oportunidade para problematizarem suas angústias e estranhezas sobre o processo educacional inclusivo.

Frente à quantidade de sujeitos aguardando ser atendidos individualmente, a assessoria não conseguia articular o desencadeamento de ações contínuas junto aos mesmos, pois ao adentrar a escola, diante de tantas tarefas a serem executadas, dirigem-se aos sujeitos que apresentavam-se mais impactados e fragilizados com as manifestações advindas das necessidades apresentadas pelos alunos.

Conforme consta no registro abaixo, articulava-se para planejar a ação educativa junto à professora, mas ao adentrar a unidade, distanciava-se desta ação para poder solucionar problemas emergentes do cotidiano.

Nessa categoria, na tentativa de apresentar um dos limites para o exercício da assessoria e da ação pedagógica da professora assessorada, apresenta-se o registro do planejamento, pois este evidencia a descontinuidade das ações frente às tentativas de ambas.

Abaixo, apresento um instrumento de registro e planejamento realizado no exercício de minha função enquanto professora assessora e pesquisadora, conforme declarado na etapa da ação pedagógica reelaborada.

\begin{tabular}{l} 
Sujeitos: Professora Ana e alunos: João com diagnóstico de Transtorno Funcional Específico (conduta e \\
linguagem) e aluna Clara com diagnóstico de Síndrome de Down \\
\hline Data: 16 de Agosto de 2011 \\
\hline Descrição da necessidade: \\
Oferecer atenção à professora que se mostra muito angustiada e nervosa frente demanda da sala de aula; \\
Outra necessidade que surgiu durante o percurso: conversar com o aluno sobre sua conduta, pois o mesmo \\
constantemente bate nos colegas; \\
Intervir junto aos colegas que foram agredidos no sentido de confortá-los e junto ao aluno no sentido de \\
ajudá-lo a pensar sobre o que faz; causando aos outros tristeza, dor e chateação. \\
\hline $\begin{array}{l}\text { Ação encaminhada pela assessora do CADE: organizar um espaço adequado para poder oferecer escuta a } \\
\text { professora visto que na sala, os alunos estavam muito agitados; }\end{array}$ \\
\hline $\begin{array}{l}\text { Ação a ser realizada pela professora: Nada foi solicitado à professora, pois não houve condições } \\
\text { adequadas para debatermos o problema apresentado pelo aluno; }\end{array}$ \\
\hline Retorno da ação planejada e executada: Não foi possível conversar com a professora reservadamente, \\
pois não havia janelas entre as aulas e também não havia outra pessoa que pudesse assumir a sala para que \\
ela pudesse sair para problematizar as demandas do dia; \\
\hline $\begin{array}{l}\text { Descrição da nova demanda: Reagendar um encontro com a professora para que juntas possamos avaliar a } \\
\text { dinâmica da sala e as demandas dos alunos acompanhados pela assessoria (João e Clara). }\end{array}$
\end{tabular}

Figura 06: Registro do planejamento pedagógico da assessoria no movimento da pesquisa

Nesse planejamento, destaca-se, do item retorno da ação planejada e executada, o fato de que mesmo sendo anteriormente articulada e agendada, a problematização sobre as demandas educativas entre a professora assessora e a professora assessorada não acontece, 
pois, na escola não havia outro sujeito que, atuando em parceria, pudesse conduzir as atividades em sala temporariamente.

Mesmo diante do limite para a atuação, enquanto professora assessora buscava alternativas. Coloca-se, que estando diante da necessidade de propor reflexão à professora, ou mesmo, quando a professora sentia a necessidade de problematização sobre uma determinada situação e procurava a assessoria, ambas, tomadas pelo volume de tarefas e pela dinâmica da escola, muitas vezes, assumindo tom de voz alto para competir com o barulho de muitas vozes, tentávamos dar início a um diálogo problematizador em meio ao pátio, merenda, quadra ou parque da escola, o que nunca se dava com sucesso.

Nesses momentos, evidenciava-se o fato de que a gestão de política pública local, diante das condições anunciadas, não classificava como necessário e importante a implementação de ações articuladas que visassem estudos, reflexões e análises dos processos e encaminhamentos.

Dessa forma, a partir da perspectiva teórica assumida entendia-se a necessidade de criar na realidade da escola possibilidades de atuação, pois, segundo Asbhar (2011, p. 108), tal perspectiva caracteriza-se por um trabalho de campo que busca apreender o dia-a-dia escolar "a partir da interferência planejada do pesquisador, que cria as condições para que as mudanças ocorram”. Nessa objetivação, agenda-se outros encontros com a professora, agora no dia da Reunião Pedagógica Semanal como consta no planejamento da assessoria apresentado abaixo:

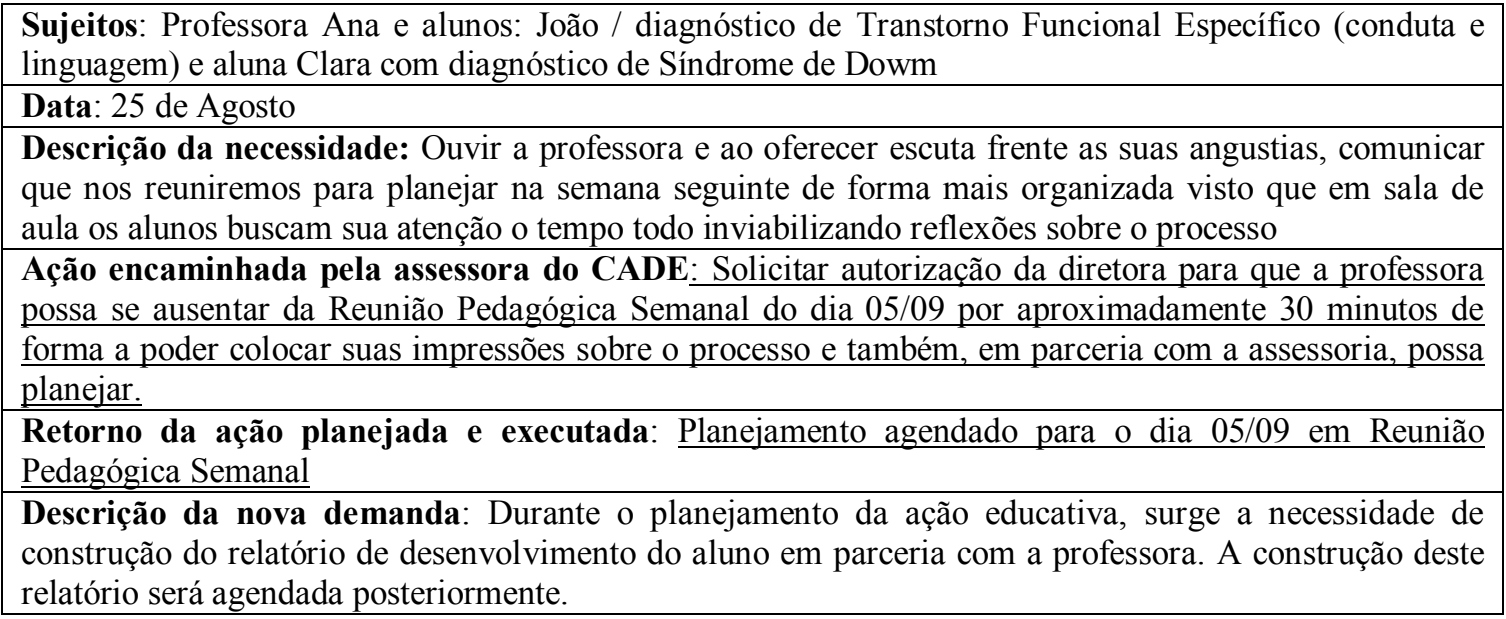

Figura 07: Registro do planejamento pedagógico do assessor no movimento da pesquisa.

Esclarece-se que a reunião pedagógica semanal tem duração de 3 horas, e nesse encontro, todos os professores da unidade comparecem para serem informados a respeito das 
questões administrativas bem como para problematizarem as demandas pedagógicas de todos os seus alunos e para participarem de formações quando estas são solicitadas pelos mesmos ou pela equipe diretiva.

É nesse momento também que o professor pode preencher os diversos instrumentos de controle das ações escolares e de avaliação. Portanto, o pouco tempo destinado para um encontro coletivo de tamanha importância e necessidade, não viabiliza momentos de estudo e de planejamento entre a professora assessora e professora assessorada, sendo necessário solicitar a saída da mesma da reunião de forma a cumprimos com o que foi planejado desde o dia 16 de agosto como consta no planejamento do dia 25 do mesmo mês.

Dentro do limite de atuação, compreende-se que as ações da assessoria permanecem focadas no atendimento da dimensão tarefeira proporcionando poucas condições para o avanço da análise sobre o processo educativo dos alunos. No dado, este fato se apresenta pelas poucas condições de tempo e espaço para o exercício da reflexão tanto por parte da professora assessorada quanto por parte da professora assessora, que, mesmo tendo como objetivo encaminhar e retomar a ação pedagógica planejada, não conseguem, devido a organização da rotina escolar ser caótica, frente a inúmeras demandas a serem executadas por ambas.

Os registros das diferentes datas agendadas na tentativa frustrada de interlocução e problematização entre a professora assessorada e a professora assessora, apontam para um dos maiores desafios do cotidiano da assessoria: a falta de condições para realização de planejamento em parceria com a professora assessorada.

Estando no exercício do cotidiano da escola podem-se citar inúmeros percalços para o exercício da assessoria, mas evidencia-se a impossibilidade de estudos, reflexões e encaminhamentos das necessidades advindas da educação inclusiva, pois essa é a demanda a ser executada no exercício da função de professora assessora. No entanto, pela análise realizada, é necessário afirmar que a política pública local não fornece condições para tal atendimento, portanto, não há motivos que justifique a negação desta realidade, nem mesmo a atitude em acatá-la com passividade, uma vez que os sujeitos que compõe o coletivo da educação inclusiva sentem-se impotentes diante do que está instituído.

Frente à crítica colocada, busca-se em Tanamachi fundamentação teórica ao declarar que:

As questões que hoje se colocam para a Educação escolarizada, construídas com o passar dos anos da Educação brasileira, saltam aos olhos: a questão econômica que confere um caráter de precariedade às práticas educativas, às condições materiais da 
escola e salariais do professor; o modo como se constituem as relações de trabalho no interior das escolas nas quais a hierarquia desapropria em cadeia as iniciativas e as lutas coletivas; a dimensão pedagógica marcada por uma dura rotina, em que o desejo de conhecer não se traduz no interesse de aprender - dificuldade que não concerne somente a crianças e jovens, mas igualmente aos educadores. (TANAMACHI, 2000, p. 8)

Entendendo que a ação pedagógica do professor e do professor assessor deve ser compreendida a partir dos pressupostos da análise histórico-crítica, ao longo deste capítulo procura-se apontar alguns limites e possibilidades a partir da cada categoria de análise, tendo como referência as condições dadas pela gestão de política pública local para o exercício da educação inclusiva.

Na continuidade, situando este estudo entre o pensar e o fazer, propõe-se reflexões acerca das possibilidades de superação ao que está instituído a partir das necessidades desveladas ao longo da pesquisa. 


\section{CONSIDERAÇÕES FINAIS}

A síntese que ora apresenta-se, tem como finalidade indicar o caminho percorrido na busca por algumas respostas à problemática anunciada ao longo da mesma, visando colocar elementos para reflexão acerca dos limites e das possibilidades dadas pela política pública para o exercício do professor e do professor assessor diante do contexto educacional inclusivo.

Problematizando a concepção de educação inclusiva a partir da abordagem teórica em foco, coloca-se que esta foi apresentada como sendo correlata com a concepção de escola para todos, (indistintamente alunos com ou sem deficiência), indicando, portanto, que os processos de "inclusão" e "exclusão" são produções da sociedade de classes. Dessa maneira, este estudo apresentou a concepção de educação e de educação escolar advinda da pedagogia histórico-crítica alinhada à concepção da teoria histórico-cultural, as quais redimensionam as finalidades da educação, bem como a função social da escola e do professor.

Entendendo que este estudo vincula-se necessariamente à compreensão acerca das condições dadas pela gestão de política pública local ao exercício da educação inclusiva, são analisadas as condições dadas às minhas práticas enquanto professora assessora de educação inclusiva no contexto escolar em parceria com as ações educativas dos demais sujeitos que diretamente estão envolvidos no processo.

Nesse alinhamento reflexivo, coloca-se que, durante a realização da pesquisa, acentua-se a necessidade de fazer a crítica às políticas públicas de Educação quando no cotidiano da escola, a partir da teoria adotada, alarga-se a compreensão de que não são somente os alunos com deficiência que lançam desafios ao contexto educacional. Sob este aspecto, recorre-se a Silva (2006, p. 141) ao afirmar que "se os problemas estruturais da educação - como baixos salários, classes superlotadas, formação de professores [...] estivessem minimizados, certamente a inclusão de alunos com necessidades educacionais especiais causaria um impacto menor".

Tal retomada se faz necessária, pois, na abordagem das condições dadas pela gestão da política pública para o exercício da educação inclusiva, ao retornar para o cotidiano da escola, entende-se que os fenômenos da imediaticidade, da dimensão da ação educativa tarefeira e da ausência de tempos e espaços adequados para estudos e debates coletivos minimizam a ação educativa tanto do professor quanto das equipes escolares e do professor assessor frente aos alunos com ou sem deficiência devido às implicações políticas, econômicas e culturais as quais todos são submetidos. 
Buscou-se então criar condições particulares dentro dos limites da assessoria que possibilitassem captar e apontar as necessidades frente ao exercício educacional inclusivo, para que este se desse com mais qualidade e, nessa objetivação, questionando os limites para o exercício da assessoria, busca-se apreender as possibilidades entendendo que, a partir dessa análise, seria possível contribuir indicando as necessidades para a superação do que está instituído.

Na busca pela compreensão acerca dos limites e possibilidades, dados a partir da gestão de política pública, para o exercício da ação pedagógica do professor e do professor assessor no exercício da educação inclusiva, foi necessário relacionar e problematizar a representação do Estado no sistema capitalista e suas implicações frente ao processo educacional a partir de leis que asseguram o direito educacional ao aluno com deficiência e sem deficiência.

Frente às demandas apresentadas pelos alunos com deficiência, a partir da análise sobre as políticas públicas de Estado a nível municipal, entende-se a necessidade da ampliação da oferta do AEE (atendimento educacional especializado), bem como do seu fortalecimento enquanto política pública que visa contribuir com o desenvolvimento do aluno, para que este seja de fato "incluído" no ensino regular a partir da apropriação do conhecimento.

Entende-se, portanto, que o Estado, por intermédio de investimentos financeiros, tem o dever de garantir e acessibilizar esse serviço que, atualmente é oferecido no município de Santo André para uma pequena parcela de alunos distribuídos em 11 salas de recursos multifuncionais, como indicado no $3^{\circ}$ capítulo.

Diante da busca pela superação ao que está instituído no atendimento educacional especializado oferecido pelo município, indica-se também a necessidade de ampliação e valorização do quadro de profissionais com especialização nas diferentes áreas de deficiência, uma vez que se entende que os professores do AEE precisam se integrar pedagogicamente ao coletivo das escolas. Tal necessidade é destacada, pois a partir desse estudo, entende-se que os profissionais da escola não podem perder a dimensão teóricoprática da sua atuação, o que implica afirmar que a intervenção na realidade escolar só pode ser objetivada pelo trabalho coletivo realizado dentro da própria escola. Fato que remete indicar a necessidade da criação de condições, a partir da governança de tempo e espaço, para a consolidação do envolvimento dos professores do AEE com os professores das salas regulares, de modo que, em parceria, desenvolvam um trabalho articulado dentro da própria unidade de ensino. 
Ao problematizar a categoria da imediaticidade das necessidades na realidade concreta, entende-se que, a partir das equipes diretivas, não são oportunizadas e garantidas condições aos professores e demais profissionais da escola, de forma que, a partir de estudos, estes, coletivamente, busquem compreender e planejar ações educativas que sejam adequadas para o atendimento aos alunos com necessidades educacionais especiais.

Frente ao cotidiano, percebe-se que o discurso dos sujeitos é adequado, porém a realidade é adversa quando as condições concretas se esgotam na imediaticidade dos processos. As condições de atuação reflexiva das equipes (diretora, vice e assistente pedagógica, ASI e outros) são reduzidas e, portanto, não são facilitadoras do processo educacional dos alunos com necessidades educacionais especiais.

Os dados desta categoria possibilitam identificar não existir um comprometimento coletivo para o atendimento a tais necessidades. Na imediaticidade das ações, quando surge o desafio frente às demandas dos alunos com necessidades educacionais especiais, os sujeitos coletivamente não conseguem tempos e espaços adequados para, juntos, problematizarem e encaminharem ações educativas favorecedoras ao desenvolvimento dos mesmos. Como já indicado nas agendas, de maneira restrita esse processo restringe-se ao professor do aluno em questão e ao professor assessor.

Diante dessa organização, conclui-se que as condições dadas pela política pública local minimizam o exercício da coletividade, inviabilizando a construção de uma cultura educacional inclusiva. Portanto, coloca-se a necessidade de investimentos formativos e condições adequadas de trabalho, de forma que as equipes diretivas encontrem caminhos na direção de garantir tempos de estudos aos seus professores e demais profissionais que estejam diretamente atuando com os alunos como, por exemplo, a ASI. Entende-se que esses só poderão avançar nas suas hipóteses educativas se conduzidos a problematizarem de forma teórico-prática os problemas individuais trazendo-os para a dimensão coletiva a partir de debates, leituras e reflexões sobre o desenvolvimento pedagógico dos alunos com necessidades educacionais especiais.

Nessa direção, indica-se a necessidade de investimentos da política pública local no que se refere à viabilização de formação destinada às equipes escolares dentro e fora de horário de trabalho, de modo que outras compreensões, olhares e perspectivas sejam sustentadas por elementos teóricos que desvelem o desenvolvimento humano sintetizado a partir do longo e complexo processo histórico-social de apropriações.

Feito esse apontamento, a partir da categoria da dimensão tarefeira na ação pedagógica, surge outra necessidade que será ressaltada e problematizada: a ampliação do 
quadro de professores assessores de educação inclusiva, com formação que promova a este, condições de oferecer atendimento à queixa escolar na sua totalidade, ou seja, condições adequadas para assessorar as equipes e os professores que estão diante dos alunos com necessidades educacionais especiais. A necessidade de ampliação do quadro da assessoria é reafirmada pelo fato de se tratar de uma equipe de profissionais que de maneira propositiva, porém com condições restritas, se coloca em campo na tentativa de contribuir com a construção de uma cultura educacional inclusiva.

Entende-se que, em condições de trabalho adequadas, os professores assessores do CADE poderão atuar de acordo como declarado no Contrato do Grupo ${ }^{12}$, instrumento que indica a importância do professor assessor estar diretamente atuando em parceria com os diferentes segmentos da unidade escolar quando, em um dos trechos deste documento, no objetivo específico, declara que:

[...] os PAEIs deverão favorecer o processo de inclusão dos alunos com deficiência na rede municipal de Santo André buscando qualificar a educação para todos através de assessoria aos professores, acompanhamento aos alunos, promovendo orientações familiares, realizando encaminhamentos para instituições clínicas terapêuticas, oferecendo atendimento educacional especializado em salas de recursos no período contrário da escola e formações para todos os envolvidos neste processo. (Contrato de Grupo, 2009)

Além desse fator, coloca-se que se o professor assessor for direcionado a atuar na totalidade do que se manifesta no cotidiano da educação, poderá efetivamente colaborar com a minimização de um processo excludente, uma vez que sua função é ser formador dos sujeitos que na cotidianidade da educação lidam com as necessidades advindas do processo educacional inclusivo.

Tal reflexão remete colocar que o professor assessor deve sistematicamente atuar junto às equipes e ao professor do aluno com necessidades educacionais especiais quando se entende que estes precisam ser conduzidos, a partir de estudos, a avançarem no processo de consciência acerca da sua função social que assumem.

Entende-se, portanto, que cabe ao professor a busca por elementos no campo da Pedagogia que remeta a reflexões teórico-práticas sobre a sua ação educativa e, nesta perspectiva, coloca-se que, estando diretamente envolvido com os desafios sobre o processo de ensinar e de aprender, esse professor deve se colocar em movimento de estudo, integrandose ao coletivo e, apresentando a esse, elementos concretos sobre o desenvolvimento dos seus alunos a partir de registros sobre o processo de aprendizagem.

$\overline{12}$ Contrato de Grupo segue anexo, como já declarado anteriormente. 
Nesse movimento, entende-se que o professor assessor deve atuar diretamente junto a aquele professor, de forma que ambos, integrados ao coletivo, possam promover caminhos para que os alunos com necessidades educacionais especiais avancem no processo de conhecimento.

Sabe-se que, apesar das condições dadas pela política pública local, a equipe de professores assessores segue sinalizando boa vontade em contribuir com os professores e com o processo de desenvolvimento dos alunos, de forma que estes últimos sejam incluídos no sistema com qualidade. No entanto, entende-se que a qualificação desse processo não se dará somente com boa vontade frente ao que está instituído, mas entende-se serem necessários investimentos formativos a esta equipe do CADE de forma que possam analisar o processo educacional inclusivo para além dos recorrentes diagnósticos que identificam o problema no aluno, seu professor e na escola, desconsiderando o funcionamento e a estrutura do próprio sistema educacional.

Além do que está sendo apontado, ressalta-se a necessidade de ampliação da equipe do $\mathrm{CADE}$, pois estando no cotidiano da educação inclusiva, percebe-se que os professores dos alunos com deficiência buscam a assessoria na tentativa de problematizarem os desafios advindos desta demanda; no entanto, ao se aproximar da realidade deste professor, a assessoria também é solicitada a problematizar e oferecer escuta aos problemas educacionais apresentados pelos alunos com dificuldades de aprendizagem ou transtorno de conduta. Coloca-se, portanto, a necessidade do professor assessor de educação inclusiva acompanhar os processos de desenvolvimento de alunos com deficiência, com dificuldades de aprendizagem e transtornos de conduta.

Aqui cabe outra reflexão, pois tal necessidade se manifesta corroborando com o alargamento das percepções frente ao título proposto para o terceiro capítulo deste estudo, no qual se questiona: Educação Inclusiva ou Educação para Todos?

Esse questionamento se dá propositivamente, pois se entende que o exercício de uma educação inclusiva só se faz coletivamente, buscando entender (a partir de reais condições dadas pela política pública) que é possível atender às diferenças e fazer uma pedagogia que compreenda que a aprendizagem é heterogênea e destoante. Uma pedagogia que, devidamente respaldada pela política pública, não se fragilize diante do outro, do diferente, mas que busque na coletividade compreender a realidade da educação na sua historicidade, nas suas múltiplas determinações, com o objetivo de superação das condições atuais existentes. 
Para tanto, entende-se também da necessidade de articulação entre os tempos e espaços que só serão possíveis se o PAEI tiver um número reduzido de escolas para acompanhar, cabendo indicar que duas unidades seriam coerentes uma vez que esse professor assessor, a partir da formação de uma consciência crítica, teria a possibilidade de ampliar o atendimento aos sujeitos das escolas, alargando assim as possibilidades de percepção coletiva e histórica para os problemas educativos.

Essa condição, dada para o acompanhamento às escolas, ampliaria a qualidade da assessoria, uma vez que distanciaria o professor assessor de um olhar individualizado e imediatista para o processo. Com um número reduzido de unidades para atender, o tempo destinado para estar em cada unidade poderia se dar com mais qualidade uma vez que seria possível a análise dos acontecimentos em torno das demandas da educação inclusiva para além das aparências. O professor assessor teria melhores condições, de juntamente com as equipes, de buscar compreender a realidade escolar para além das produções individuais dos sujeitos, analisando o modo como as ações pedagógicas são produzidas junto ao coletivo, de forma a encontrar condições de superação. Sendo assim, entende-se que o professor assessor precisa ter condições de análise sobre o processo educativo, levando em consideração as reais condições dos alunos e de seus professores, bem como as condições de trabalho das escolas a partir dos determinantes estruturais.

Coloca-se, portanto, enquanto necessidade que, no acompanhamento a queixa escolar, os professores assessores de educação inclusiva devem ter conhecimento profundo acerca das multideterminações presentes entre os sujeitos e o processo educacional, cabendo a ele, em parceria com as equipes diretivas, implantar processos de estudo nas reuniões pedagógicas com o objetivo de analisar a realidade da educação inclusiva numa dimensão teórico-prático que possibilite criar uma nova forma de intervenção na realidade escolar.

Diante da constatação da necessidade de estudos, a partir da categoria da governança do tempo e do espaço, surge outra necessidade que se refere ao tempo designado pela política pública local para a realização das RPSs (reuniões pedagógicas semanais).

A partir desse estudo, cabe indicar a necessidade de ampliação das horas ${ }^{13}$ destinadas às reuniões pedagógicas a partir de investimentos em horas extras pagas aos

\footnotetext{
${ }^{13} \mathrm{Na}$ tentativa de garantir uma aposentadoria equivalente ao exercício de 40 horas semanais de trabalho, o professor da rede municipal de Santo André tem buscado ampliar a carga horária assumindo 10 horas extras semanal na função de professor substituto. Alinhando o interesse do professor às necessidades mapeadas na pesquisa, indica-se que essa ampliação da carga deveria ser garantida pela gestão de política pública com o objetivo de promover o processo de estudo dos seus profissionais.
} 
professores e suas equipes que, estando diretamente envolvidos com os alunos que apresentam necessidades educacionais especiais, possam coletivamente participar de estudos oportunizados pela política pública local a partir de tempos e espaços organizados para tal. Sabe-se que o esforço coletivo deve ser potencializado, pois se entende que este movimento ampliaria os níveis de percepção para a importância do compromisso coletivo diante da educação inclusiva, de modo que os encaminhamentos qualificariam o processo educacional de todos os sujeitos envolvidos. Sobre essa necessidade, busca-se apoio em Bernardes (2012), pois se entende que, para propor caminhos de superação às ações pedagógicas instituídas, é necessário consciência sobre as reais possibilidades de ensino. Portanto, compreende-se que é na dinâmica do trabalho e do estudo que as equipes das escolas poderão avançar no processo de conscientização acerca de suas funções e dos reais limites e possibilidades de superação frente à demanda dos alunos com necessidades educacionais especiais.

Nesse alinhamento, indica-se a necessidade da adoção de um aporte teórico que pressupõe o homem na sua dimensão histórico e cultural, que aponte para uma compreensão de homem que se faz por meio de suas necessidades. Em conformidade com as reflexões apresentadas neste estudo, aponta-se a psicologia histórico-cultural e a pedagogia histórico-crítica enquanto referenciais que vêm indicando caminhos que desvelam a realidade, pois propõe-se análise da mesma para além do cotidiano historicamente instituído, possibilitando assim a apreensão da essência dos fenômenos que se apresentam à escola.

Considera-se, portanto, que a apropriação dos conhecimentos teóricos-práticos por parte dos diretores e vices, assistentes pedagógicos, agentes sociais de inclusão, profissionais do atendimento educacional especializado, professores e professores assessores, seja relevante, pois se sabe que a qualidade do processo educacional inclusivo só ocorrerá quando o ser humano concreto e histórico for tomado como referência desse processo, cabendo questionamentos como sob qual concepção de educação o sistema educacional vigente quer construir a cultura educacional inclusiva, e sob qual percepção vem sendo estruturada.

Entendendo os limites postos a esta pesquisa, indica-se que há muitas perguntas a serem feitas e muitas respostas a serem desveladas em torno da questão da Educação, que mesmo sendo direito de todos, ainda busca se intitular enquanto Educação Inclusiva.

Para finalizar, coloca-se entender que o desencadear de questionamentos a partir desta pesquisa poderá contribuir com a qualidade da ação educativa tanto do professor quanto do seu aluno com necessidades educacionais especiais, e de suas equipes. Para instigar a busca, usa-se uma citação de Facci (2004, p 15), que nos direciona a pensar na importância e responsabilidade que nos cabe na continuidade deste trabalho, ao indicar que "o silêncio não é 
inofensivo. Ao contrário, suas conseqüências são muito penosas e causam muito sofrimento em todos os indivíduos. Não podemos, portanto ficar sem questionar as premissas que são naturalizadas, que são apresentadas como imutáveis". 


\section{REFERÊNCIAS}

ABRAMOWICZ. A. Quem são as crianças multirepetentes? In. ABRAMOWICZ, A; MOLL, J. (Orgs.). Para além do fracasso escolar. Campinas, SP: Papirus, 1997. p.161- 172.

ABREU, L.; CARVALHO, M. F. O professor capacitado para a educação de alunos com deficiência: definições legais sobre a formação de professores. In: CONGRESSO

ESTADUAL PAULISTA SOBRE FORMAÇÃO DE EDUCADORES, 11., Anais..., "Por uma Política Educacional de Formação de professores”. Águas de Lindóia: Unesp, 2011. p. $02-15$.

ANGELLUCI, C. B. A Inclusão de pessoas com necessidades educacionais especiais na rede estadual de São Paulo: a dissimulação da exclusão. In: VIEGAS. L.; ANGELLUCI. C.

(Orgs). Políticas Públicas em Educação: uma análise crítica a partir da psicologia escolar.São Paulo: Casa do Psicólogo, 2011. p. 187-225.

ASBAHR, F. F. S. "Por que aprender isso, professora? Sentido Pessoal e atividade de estudo na Psicologia Histórico - cultural. 2011. 220 p. Tese - Doutorado - Programa de Pós Graduação em Psicologia. Instituto de Psicologia da Universidade de São Paulo, 2011.

AZEVEDO, F. Manifesto dos pioneiros da educação (1932) e dos educadores 1959. Recife: Massangana, 2010.

BATISTA, C. A M. Educação inclusiva: atendimento educacional especializado para a deficiência mental. In BATISTA, C. A. M.; MANTOAN, M. T. E. (Orgs.) Brasília: MEC, SEESP, 2007.

BARROCO, M. S. Psicologia e educação: da inclusão e da exclusão ou da exceção e da regra. Psicologia histórico-cultural. In. MEIRA,M.E.M.; FACCI, M.G. (Orgs.). Psicologia históricocultural. Contribuições para o encontro entre a subjetividade e a educação. São Paulo: Casa do Psicólogo, 2007. p. 158- 184.

BERNARDES, M. E. M. A educação como mediação na teoria histórico-cultural: compromisso ético e político no processo de emancipação humana. Revista psicologia política. vol. 10, nº 20, Jul./Dez, p. 293 - 296. 2010.

Ensino e Aprendizagem como unidade dialética na atividade pedagógica. Revista

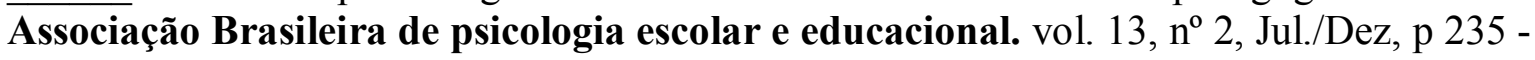
242. 2009.

Mediações simbólicas na atividade pedagógica: Contribuição da teoria HistóricoCultural para o ensino e a aprendizagem. 1ed. Curitiba, PR: CRV, 2012.

BERTOLDO, E. A concepção Marxista de Educação em Leontiev. Revista Eletrônica Arma da Crítica. Ano 2: Número Especial. Dez: p. 189 - 204. 2010

BERTUAL. C. Saúde e Escola: a experiência de Santos. In: vários autores.(Orgs.) Educação especial em debate. São Paulo: Casa do Psicólogo, Conselho Regional de Psicologia, 1997. p. $161-166$.

BOCK. A. M. B. As influências do Barão de Munchausen na Psicologia da Educação. In. MEIRA, M.E.M.; FACCI, M.G. (Orgs.). Psicologia histórico-cultural. Contribuições para o encontro entre a subjetividade e a educação. São Paulo: Casa do Psicólogo, 2007. p.11-33. 
BRASIL. Ministério da Educação. Lei 9394 de 23 de dezembro de 1996. Lei que fixa as Diretrizes e Bases da Educação Nacional. Brasília, 1996.

. O Acesso de Alunos com Deficiência às Escolas e Classes Comuns da Rede Regular. Ministério Público Federal. Brasília: Imprensa oficial, 2004.

Política Nacional de Educação Especial na Perspectiva da Educação Inclusiva. MEC. Brasília: Imprensa oficial, 2008.

Marcos Políticos-Legais da Educação Especial na Perspectiva da Educação Inclusiva / Secretaria de educação especial. Brasília: Imprensa oficial, 2010.

. [Lei Darcy Ribeiro (1996)]. LDB: Lei de Diretrizes e bases da Educação Nacional: lei $\mathbf{n}^{\circ}$ 9394, de 20 de Dezembro de 1996, que estabelece as diretrizes e bases da educação nacional. 5 ed. Brasília: Edição Câmara, 2010.

Constituição da república federativa do Brasil. Texto promulgado em 05 de Outubro de 1988. Brasília: Imprensa Oficial, 2010.

CAGLIARI, L. C. O príncipe que virou sapo. In: PATTO, M.H.S. (Org.). Introdução à psicologia escolar. São Paulo: Casa do Psicólogo, 1997. p.193-224.

CARNEIRO, S. C. A integração de alunos considerados especiais nas redes públicas de ensino. Um olhar Vygotiskiano. In. ABRAMOWICZ, A; MOLL, J. (Orgs.) Para além do fracasso escolar. Campinas, SP: Papirus, 1997. p. 127-144

CROCHÍK, J. L. Aspectos que permitem a Segregação na Escola Pública. In: vários autores. (Orgs.) Educação especial em debate. São Paulo: Casa do Psicólogo, Conselho Regional de Psicologia, 1997. p. 13- 22.

DUARTE, N. Educação escolar, teoria do cotidiano e a escola de Vygotski. Campinas, SP: Autores Associados, 2007.

EIDT, N. M. Discutindo a medicalização brutal em uma sociedade hiperativa. In. MEIRA, M.E.M.; FACCI, M.G. (Orgs.). Psicologia histórico-cultural. Contribuições para o encontro entre a subjetividade e a educação. São Paulo: Casa do Psicólogo, 2007. p. 221- 248.

FACCI, M. G. D. Valorização ou esvaziamento do trabalho do professor?: um estudo crítico-comparativo da teoria do professor reflexivo, do construtivismo e da psicologia vigotiskiana / Campinas, SP: Autores Associados, 2004.

FÁVERO, E. A. G. Aspectos Legais e orientação pedagógica: atendimento educacional especializado. São Paulo: MEC/SEESP, 2007.

FREIRE, P. Educação e mudança. Rio de Janeiro: Paz e Terra, 1983.

Conscientização: teoria e prática da libertação. São Paulo: Centauro, 2001.

FERNANDES, F. Mudanças sociais no Brasil. São Paulo: Difel, 1979.

GADOTTI, M. Educação e compromisso. Campinas: Papirus, 1985.

GARCEZ, L. Da construção de uma Ambiência Inclusiva no Espaço Escolar. 2004. 170 p. Dissertação (Mestrado em Educação) Faculdade de Educação, Universidade de São Paulo, São Paulo, 2004.

GLAT, R.; NOGUEIRA, M. L. L. Políticas educacionais e a formação de professores para a educação inclusiva no Brasil. Revista Integração. Ministério da Educação / Secretaria de Educação Especial. Ano 14, v.24, p. 22-27. 2002. 
HELLER, A. O cotidiano e a história. São Paulo: Paz e Terra, 1985.

KOCHE, J. C. Fundamentos de Metodologia Científica: teoria da ciência e iniciação à pesquisa. José Carlos Koche. 27. Petrópolis, RJ: Ed.Vozes, 2010.

LESSA, S.; TONET, I. Introdução à filosofia de Marx. São Paulo: Expressão Popular, 2008.

LIBÂNEO, J. C. A escola brasileira em face de um dualismo perverso: Escola do conhecimento para os ricos, escola do acolhimento social para os pobres. Revista Educação e Pesquisa. São Paulo, v. 38, n. 1, p. 13-28. 2012.

MACHADO, A. M. Avaliação psicológica na educação: mudanças necessárias. In. MEIRA, M.E.M.; FACCI, M.G. (Orgs.). Psicologia histórico-cultural. Contribuições para o encontro entre a subjetividade e a educação. São Paulo: Casa do Psicólogo, 2007. p. 143-167

MALUF, M. R. Formação e atuação do psicólogo na educação: dinâmica de transformação. In (org) Psicólogo brasileiro: práticas emergentes e desafios para a formação. São Paulo: Casa do Psicólogo, 1994. p. 157 - 200.

MEIRA, M. E. M. Psicologia escolar: pensamento crítico e práticas profissionais. In. TANAMACHI, E. R.; SOUZA, M. P. R.; ROCHA, M. (Orgs). Psicologia e educação: desafios teóricos práticos. São Paulo: Casa do Psicólogo, 2000. p. $35-71$.

MENDES, E. G. Desafios atuais na formação do professor de Educação Especial. Revista Integração. MEC/SEESP. Ano 14, ed. n.24, p.12-17. 2002.

MOYSÉS, M. A. A. A Institucionalização invisível: crianças que não aprendem na escola. Campinas: Mercado das Letras - FAPESP, 2001.

NOSELLA, P. Compromisso político e competência técnica: 20 anos depois. Educ. Soc. vol. 26, n.90, p. 223-238. 2005.

OLIVEIRA, B. A. O Trabalho educativo: reflexões sobre paradigmas e problemas do pensamento pedagógico brasileiro. São Paulo: Autores associados, 1996.

Socialização do saber escolar. São Paulo: Autores Associados, Cortez, 1986.

OLIVEIRA, J. Constituição da República Federativa do Brasil: promulgada em 5 de outubro de 1988.11. ed. São Paulo: Saraiva. 1995.

OMOTE, S. A integração do deficiente: um pseudoproblema? Temas em psicologia. Ribeirão Preto, v. 4, n.2, p.47-52. 1995.

PARO,V. Educação como exercício de poder: crítica ao senso comum em educação. 2. ed. São Paulo: Cortez, 2010.

PATTO. M. H. S. Da psicologia do desprivilegiado à psicologia do oprimido. In: PATTO, M.H.S. (Org.). Introdução à psicologia escolar. 3 ed. São Paulo: Casa do Psicólogo, 1997, p.257-278

Exercícios de indignação. Escritos de educação e psicologia. $1^{\circ}$ ed. São Paulo, Casa do psicólogo, 2005.

Para uma crítica da razão psicométrica. In: Mutações do Cativeiro: escritos de

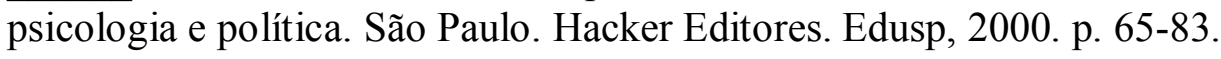

PIMENTA, S. G. Professor reflexivo: construindo uma crítica. In: PIMENTA, S. G.; GHEDIN, E. (Orgs.). Professor reflexivo no Brasil: gênese e crítica de um conceito. São Paulo: Cortez, 2002. p. 17 - 52.

PONCE, A. Educação e luta de classes. São Paulo: Fulgor, 1963. 
POUlANTZAS, N. O Estado, o poder, o socialismo. São Paulo: Paz e Terra, 2000.

PRIETO, R. G. Atendimento escolar de alunos com necessidades educacionais especiais: um olhar sobre as políticas públicas de educação no Brasil. In: ARANTES, V. A. (Org). Inclusão escolar: pontos e contrapontos. São Paulo: Summus, 2006, p.31-73.

ROCHA, M. L. Educação em tempos de tédio: um desafio à micropolítica. In.:

TANAMACHI, E. R.; SOUZA, M. P. R.; ROCHA, M. Psicologia e Educação: desafios teóricos práticos. São Paulo: Casa do psicólogo, 2000. p. 186-207.

ROPOLI, E. A. A Educação especial na perspectiva da inclusão escolar. MEC. SEESP. 2010.

SAES, D. Democracia. São Paulo: Ática, 1987.

SANTO ANDRÉ. Lei orgânica municipal de 02 de abr. de 1990.

Lei Orgânica n ${ }^{\circ 887}$, de 10 de Nov. de 2006. Paulo, 1997.

Estação gente. Educação Inclusiva: Plano 1997. SEFP. Impressão Gráfica FG. São

Estação Gente. Educação Inclusiva. CADE - Centro de Atenção ao

Desenvolvimento Educacional: Direitos Humanos. SEFP. Impressão Gráfica FG. São Paulo, 2000.

. Poéticas das Diferenças. Educação Inclusiva. CADE - Centro de Atenção ao

Desenvolvimento Educacional: Direitos Humanos. SEFP. Impressão Gráfica FG. São Paulo, 2003.

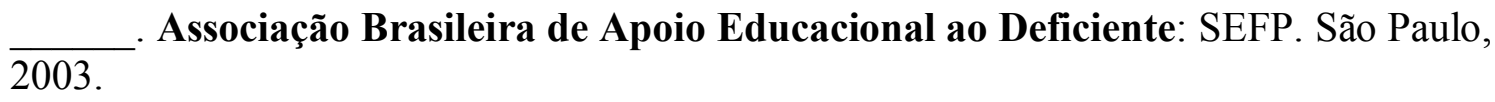

Jornal Informar é Incluir: SEFP. São Paulo, Abr. de 2004.

Jornal Informar é Incluir: SEFP. São Paulo, Dez. de 2005

SAVIANI. N. Saber escolar, currículo e didática: problemas da unidade conteúdo/método no processo pedagógico. 6. ed. revis. Campinas, S. P.: Autores Associados, 2010

SAVIANI, D. A nova lei da educação. Campinas, S. P.: Autores asociados, 2006.

. O legado educacional do "longo século XX" brasileiro. In: SAVIANI, D. (et. al.). O legado educacional do século XX no Brasil. Campinas: SP. Autores Associados, 2004.

Educação: do senso comum à consciência filosófica. 2 ed. São Paulo: Cortez e Autores Associados, 1982.

SERRÃO, M. I. B. Superando a racionalidade técnica na formação: sonho de uma noite de verão. In: PIMENTA, S. G.; GHEDIN, E. (Orgs.). Professor reflexivo no Brasil: gênese e crítica de um conceito. São Paulo: Cortez, 2002, p. 151 - 161.

SILVA, C. L. O papel do diretor na implantação de uma cultura educacional inclusiva a partir de um enfoque sócio-histórico. Dissertação (Mestrado - Programa de Pós Graduação em Psicologia) Instituto de Psicologia, Universidade de São Paulo, São Paulo, 2006

SILVA, J. C. Escola Pública e Classes Sociais em Marx: Alguns apontamentos. Revista HISTBER ON - line, Campinas, nº especial, p. 146 - 155. Abr. 2011. 
SOUZA. M.P.R. A queixa escolar na formação de psicólogos: desafios e perspectivas. In: TANAMACHI, E. R., PROENÇA, M. e ROCHA, M. L. (Orgs). Psicologia e educação: desafios teórico-práticos. São Paulo: Casa do Psicólogo, 2000. p.105-141.

TANAMACHI. E. R. Mediações Teórico-práticas de uma Visão Crítica em Psicologia Escolar. In: TANAMACHI, E. R. , PROENÇA, M.; e ROCHA, M. L. (Orgs) Psicologia e Educação. Desafios teóricos práticos: São Paulo: Casa do psicólogo, 2000. p.73-103.

E. R; ASBHAR, F. S. F.; BERNARDES, M. E. M. Teoria, método e pesquisa na psicologia histórico-cultural. In.: SOUZA, M. P. R.; BEATÓN, G. A.; BRASILEIRO, T. (Orgs.). Interfaces Brasil-Cuba em estudos sobre a psicologia histórico-cultural. São Paulo: Casa do Psicólogo, 2013 (no prelo).

UNESCO. Declaração de Salamanca. Organização das Nações Unidas para a Educação, a Ciência e a Cultura. Salamanca, Espanha, 7 - 10 de junho de 1994. Editado pela Unesco.

Declaração Mundial sobre educação para todos: satisfação das necessidades básicas na aprendizagem. Jomtiem, 1990. Editado pela Unesco, 1998.

VÁSQUEZ, A. S. Filosofia da práxis. Rio de Janeiro: Paz e Terra, 1968.

VIGOTSKI, L. S. A formação social da mente: o desenvolvimento dos processos psicológicos superiores. $6^{\text {a }}$ ed. São Paulo: Martins Fontes, 1998. 
ANEXOS I 
CONTRATO DE GRUPO

2009

\section{CADE- Centro de Atenção ao Desenvolvimento Educacional: Direitos Humanos \\ OBJETIVO GERAL}

O CADE, Centro de Atenção ao Desenvolvimento Educacional da Secretaria da Educação e Formação Profissional, com as equipes diretivas e todos os representantes das UEs, tem por principio a inclusão de todos os alunos na escola e sendo assim busca conjuntamente promover ações que fortaleçam e qualifiquem o processo de Educação para "todos" dentro da Rede Municipal.

\section{OBJETIVOS ESPECÍFICOS}

Favorecer o processo de inclusão dos alunos com deficiência na rede municipal de Santo André buscando qualificar a educação para todos através de assessoria aos professores, acompanhamento aos alunos, promovendo orientações familiares, realizando encaminhamentos para instituições clínicas terapêuticas, oferecendo atendimento educacional especializado em salas de recursos no período contrário da escola e formações para todos os envolvidos neste processo.

\section{ACÕES DOS PROFESSORES DE EDUCACÃO INCLUSIVA:}

Todos os professores assessores de Educação Inclusiva da Rede Municipal de Educação da cidade de Santo André deverão atuar em parceria com os diferentes segmentos e modalidades de ensino que envolve o aluno com deficiência matriculados nas unidades escolares.

\section{ATUACॄÃO JUNTO AOS PROFESSORES:}

- assessorar o professor na busca de estratégias pedagógicas para "todos" viabilizando o envolvimento do aluno com deficiência com seus pares;

- analisar as relações que circulam pela sala junto ao aluno com deficiência (estranheza, fragilidades, medos, resistências...) e problematizá-las na perspectiva de superação;

- acessar o planejamento do professor e contribuir com sugestões de atividades, favorecendo o envolvimento e o desenvolvimento de todos os alunos, numa perspectiva de educação para todos;

- dar apoio ao professor mostrando intervenções e ações diretas junto ao aluno para que esse possa dar seguimento compondo idéias;

- promover reflexões sobre os diferentes modos de aprender e de ensinar;

- indicar e problematizar referências teóricas que subsidiem as ações educativas numa perspectiva formativa

- acolher o professor com o propósito de problematizar as ações educativas, buscando caminhos pedagógicos e repensando estratégias junto ao mesmo. 


\section{ATUACẼ̃O JUNTO AOS ALUNOS:}

- observar e interagir com os alunos com deficiência nas suas relações com a aprendizagem, percebendo suas diferentes formas de aprender e de interagir com o meio;

- viabilizar recursos técnicos e adaptações, em parceria com a professora e o Agente Social de Inclusão;

- encaminhar os alunos com deficiência para realizar avaliações e triagens nas instituições parceiras.

- analisar as relações estabelecidas pelo aluno com deficiência e seus pares nos diferentes tempos e espaços da rotina escolar de forma a contribuir com intervenções propositivas que favoreçam seu desenvolvimento social e pedagógico

\section{ATUAČ̃̃O JUNTO ÀS EQUIPES DIRETIVAS:}

- compartilhar as ações educativas com Diretoras, Assistentes Pedagógicas e Coordenadoras, fortalecendo as parcerias;

- analisar e encaminhar às equipes as solicitações das professoras como aquisição de materiais específicos e ou outras demandas que sejam indicadas pelas mesmas;

- analisar e debater sobre os espaços e a rotina da unidade escolar, buscando qualificar o ensino e facilitar a inclusão do aluno com deficiência;

- problematizar a importância de espaço de discussão e formação em RPSs e RPMs sobre as especificidades e demandas da educação especial na perspectiva da educação inclusiva;

- apresentar as informações sobre os atendimentos terapêuticos realizados pela FSA com os alunos com Transtorno Funcional Específico e analisar junto com as equipes, os encaminhamentos para diagnóstico, devolutivas e intervenções pedagógicas necessárias e possíveis.

\section{ATUACÃO JUNTO AOS FUNCIONÁRIOS DA LIMPEZA E MERENDA:}

- realizar encontros formativos para esclarecer aos funcionários como atuar com os alunos com deficiência valorizando seus potenciais;

- indicar possibilidades de atuação e intervenção de forma a potencializar a autonomia de cada aluno atendido pelos mesmos;

\section{ATUAČ̃̃ JUNTO AOS AGENTES SOCIAIS DE INCLUSÃO:}

- orientar e esclarecer sobre questões relacionadas à inclusão e às deficiências;

- problematizar e esclarecer ações e atribuições do mesmo;

- em parceria com o ASI organizar a rotina de trabalho para assegurar o acompanhamento dos alunos com deficiência, em sala de aula, nos passeios e aulas de vivências corporais;

- problematizar que no exercício de sua função, o ASI deve atuar de forma articulada com os professores assessores de educação inclusiva, professores da sala de aula comum e da sala de recursos multifuncionais, entre outros profissionais no contexto da escola.

- orientar e promover reflexões acerca da importância do estabelecimento de parceria com os professores dos alunos com deficiência. 
- problematizar a atribuição do profissional de apoio clarificando que sua função não é desenvolver atividades educacionais diferenciadas aos alunos com deficiência, e nem responsabilizar-se pelo ensino deste aluno (esta problematização deve se dar com todos os segmentos da unidade)

\section{ATUAĊ̃̃ JUNTO AOS MONITORES DE VIVÊNCIAS CORPORAIS:}

- estabelecer parceria com os monitores de vivências corporais, focando o desenvolvimento do aluno com deficiência e clarificando demandas a partir da especificidade das deficiências

\section{ATUACÃO JUNTO AOS OFINEIROS E ARTE EDUCADORES DOS CESAS:}

- oportunizar orientações sobre características específicas das deficiências e esclarecer questões referentes à inclusão da pessoa com deficiência;

- problematizar com os profissionais do CESA as articulações necessárias entre a unidade escolar e as atividades que podem ser oportunizadas neste espaço, de modo a favorecer o processo de desenvolvimento do aluno e do seu grupo classe

\section{ATUAČ̃̃ JUNTO ÀS FAMÍLIAS:}

- construir parceria objetivando oferecer escuta atenciosa às demandas e necessidades do aluno;

- orientar a família sobre as potencialidades e as necessidades mapeadas junto ao aluno no percurso educativo;

- $\quad$ esclarecer a família sobre a concepção de escola inclusiva bem como a importância da participação de todos envolvidos no processo pedagógico;

- oportunizar e viabilizar devolutiva aos familiares sobre avaliações pedagógicas ou terapêuticas;

- realizar encontros formativos (escola de pais) onde os temas a serem debatidos se direcionem aos interesses e necessidades advindas do processo de desenvolvimento dos alunos no percurso educativo.

\section{ATUACÃO JUNTO ÀS EQUIPES TERAPÊUTICAS:}

- realizar parceria com os terapeutas dos alunos buscando através dessa rede de apoio mapear informações sobre o processo de forma a indicar caminhos aos professores sobre intervenções específicas;

- problematizar com os profissionais envolvidos, ações que se objetivem a qualificar o trabalho pedagógico com os alunos com deficiência em sala de aula.

\section{ATUAČ̃̃O JUNTO AO GRUPO DE PROFESSORES ASSESSORES,} COORDENACC̃̃O E GERÊNCIA DE EDUCACÃO INCLUSIVA:

- participar das reuniões pedagógicas semanais, com o objetivo de fortalecer parcerias com as professoras assessoras dos setores, das salas de recursos, coordenação e gerência de Educação Inclusão;

- estabelecer parceria com outros setores quando da promoção de formações;

- organizar demandas e encaminhamentos necessários;

- organizar e alimentar as listas de alunos acompanhados pela equipe;

- dar devolutivas sobre os materiais e outros instrumentos solicitados pela secretaria; 
- organizar as agendas de atendimento às escolas;

- elaborar os registros sobre o processo de desenvolvimento do aluno;

- participar dos estudos e atividades promovidas pela Secretária de Educação no que se refere ao processo educacional inclusivo. 